UNIVERSIDADE DE BRASÍLIA

CENTRO DE FORMAÇÃO EM RECURSOS HUMANOS EM TRANSPORTES

CRITÉRIOS PARA PREPARAÇÃO DE AEROPORTOS PARA OPERAR COMO HUB

MILTON CAMPOS SIQUEIRA

ORIENTADOR: JOSÉ AUGUSTO ABREU SÁ FORTES

MONOGRAFIA DE ESPECIALIZAÇÃO EM GESTÃO DA AVIAÇÃO CIVIL

PUBLICAÇÃO: E-TA-003A/2008

BRASÍLIA/DF: JUNHO/2008 
UNIVERSIDADE DE BRASÍLIA

CENTRO DE FORMAÇÃO EM RECURSOS HUMANOS EM TRANSPORTES

\section{CRITÉRIOS PARA PREPARAÇÃO DE AEROPORTOS PARA OPERAR COMO HUB}

MILTON CAMPOS SIQUEIRA

MONOGRAFIA DO CURSO DE ESPECIALIZAÇÃO SUBMETIDA AO CENTRO DE FORMAÇÃO DE RECURSOS HUMANOS EM TRANSPORTES DA UNIVERSIDADE DE BRASÍLIA, COMO PARTE DOS REQUESITOS NECESSÁRIOS PARA A OBTENÇÃO DO GRAU DE ESPECIALISTA EM GESTÃO DA AVIAÇÃO CIVIL.

APROVADA POR:

JOSÉ AUGUSTO ABREU SÁ FORTES, PhD (UnB)

(Orientador)

ADYR DA SILVA, PhD (UnB)

(Examinador)

JOAQUIM JOSÉ GUILHERME DE ARAGÃO, PHD (UnB)

(Examinador)

BRASÍLIA/DF, 20 DE JUNHO DE 2008. 


\section{FICHA CATALOGRÁFICA}

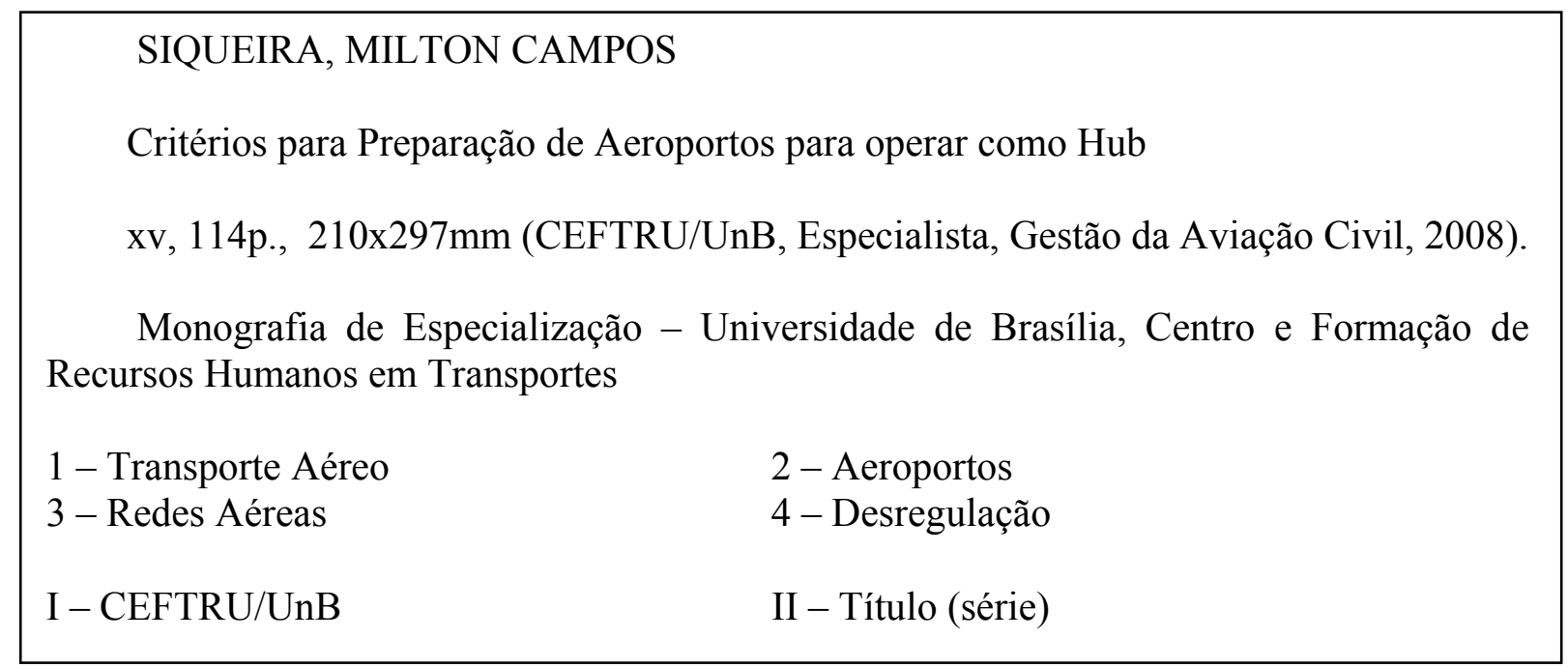

\section{REFERÊNCIA BIBLIOGRÁFICA}

SIQUEIRA, M. C. (2008). Critérios para Preparação de Aeroportos para Operar como Hub. Monografia de Especialização, Centro de Formação de Recursos Humanos em Transportes, Universidade de Brasília, DF, 114p.

\section{CESSÃO DE DIREITOS}

NOME DO AUTOR: Milton Campos Siqueira

TÍTULO DA MONOGRAFIA: Critérios para Preparação de Aeroportos para Operar como Hub

GRAU/ANO: Especialista/2008

É concedida à Universidade de Brasília permissão para reproduzir cópias desta monografia de especialização e para emprestar ou vender tais cópias somente para propósitos acadêmicos e científicos. $\mathrm{O}$ autor reserva outros direitos de publicação e nenhuma parte desta monografia de especialização pode ser reproduzida sem a autorização por escrito do autor.

Milton Campos Siqueira 


\section{AGRADECIMENTO}

A Deus, em primeiro lugar.

À minha esposa, e aos meus filhos Willian e Isabella, que não mediram esforços para suprir minhas ausências no dia a dia, e me deu forças para seguir em frente. E à minha saudosa sogra pelo incentivo.

Ao Ex Superintendente do Aeroporto Internacional Tancredo Neves, Sr Wilson Massa de Souza Bastos, que confiou em meu trabalho que com sua indicação.

Ao Coordenador, Professor Adyr da Silva e ao Orientador, Professor José Augusto pelos preciosos esclarecimentos, contribuindo para o correto direcionamento de todo o Curso e deste trabalho.

Ao amigo, Marcos Willian, pela ajuda nos momentos difíceis.

Por fim, a nossa querida INFRAERO, porque sem ela nada disso seria possível. 


\section{RESUMO}

Neste trabalho, uma pesquisa sobre infra-estrutura aeroportuária com foco em sistema hub foi realizada. Foram apresentadas as características e particularidades dos principais aeroportos existentes em diversos países do mundo, em relação à sua infra-estrutura. Além dos aeroportos estrangeiros, foram analisados os principais aeroportos do Brasil, no qual foram apresentadas as principais características de sua infra-estrutura. As principais companhias aéreas e condições de tráfego aéreo no Brasil foram avaliadas. A definição de hub-and-spoke e os principais parâmetros que caracterizam esse tipo de aeroporto foram estudados. Foram avaliadas todas as vantagens e desvantagens dos aeroportos que utilizam o sistema hub-andspoke. Foi elaborado portanto, a lista de critérios essenciais respeitados para escolha de determinado aeroporto para atuar como hub. Por fim, após análise dos aeroportos brasileiros caracterizados como hub, foi sugerido quais outros aeroportos no Brasil têm potencial para operar no sistema hub and spoke.

Palavras-chave - Hub-and-spoke, infra-estrutura aeroportuária, aeroportos. 


\begin{abstract}
In this Paper a survey about airport infrastructure in hub and spoke technique was basically prepared. The characteristics and peculiarities of the main airports all over the world were introduced. Together with foreign units, major airports in Brazil were also analyzed and the main characteristics of the infrastructure were presented using same goal. The most important airlines and air traffic in Brazil were evaluated. The definition of hub-and-spoke and also the main standard measures which describe this type of airport operation were studied. The benefits and the disadvantages in airports where the hub-and-spoke system is adopted were evaluated. So, it was developed one list with the criterions to be observed and taken in order to choose the airport which is going to act as a hub one. Finally, after the analysis of the Brazilian airports classified as hub, other ones were indicated since they are also potentially able to work in the hub-and-spoke system.
\end{abstract}

Key-words: hub-and-spoke, airport infrastructure, airports. 
Capítulo

$$
1
$$

1.1

1.2

1.3

1.4

1.5

1.6

1.7
INTRODUÇÃO

CONSIDERAÇÕES INICIAIS

PROBLEMA

HIPÓTESE

OBJETIVO

JUSTIFICATIVA

METODOLOGIA DA PESQUISA

ORGANIZAÇÃO DA MONOGRAFIA

REVISÃO BIBLIOGRAFICA

INTRODUÇÃO

BASE TEÓRICA

TRANSPORTE AÉREO DE PASSAGEIROS

EMPRESAS AÉREAS

CLASSIFICAÇÃO DE EMPRESAS AÉREAS

REGULAMENTAÇÃO INTERNACIONAL

REGULAMENTAÇÃO BRASILEIRA

A AVIAÇÃO COMERCIAL

ESTIMULANDO O SISTEMA HUB AND SPOKE

CARACTERIZAÇÃO DE UM AEROPORTO HUB

Características Fundamentais do Hub Internacional

SISTEMATIZAÇÃO DO CONCEITO HUB AND SPOKE

LIGAÇÕES HUB

AUTO DEFINIÇÃO

O NASCIMENTO DE UM HUB

O HUB PERFEITO

CLASSIFICAÇÃO DE AEROPORTOS HUB

HUB AND SPOKE

Cobertura Geográfica

Concentração de Vôos
Página

2

2

3

3

5

5

8

8

9

9

9

10

10

10

11

12

13

13

13

14

15

15

16

20

22 
2.18 REDE OU MALHA AÉREA 24

2.19 REDES LINEAR 26

$2.20 \quad$ VANTAGENS DO SISTEMA HUB 27

2.21 DESVANTAGENS DO SISTEMA HUB 28

2.22 RESPONSABILIDADE CIVIL NO SISTEMA HUB AND 28 SPOKE

$2.23 \quad$ PRINCIPAIS HUBS PELO MUNDO 30

$\begin{array}{llllll}2.24 & \text { GRANDES AEROPORTOS CIVIL PARA OPERAR } & 31\end{array}$ COMO HUB

$\begin{array}{lll}2.24 .1 & \text { Terminais de Passageiros } & 31\end{array}$

2.24.2 Logística de Transporte de Superfície nos Pátios do Hub 32

2.24.3 Carga e Correio Aéreo 33

2.25 POLUIÇÃO DOS AEROPORTOS 33

2.26 AEROPORTOS HUB E SUAS ESTATÍSTICAS 33

$3 \quad$ AEROPORTO HUB AND SPOKE NO BRASIL 35

3.1 INTRODUÇÃO 35

3.2 AEROPORTOS OPERANDO COMO HUB AND SPOKE 35 NO BRASIL

3.2.1 O Aeroporto Internacional de Brasília 35

3.2.1.1 Empresas Aéreas que Operam no Aeroporto e Destinos a 35

Partir de Brasília

3.2.2 O Aeroporto Internacional de São Paulo (Guarulhos) 36

3.2.2.1 Empresas Aéreas que Operam no Aeroporto e Destinos a 37

Partir de Guarulhos

3.2.3 O Aeroporto internacional do Rio de Janeiro (Galeão) 40

3.2.3.1 Empresas Aéreas que Operam no Aeroporto e Destinos a 40 Partir do Galeão

3.2.4 O Aeroporto Internacional Tancredo Neves (Confins) 42

3.2.4.1 Empresas Aéreas que Operam no Aeroporto e Destinos a 43 Partir de Confins

3.2.5 O Aeroporto de São Paulo (Congonhas) 44

3.2.5.1 Empresas Aéreas que Operam no Aeroporto e Destinos a 45 
Partir de Congonhas

3.3 MOVIMENTOS DE PASSAGEIROS DE CONEXÃO

OPERAÇÃO DE AEROPORTO HUB DO PONTO DE VISTA ECONÔMICO

AEROPORTOS COMO AGENTES DE COMPETIÇÃO ENTRE EMPRESAS AÉREAS

DO

CRESCIMENTO ECONÔMICO AÉREAS VÔOS DE UMA EMPRESA AÉREA 
AEROPORTUÁRIA

PRINCIPAIS HUBS BRASILEIROS

6.5.7 Terminais de Passageiros $\quad 83$

$\begin{array}{lll}\text { 6.5.7.1 Linear } & 84\end{array}$

6.5.7.2 Conceitos, Vantagens e Desvantagens em Relação ao HUB $\quad 86$

$\begin{array}{lll}\text { 6.5.8 Nível de Serviço e o Hub } & 87\end{array}$

6.5.9 Modelos Analíticos de Teoria de Filas e o Hub 93

6.5.9.1 Empíricos $\quad 94$

$\begin{array}{lll}\text { 6.5.9.2 } & \text { Simulação } & 97\end{array}$

$\begin{array}{lll}\text { 6.5.9.3 Outros } & 97\end{array}$

6.6 MANUTENÇÃO DO COMPLEXO AEROPORTUÁRIO E 98 O HUB

6.7 SEGURANÇA AEROPORTUÁRIA E AS EXIGÊNCIAS 99 DO HUB

6.7.1 Controle da Segurança da Aviação Civil no Brasil 99

6.8 ACESSIBILIDADE AEROPORTUÁRIA 102

$\begin{array}{lll}\text { 6.8.1 Conceito de Acessibilidade } & 102\end{array}$

6.9 INFRA-ESTRUTURA AERONÁUTICA E O HUB 103

6.9.1 Constituem a Infra-Estrutura Aeronáutica Brasileira de 103 Interesse Para o Hub, os Seguintes Sistemas Segundo o CBA

6.9.2 Controle de Tráfego Aéreo - TWR 104

6.9.3 Navegação Aérea -CSN/ATM - Benefícios ao Hub 105 
Tabela

Página

Tabela 2.1 Definição de Hub And Spoke de Vários Autores

Tabela 2.2 Impacto do Hub no $\mathbf{N}^{\circ}$ de Pares de Cidades Servidas 23

Tabela 2.3 Principais Hubs pelo Mundo 30

Tabela 3.1 Movimentos de Passageiros de Conexão 46

Tabela 6.1 Vantagens e Desvantagens dos Conceitos de TPS 86

$\begin{array}{lll}\text { Tabela 6.2 } & \text { Saguão de Embarque (a) } & 88\end{array}$

$\begin{array}{lll}\text { Tabela 6.3 Saguão de Embarque (b) } & 88\end{array}$

Tabela 6.4 Sala de Pré-Embarque (a) $\quad 88$

Tabela 6.5 Sala de Pré-Embarque (b) 89

Tabela 6.6 Triagem e Despacho de Bagagens $\quad 89$

$\begin{array}{lll}\text { Tabela } 6.7 & \text { Vistoria de Segurança } & 89\end{array}$

$\begin{array}{lll}\text { Tabela 6.8 Vistoria de Passaporte } & 90\end{array}$

Tabela 6.9 Balcões de Vistoria de Passaporte 9

Tabela 6.10 Saguão de Desembarque (a) 90

Tabela 6.11 Saguão de Desembarque (b) 91

Tabela 6.12 Restituição de Bagagens (a) $\quad 91$

Tabela 6.13 Restituição de Bagagens (b) $\quad 91$

$\begin{array}{lll}\text { Tabela 6.14 Alfândega } & 92\end{array}$

Tabela 6.15 Balcão de Alfândega $\quad 92$

$\begin{array}{lll}\text { Tabela 6.16 Sanitários Masculinos } & 92\end{array}$

Tabela 6.17 Sanitários Femininos $\quad 92$

Tabela 6.18 Porcentagem do Fluxo de Passageiros 95

Tabela 6.19 Taxa de Atendimento Modelo Empírico 96 


\section{LISTA DE FIGURAS}

Figura

Página

Figura 2.1 Ligações Ponto a Ponto

Figura 2.2 Ligações Hub and Spoke

Figura 2.3 Esquemas de Redes de Hub and Spoke

Figura 2.4 Sistemas Hipotéticos de Rotas 19

Figura 2.5 Conceito Esquemático da Rede Hub and Spoke 22

Figura 2.6 Esquema de Rede Linear 27

Figura 2.7 Aeroporto Internacional de Frankfurt, Alemanha 31

Figura 2.8 Avião da EasyJet no Aeroporto Internacional de Amsterdã, 32 Holanda

Figura 3.1 Aeroporto Internacional do Rio de Janeiro 40

Figura 3.2 Aeroporto Internacional Tancredo Neves $\quad 42$

Figura 3.3 Planta Baixa do Aeroporto Internacional Tancredo Neves 43

Figura 5.1 $\quad$ Punições por Atraso das Cias Aéreas $\quad 64$

Figura 5.2 Aeroporto de Congonhas $\quad 64$

Figura 6.1 Vista a partir da Torre de Controle do Aeroporto SBGR 69

$\begin{array}{lll}\text { Figura 6.2 Vista de Satélite do Aeroporto } & 77\end{array}$

Figura 6.3 Modelo de Percurso Crítico dos Componentes de Um TPS 98

Figura 6.4 Área de Revista de Bagagem (Denver-EUA) 101

Figura 6.5 Torre de Controle do Aeroporto de Bristol, Inglaterra 105

$\begin{array}{lll}\text { Figura 6.6 } & \text { CNS ATM } & 106\end{array}$ 


\section{LISTA DE SIGLAS E ABREVIAÇÕES}

AC

ACARS

AGENDE

AITN

ANAC

ARS

BDISEG

CBA

CNF

CNS/ATM

CONAC

CPI

COE

COM

CPTM

CSA

DAC

DC

DECEA

ESATA

FAA

FedEx

GIG

GNSS

GPS

GRU

HAM

HPP

IATA

IAD

ICAO

IFALPA
Advisory Circular

Airborne Communication Adressing and Reporting System

Agência de Desenvolvimento de Guarulhos

Aeroporto Internacional Tancredo Neves

Agência Nacional de Aviação Civil

Área Restrita de Segurança

Banco de Dados e Indicadores Socioeconômicos de Guarulhos

Código Brasileiro de Aeronáutica

Código IATA do Aeroporto de Confins

Sistema de Comunicação, Navegação, Vigilância e Gerenciamento de Tráfego Aéreo

Conferência Nacional de Aviação Comercial

Comissão Parlamentar de Inquérito

Centro de Operações de Emergência

Critical Path Model

Companhia Paulista de Trens Metropolitanos

Comissão de Segurança Aeroportuária

Departamento de Aviação Civil

Douglas Company

Departamento de Controle do Espaço Aéreo

Empresa de Serviço Auxiliar de Transporte Aéreo

Federal Aviation Authority

Federal Express Corporation

Código IATA do Aeroporto do Galeão

Global Navigation Satellite System

Global Positioning System

Código IATA do Aeroporto de Guarulhos

Código IATA do Aeroporto de Hamburgo

Hora Prevista de Partida

International Aviation Transportation Association

Código IATA do Aeroporto de Dulles

International Civil Aviation Organization

Federação Internacional de Pilotos de Companhias Aéreas 


\begin{tabular}{|c|c|}
\hline IFR & Instrument Flight Rules \\
\hline ILS & Instrument Landing System \\
\hline ITA & Instituto Tecnológico de Aeronáutica \\
\hline LHR & Código IATA do Aeroporto de Londres \\
\hline MCT & Minnimum Connecting Time \\
\hline MMS & Momento de Maior Solicitação \\
\hline NDB & Non-Directional Beacons \\
\hline PAC & Programa de Aceleração do Crescimento \\
\hline PAN & Plano Aeroviário Nacional \\
\hline PAPI & Precision Approach Path Indicator \\
\hline PSA & Programa de Segurança Aeroportuária \\
\hline PSEA & Programa de Segurança de Empresa Aérea \\
\hline OACI & Organização da Aviação Civil Internacional \\
\hline ORD & Código IATA do Aeroporto de Chicago \\
\hline PF & Polícia Federal \\
\hline PIB & Produto Interno Bruto \\
\hline PPP & Parceria Público Privada \\
\hline RAB & Sistema de Registro Aeronáutico Brasileiro \\
\hline REIL & Runway End Identificator Light \\
\hline RNP & Required Navigation Performance \\
\hline RVSM & Separação Vertical Mínima Reduzida \\
\hline SDU & Código IATA do Aeroporto Santos Dumont \\
\hline STBA & Service Technique des Bases Aériennes \\
\hline ТPHP & Typical Peak Hour Passenger \\
\hline TPS & Terminal de Passageiros \\
\hline TWR & Torre de Controle Aéreo \\
\hline VASIS & Visual Approach Slope Indicator System \\
\hline UNB & Universidade de Brasília \\
\hline VOR & VHF Omnidirectional Range Radio \\
\hline
\end{tabular}




\section{CONSIDERAÇÕES INICIAIS}

A desregulamentação dos serviços aéreos no Brasil promovido pelo Departamento de Aviação Civil - DAC e Agência Nacional de Aviação Civil - ANAC, tem mostrado repercussões sobre as decisões estratégicas das empresas aéreas, em relação à participação no mercado, à quantidade e qualidade de serviços oferecidos e aos preços das tarifas aéreas. Essas modificações estruturais têm conduzido a um enfrentamento de novos desafios, como a liberdade de operação em qualquer ponto do território, o surgimento de novas companhias aéreas e a extinção da maior parte do subsídio para apoiar o transporte aéreo em áreas geográficas regionais (Oliveira, 2007).

As mudanças vivenciadas pelo mercado brasileiro guardam certas semelhanças com fatos ocorridos, nas décadas de 80 e 90, após a liberação das empresas aéreas americanas. No período que sucederam a desregulamentação nos Estados Unidos, novas empresas entraram na indústria do transporte aéreo, as companhias existentes expandiram suas operações, o nível de competição cresceu e houve redução das tarifas. Porém, ao final dos anos 80 , ocorreram várias fusões e falências, havendo indicação de problemas e efeitos decorrentes da desregulamentação (Oliveira, 2007).

Com isso consolidou-se após a desregulamentação o Sistema hub and spoke nos Estados Unidos. Ele constituiu-se em função dos efeitos provocados pela liberação das operações das empresas aéreas, sendo entendido como estratégia das transportadoras para obter vantagens competitivas dentro do mercado que deixou de ser protegido pela regulação. A implantação das operações hub and spoke pelas companhias americanas seguida pelas européias, possibilitou benefícios para os usuários do transporte aéreo. Essa nova situação torna a abordagem sobre o tema visando analisar a aplicabilidade no sistema de transporte aéreo. Essa nova situação torna a brasileiro, especificamente nos critérios de preparação de aeroporto para operar no sistema hub and spoke (Pansin, 2003).

A implantação e preparação de aeroporto para operar no sistema hub and spoke, requer o conhecimento de todos os intervenientes e componentes do sistema de transporte aéreo, de modo a estabelecer requisitos necessários para sua operação, visando gerar os benefícios que 
o hub pode oferecer para todos os usuários, passageiros, cargas, empresas aéreas e instituições envolvidas no referido sistema de transporte (Pansin, 2003).

Identificar quais os critérios fundamentais de infra-estrutura aeroportuária para adequação de um aeroporto ao modelo hub and spoke.

\subsection{HIPÓTESE}

A análise da operação nos aeroportos hub and spoke existentes permite identificar requisitos fundamentais de infra-estrutura necessária para se planejar a adequação dos aeroportos para essa natureza.

\section{$1.4 \quad$ OBJETIVO}

Este trabalho tem como escopo principal à identificação de elementos fundamentais de infraestrutura aeroportuária e econômica para adequação de aeroporto para operar no sistema hub and spoke atendendo à malha aérea brasileira.

\section{5}

\section{JUSTIFICATIVA}

A estratégia para promover a utilização de aeroporto hub é uma forma de maximizar a eficiência do tráfego existente. Hub é conceito de desenvolvimento aeroportuário que estabelece estrutura bem definida de rotas onde o aeroporto hub ou eixo serve como ponto de transferência, para passageiros e carga, que se transportam de diferentes aeroportos, convergindo para depois convergir. Os movimentos nesses aeroportos tipo hub são planejados de forma a fazer coincidir chegadas e partidas em faixas horárias coincidentes, aumentando-se o número de par origem-destino com ligação ao aeroporto base.

Considerando o atual estágio de desregulação do transporte aéreo brasileiro, conhecer os critérios de preparação de um aeroporto para operar no sistema hub and spoke trará subsídios com o objetivo de sugerir para os planejadores e executores a aplicabilidade desses requisitos de preparação, visando minimizar os efeitos negativos que poderão ocorrer no 
desenvolvimento da aviação civil brasileira, tanto para empresas aéreas na reformulação de suas estratégias operacionais, quanto para a administração aeroportuária, onde se prepararem para oferecer as condições necessárias a esse tipo de operação.

\section{6}

\section{METODOLOGIA DE PESQUISA}

Será utilizado para realização da pesquisa o método de abordagem comparativa das condições econômicas dos aeroportos que operam como centralizados e analisar com base nessas características levantadas quais os aeroportos brasileiros poderão assumir a categoria de aeroporto hub. Assim sendo, o estudo é dividido em sete etapas apresentadas a seguir:

A divisão do trabalho foi planejada da seguinte forma:

\section{- Capítulo 2 - Revisão Bibliográfica}

O segundo capítulo aborda os assuntos que serão tratados na primeira etapa que é o estudo da arte fundamentação teórica, a desregulação nos estados unidos, descrevendo como a liberação do mercado do transporte aéreo influenciou a implantação do sistema hub and spoke no território americano, assim como na comunidade européia. abrangem também alguns conceitos de aeroportos que poderão após melhoria da infra-estrutura passar a operar no sistema hub no brasil (pansin, 2003).

\section{- Capítulo 3 - Aeroporto Hub and Spoke no Brasil}

O terceiro capítulo apresenta a caracterização do aeroporto funcionando como hub, enfocando os principais eventos que conduziram à política de flexibilização brasileira, que hoje em dia encontram-se características semelhantes à americana quando surgiu o sistema hub na sua forma plena. uma comparação foi realizada com o funcionamento de grandes hubs internacionais.

\section{- Capítulo 4 - Condições Econômicas para Sistema Hub}

No quinto capítulo, elabora-se uma análise genérica do mercado de transporte aéreo, buscando reconhecer as operações do tipo hub existentes no país, identificando as 
potencialidades do transporte aéreo nacional em relação aos atributos do sistema. neste capitulo será realizado um estudo de caso em aeroporto que tenha suas operações baseadas no sistema hub mostrando as divergências em função da falta de infra-estrutura necessária para eficiência do sistema.

\section{- Capítulo 5 - Atrativo do Sistema Hub para Empresas Aéreas}

Os atrativos obtidos pelas companhias aéreas operadoras do modelo hub são inúmeras. a empresa aérea ganha maior poder de barganha em relação à concorrência. atualmente, o sistema hub and spoke é apontado como "o caminho das pedras" para as empresas low fare/low cost (pansin, 2003).

\section{- Capítulo 6 - Infra-Estrutura de Sistema Hub}

Ao capítulo 4, foi reservado o espaço para a identificação da infra-estrutura necessária ao sistema hub and spoke, tratando dos diversos componentes que atuam no sistema, tanto em relação às redes aéreas quanto às operações aeroportuárias. foram também analisados os fatores econômicos do transporte aéreo vinculados aos hubs.

como resultado desse trabalho será possível estabelecer a identificação dos requisitos de infra-estrutura necessária à operação hub and spoke no sistema de transporte aéreo brasileiro.

Além do alto poder de barganha mediante a concorrência, o hub proporciona outras vantagens como: maior número de ligações; facilidade de transferência de vôos; curto tempo de conexão para vôos de pequenas distâncias; maximização das rotas de maior distância. para a economia local, o hub significa a criação de novos postos trabalho, pois ele gera demanda de serviços que vão desde bancos e lojas até supermercados e salas de descanso (soutelino, 2006).

\section{- Capítulo 7 - Conclusões}

Foram relatadas as conclusões obtidas a respeito dos objetivos propostos, apresentando os elementos fundamentais de infra-estrutura aeroportuária e relacioandos os critérios que devem ser observados para que um aeroporto passe a operar como hub, podendo portanto, sugerir a aplicação desses conceitos nos aeroportos que tem potencial para operar como hub no transporte aéreo brasileiro. 


\section{INTRODUÇÃO}

Logo após a desregulamentação americana, novas empresas se integraram ao serviço de transporte aéreo e as companhias existentes expandiram suas operações, aumentando a oferta e o nível da competição. Como resultado as tarifas foram reduzidas. Porém, a partir de 1985 a indústria começou a se reconcentrar como resultado de diversas fusões e falências, dando inicio a vários problemas de gerenciamento dos impactos provocados pela liberação reguladora.

Outro fator decorrente da desregulamentação do transporte aéreo americano foi a criação do sistema hub and spoke, que tem como concepção básica à concentração de vôos em horários coordenados em um determinado aeroporto, trazendo benefícios operacionais para as empresas aéreas, conseqüentemente criando algum desconforto para os passageiros, porém muitas vantagens (Pansin, 2003).

Algum país da Europa, como a Alemanha, tem localizações geográficas privilegiada, permitindo que o aeroporto local seja portão de entrada da Europa, recebendo vôos dos demais continentes, além de receber grande parte do tráfego dos pequenos países fronteiriços. O perfeito sistema de rotas composto pela integração entre os vôos long haul (vôo de longa distância) e short haul (vôo de pequena distância), permitindo que os vôos short haul sirvam de alimentadores para os vôos long haul e vice-versa..

De acordo com as recomendações estabelecidas na V CONAC, realizada em novembro de 1991, definiu diretrizes para orientar a ação do seu então órgão executivo, o DAC, sucedido pela (reguladora) ANAC, no sentido de proceder a uma redução progressiva da regulamentação existente, denominada de política de flexibilização do transporte aéreo brasileiro (Grossi, 2000).

Em razão dessa política de flexibilização, foi adotado o sistema de liberação monitorada das tarifas aéreas nacionais; foi aberto o mercado doméstico para a entrada de novas empresas tendo aumento de $25 \%$ do número de empresas aéreas. 
A flexibilização do transporte aéreo brasileiro inspirou-se mas não copiou a Lei de Desregulamentação das Companhias Aéreas em outubro de 1978 nos Estados Unidos. O mercado de transporte aéreo norte-americano objetivou a retirada de toda a regulamentação econômica, representando reflexo no setor aéreo do todo o mundo. Observou-se naquele período de que a regulamentação econômica existente estava impedindo a competição no mercado (Pansin, 2003).

A indústria brasileira de transporte aéreo vem passando por grandes mudanças estruturais desde a década de 90. A eliminação das barreiras à entrada de novas companhias e a desregulamentação teve um novo impulso em 1997, criaram uma nova perspectiva de competição para as empresas existentes, obrigando-as a uma grande mudança em sua forma de posicionamento nesse tipo de mercado. O mercado competitivo induziu que a gestão das empresas passasse de uma visão puramente operacional para uma visão de negócios. Nessa nova visão definem-se as rotas com base na demanda por vôos, e só então se verifica o impacto operacional dessa definição, de forma a definir-se a malha efetiva da empresa. A grande desvalorização cambial ocorrida em 1999 revelou a ineficiência de algumas companhias em operar em mercado livre, haja vista os resultados financeiros apresentados naquela ocasião (Coelho, 2001).

Até o início da desregulamentação, o mercado aéreo brasileiro era claramente dividido em companhias internacionais, nacionais e regionais, estas com área geográfica de atuação bem definida, limitando muito a concorrência entre elas. Atualmente, foram eliminadas várias das barreiras à concorrência e a divisão desses grupos não é bem definida.

Em função dessas mudanças, houve grande reflexo na infra-estrutura aeroportuária e no sistema de gerenciamento do espaço aéreo. Com aplicação de hubs em determinados aeroportos em função da demanda de passageiros e interesses das empresas aéreas em operar em determinados aeroportos, caracterizando assim o sistema hub. 
Tabela 2.1 - Definição de Hub andSspoke de Vários Autores

\begin{tabular}{|c|l|}
\hline Autor & \multicolumn{1}{c|}{ Definição } \\
\hline $\begin{array}{c}\text { Button, 1998, } \\
\text { p.20 }\end{array}$ & $\begin{array}{l}\text { No sistema hub-and-spoke, (...) as companhias aéreas geralmente } \\
\text { usam um ou dois grandes aeroportos (...). Vôos são planejados em } \\
\text { bancos nos quais permitem aos passageiros continuar a sua viagem } \\
\text { através de conexões para mais destinos. } \\
\text { In hinb-and-spoke operations, [..] carriers generally use one or more large } \\
\text { airports [..]. Flights are arranged in banks which allow passenger's continuing } \\
\text { on to be consolidated on outbound flights fo further destinations }\end{array}$ \\
\hline Rietveld & $\begin{array}{l}\text { O sistema hub-and-spoke possibilita as empresas aéreas suprirem o } \\
\text { serviço de transporte com muitas combinações de origem e } \\
\text { destinos com alto número de frequiências e preços baixos. }\end{array}$ \\
\&Brons, 2001 & $\begin{array}{l}\text { Hub-and-spoke networks enable carriers to supply transport services to many } \\
\text { combinations of origins and destinations at high frequencies and low costs. }\end{array}$ \\
\hline
\end{tabular}

\begin{tabular}{|c|c|}
\hline Autor & Definição \\
\hline $\begin{array}{l}\text { Bania, Bauer \& } \\
\text { Zlatoper, } 1998, \\
\quad \text { p. } 53\end{array}$ & $\begin{array}{l}\text { "... o sistema hub-and-spoke têm a maioria dos vôos indo para um } \\
\text { aeroporto "hub" proveniente de um aeroporto "aro", concentrando } \\
\text { assim as atividades de uma empresa aérea em poucos lugares. } \\
\text { Viagens entre dois aeroportos "aros", o primeiro vôo é sempre em } \\
\text { direção ao "hub" e então de lá para o destino final." } \\
\text { [..] a hub-and-spoke network has most flights coming to a 'hub" airport } \\
\text { from "rim" airports, concentrating airline activity at a few locations. Travel } \\
\text { between two rim airports involves flying first to the hub and then on to the final } \\
\text { destination. }\end{array}$ \\
\hline $\begin{array}{l}\text { Berry, Carnall } \\
\text { \& Spiller } \\
(1996) \text {, p.1 }\end{array}$ & $\begin{array}{l}\text { [No sistema hub-and-spoke], os passageiros mudam de avião no } \\
\text { aeroporto hub no caminho para destino final. } \\
\text { '[In Hub-and-spoke networks], passengers change planes at a hub airport on the } \\
\text { way to their eventual destination }\end{array}$ \\
\hline $\begin{array}{l}\text { Bootsma, } \\
1997, \text { p.4 }\end{array}$ & $\begin{array}{l}\text { No sistema hub-and-spoke, a rede é desenhada de uma forma em } \\
\text { que as rotas são concentradas em um número de facilidades nas } \\
\text { conexões, chamadas hub. Destinos até o hub são chamados } \\
\text { aros. [..]. Visando maximinizar, as possíveis conexões, a companhia } \\
\text { aérea operadora do hub, usualmente elabora os horários dentro de } \\
\text { um determinado tempo. } \\
\text { [..] in case of hub-and-spoke, the network is designed as such, that routes are } \\
\text { deliberately concentrated at a limited number of connection facilities called hubs. } \\
\text { Destinations from each of these hubs are called spokes. [..]. In order to maximize } \\
\text { these connection possibilities, the hub-carrier usually schedules its flights in a } \\
\text { limited number of time-windows. }\end{array}$ \\
\hline $\begin{array}{c}\text { Goetz \& } \\
\text { Sutton, } 1997\end{array}$ & $\begin{array}{l}\text { Maior centro de conexões de uma companhia aérea. } \\
\text { Major connection complexes for airlines }\end{array}$ \\
\hline $\begin{array}{l}\text { Burghouwt \& } \\
\text { Hakfoort, } \\
2001 \text {, p. } 311\end{array}$ & $\begin{array}{l}\text { O sistema hub-and-spoke é uma combinação das ligações ponto a } \\
\text { ponto com transferência de tráfego em um hub central. } \\
\text { HS-network entail the combination of point-to-point with transfer traffic at a } \\
\text { central hub. }\end{array}$ \\
\hline
\end{tabular}


Na bibliografia brasileira existe obra específica sobre o sistema hub and spoke. Entretanto foi possível pesquisar o tema, via meio eletrônico, nas universidades americanas e européias, organizações internacionais especializadas e governamentais, associações de empresas aéreas e de aeroportos. A investigação estendeu-se também a autores nacionais e estrangeiros reconhecidos no campo do transporte aéreo, mencionados nas referências bibliográficas do estudo, que de algum modo abordavam o assunto.

O material encontrado possibilitou construir uma base conceitual do sistema, englobando os aspectos: operacionais, técnicos e econômicos, bem como incluir suas causas e efeitos. O exame do sistema hub já amadurecido depois de alguns anos de funcionamento nos países desenvolvidos ofereceu também uma visão mais realista das operações associadas ao tema (Lelles, 2001).

A difusão dos conhecimentos ocorrerá considerando a natureza específica desse tema, tratando-se de uma evolução recente dos conceitos, portanto, a base teórica dele pode ser encontrada no escopo desse trabalho. A sistematização a seguir apresenta conhecimentos do estado da arte deste assunto. De acordo com assuntos e objeto de pesquisa, foi apresentada tabela com definições do sistema hub and spoke de vários autores (Lelles, 2001).

TRANSPORTE AÉREO DE PASSAGEIROS

O transporte de passageiros, atingiu níveis de segurança e regularidade que tornaram importante fator de integração intra países e entre países. Com o evento da globalização das atividades comerciais, industriais e turísticas, o avião tornou-se um meio de transporte rápido e seguro, correspondendo aos anseios das atividades dos dias atuais. $\mathrm{O}$ crescimento desse tipo de segmento de mercado (transporte aéreo de passageiros) foi duramente atingido durante os ataques de 11 de setembro nos Estados Unidos, entrando em fase de prejuízos que se mantém até a presente data em algumas empresas. Entretanto nos dias atuais de 2005/2006, pode-se antever um crescimento sustentado na quantidade de passageiros para os próximos dez anos. As vendas de passagens e o movimento de passageiros é diretamente proporcional ao aumento do PIB dos países. Conforme previsões dos organismos internacionais, os países de um modo geral, devem apresentar PIB em crescimento da ordem de (3\%) ao ano nos próximos anos, 
portanto, seguramente haverá aumento significativo da frota mundial de aviões para transporte de passageiros (Mançores, 2004).

No Brasil este crescimento fica bem acima do PIB. Atualmente existe uma polêmica entre os grandes fabricantes sobre a conveniência de se construir enormes aeronaves com capacidade elevada de transporte de passageiros.

\section{$2.4 \quad$ EMPRESAS AÉREAS}

Uma linha aérea, companhia aérea ou empresa aérea, é uma empresa que presta serviços de transporte aéreo de passageiros, mercadorias ou mala postal, de caráter regular ou não. As aeronaves utilizadas para esse fim são comumente conhecidas como aeronaves de carreira.

Várias empresas se unem em alianças aéreas para aumentar sua competitividade com a redução de custos e compartilhamento de vôos.

Estas empresas necessitam da concessão de rotas ou linhas aéreas por parte dos governos dos países nos quais suas aeronaves operam ou sobrevoem.

\section{CLASSIFICAÇÃO DE EMPRESAS AÉREAS}

As empresas aéreas podem ser classificadas como internacionais, nacionais, regionais, domésticas, de baixo custo (low cost), de vôos regulares ou vôos fretados (vôos charter), dependendo da metodologia escolhida.

2.6 REGULAMENTAÇÃO INTERNACIONAL

No plano internacional, o transporte aéreo é conduzido por normas e procedimentos estabelecidos pela ICAO quando relacionados às ações dos estados e pela IATA quando referidos as empresas a ela associadas. 
No Brasil a lei $n^{0} 7.565$, de 19 de dezembro de 1986 criou o Código Brasileiro de Aeronáutica que substituiu o Código Brasileiro do Ar. Hoje está em vigor a Convenção de Montreal, promulgada pelo Decreto $N^{0}$ 5.910, de 27 de setembro de 2006; celebrada em Montreal, em 28 de maio de 1999; aprovada pelo Congresso Nacional por meio do Decreto Legislativo $\mathrm{n}^{\circ}$ 59, de 18 de abril de 2006; entrou em vigor internacional em 4 de novembro de 2003, e para o Brasil, em 18 de julho de 2006, nos termos de seu Artigo 53. Segundo a melhor doutrina, o Código de Defesa do Consumidor, por sua natureza de ordem pública, fulcrada em expressa previsão constitucional, prevalece sobre as Convenções, principalmente no que tange a indenizações por falha na prestação de serviços (Fares, 2007).

\section{8}

\section{A AVIAÇÃO COMERCIAL}

É um conjunto de meios aéreos que inclui as técnicas e as ciências necessárias para a fabricação, manutenção e operação segura de aeronaves destinadas ao transporte de carga e/ou passageiros.

Os primeiros vôos comerciais foram feitos no começo da primeira guerra mundial, nos Estados Unidos da América, e expandiram-se rapidamente após o fim da guerra. Atualmente, existem centenas de linhas aéreas que transportam passageiros e carga em todos os 05 (cinco) continentes.

\section{9}

\section{ESTIMULANDO O SISTEMA HUB AND SPOKE}

A iniciativa do governo americano de estimular a concorrência e expandir o transporte aéreo nos EUA em 1978, através do ato de desregulamentação das empresas aéreas (The Airline Deregulation Act), revolucionou à logística do transporte aéreo americano e conseqüentemente o mundial (Pansin, 2003).

Um dos efeitos dessa medida foi o aumento das rotas hub and spoke e a diminuição das ligações ponto a ponto (point to point). Nas rotas hub and spoke, as empresas aéreas escolhem uma determinada cidade para ser o centro de distribuição dos seus vôos, fazendo com que os 
passageiros mudem de avião no aeroporto selecionado como hub no caminho de seus destinos finais (Lelles, 2001).

Nas figuras abaixo, perceberemos a diferença entre as ligações hub and spoke e ponto a ponto. Nas rotas ponto a ponto, as ligações ocorrem somente entre dois pontos, não havendo uma integração entre os demais pontos. Já nas rotas hub and spoke, todos os pontos estão integrados por um ponto central, no caso da figura, o ponto G. Na prática, a rota hub and spoke significa um aumento da malha de destinos de uma companhia aérea (Lelles, 2001).

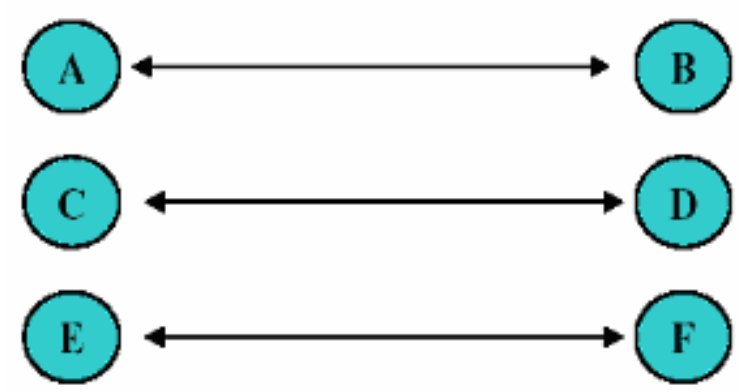

Figura 2.1 - Ligações Ponto a Ponto

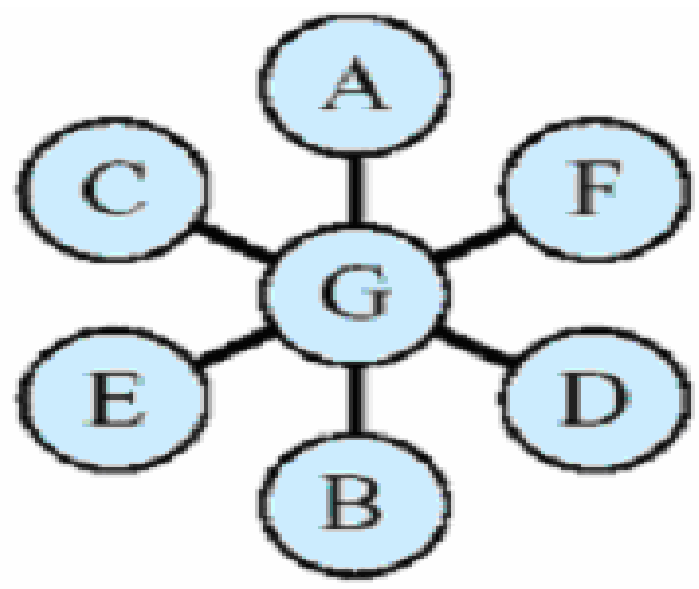

Figura 2.2 - Ligações Hub and Spoke

Um dos principais efeitos da desregulamentação do mercado do transporte aéreo americano, em 1978, foi o aparecimento do sistema hub and spoke, que surgiu como um novo elemento em função do aumento da competitividade entre as empresas aéreas. 
No Brasil isso não foi diferente em razão da flexibilização dada ao sistema de transporte aéreo. Neste segmento, será observados o processo de implantação das operações hubs, com o objetivo de estabelecer a relação de causa e efeito entre ambos, permitindo ao mesmo tempo a caracterização de aeroporto hub e definir a base do conceito do sistema.

A observação do atual estágio da política de flexibilização do mercado brasileiro permitirá correlacionar a realidade brasileira, em especial a identificação da infra-estrutura aeroportuária que apresentam suas operações baseadas no referido sistema (Palhares, 2001).

\subsubsection{Características Fundamentais do Hub Internacional}

Além da posição geográfica e da demanda econômica da região, o hub possui outras características: alto número de freqüências entre os aeroportos aros (spokes), e as companhias principais que operam no hub com vôos long haul (longa distância). Logo, esta companhia absorverá a maior parte dos passageiros provenientes dos vôos long haul de outras empresas aéreas para os vôos domésticos no hub. Evidentemente que possuem tráfego de passageiros provenientes de outras companhias de vôos domésticos. Levará a maior fatia desse tráfego, aquela empresa que tiver associada a uma aliança ou possuir um número maior de code share ou acordos com outras congêneres. Como exemplo de empresas que operam no sistema hub and spoke no mesmo aeroporto, exemplificou os aeroportos de Chicago (ORD) e o de Londres (LHR). Em ambos os aeroportos, o tráfego de passageiros nos vôos nacionais é dividido entre as companhias filiadas às alianças Star Alliance e One World. Em Chicago, há uma divisão entre American Airlines (One World) e United Airlines (Star Alliance), enquanto em Londres, o tráfego é dividido entre British Airways (One World) e British Midland (Star Alliance) (Almeida, 2006).

Outra característica importante é a otimização, pela companhia aérea operadora do hub, das rotas das cidades próximas ou de baixa demanda para o hub, logo, todo o tráfego de passageiros dessas cidades ficará concentrado no hub para que possa ser distribuído para os demais da companhia aérea. 


\subsection{SISTEMATIZAÇÃO DO CONCEITO HUB AND SPOKE}

A iniciativa do governo americano ao estimular a concorrência e expandir o transporte aéreo nos EUA em 1978, através do ato de desregulamentação das empresas aéreas, revolucionou à logística do transporte aéreo americano e conseqüentemente o mundial. Um dos efeitos dessa medida foi o aumento das rotas hub and spoke e a diminuição das ligações ponto a ponto. Nas rotas hub and spoke, as empresas aéreas escolhem uma determinada cidade para ser o centro de distribuição dos seus vôos, fazendo com que os passageiros mudem de avião no aeroporto selecionado como hub no caminho de seus destinos finais.

Nas Fig. 2.1 e 2.2, percebemos a diferença entre as ligações hub and spoke e ponto a ponto. Nas rotas ponto a ponto, as ligações ocorrem somente entre dois pontos, não havendo uma integração entre os demais pontos. Já nas rotas hub and spoke, todos os pontos estão integrados por um ponto central, no caso da figura, o ponto G.

$\mathrm{Na}$ prática, a rota hub and spoke significa um aumento da malha de destinos de uma companhia aérea.

\section{12}

\section{LIGAÇÕES HUB}

Além do aumento da malha aérea, as rotas hub and spoke possibilitaram as companhias aéreas manterem o número de freqüências para o mesmo destino, pois as suas aeronaves passaram a permanecer mais tempo no ar. Um exemplo foi o aumento dos vôos non-stops de Nova Iorque para West Palm Beach, Flórida que passou de cinco para 23 vôos diários depois da desregulamentação, caracterizando assim o sistema hub. O nome hub and spoke pode ser representado como uma roda de bicicleta, no qual os raios formam as rotas spoke, que em direção ao eixo central, formam o hub. Ato que liberou as barreiras governamentais, como desregular as empresas de transporte aéreo, permitindo assim uma maior flexibilidade de rotas; preços; horários, e principalmente a concorrência entre as empresas aéreas. Entrou em vigor em 24 de outubro de 1978 (Oliveira, 2007).

\subsection{3}

AUTO DEFINIÇÃO

O sistema hub and spoke tem a maioria dos vôos indo para um aeroporto hub proveniente de um aeroporto aro, concentrando assim as atividades de uma empresa aérea em poucos lugares. 
Viagens entre dois aeroportos aros, o primeiro vôo é sempre em direção ao hub e então de lá para o destino final o hub and spoke. No sistema hub and spoke, os passageiros mudam de avião no aeroporto hub no caminho para destino final. No sistema hub and spoke, a rede é desenhada de uma forma em que as rotas são concentradas em um número de facilidades nas conexões, chamadas hub. Destinos até o hub são chamados aros. Visando maximizar, as possíveis conexões, a companhia aérea operadora do hub, usualmente elabora os horários dentro de um determinado tempo. Maior centro de conexões de uma companhia aérea. $\mathrm{O}$ sistema hub and spoke é uma combinação das ligações que podem ser ponto a ponto com transferência de tráfego em um hub central.

O sistema low fare não inibe o Hub. Pode não adensá-lo em certas situações. Os hubs no Brasil não foram planejados, mas sim aparecem ao natural. A GOL possui hubs em São Paulo, Gurulhos, Galeão e Brasília (Adir,2008).

\subsection{4 \\ O NASCIMENTO DE UM HUB}

A escolha de um hub por uma companhia aérea engloba uma série de fatores, entre os quais a combinação da demanda econômica e geográfica de uma determinada região com a viabilidade do aumento de suas operações e disponibilização de mais assentos. Segundo a ICAO, através da circular $n^{\circ} 269-A T / 110$, codesharing é uma forma de cooperação entre as empresas aérea, adotada principalmente no plano internacional, com objetivo de se adaptarem às novas tendências de negócios, como globalização, além de aumentar o próprio poder de competição. Na prática, é uma permissão que uma determinada companhia aérea concede a uma segunda companhia para usar sua designação de vôo (seu code, seu vôo, ou o nome da companhia) em um vôo, ou em que duas companhias dividam o mesmo code em um vôo.

É importante ressaltar que, o Hub pode nascer sem codesharing, pois, este apenas o cristaliza como sendo acessório e não essencial como regra. Então, não podemos afirmar que toda companhia aérea possui um hub, mesmo aquelas que operam no sistema ponto a ponto (Adir, 2008). 
Considerando que não há conceituação de hub perfeito, provavelmente o que apresenta característica mais próxima é o Hub do aeroporto de Frankfurt (Alemanha). Este aeroporto é o que melhor traduz o sistema devido à combinação da localização geográfica; o perfeito sistema de rotas e o alto preço na tarifas. O tráfego adicional de passageiros em rotas hub and spoke.

A localização geográfica de Frankfurt em relação à Europa, permite que o aeroporto local seja uns dos portões de entrada da Europa, recebendo vôos dos demais continentes, além de receber grande parte do tráfego dos pequenos países fronteiriços com a Alemanha, permitindo o perfeito sistema de rotas é composto pela integração entre os vôos long haul (vôo de longa distância) e short haul (vôo de pequena distância), permitindo que os vôos short haul sirvam de alimentadores para os vôos long haul e vice-versa.

Outros fatores essenciais do sucesso do sistema hub and spoke em Frankfurt é o predomínio de uma companhia aérea nacional (Lufthansa); permitir o uso de pequenos aviões provenientes dos vôos regionais e áreas disponíveis para uma eventual expansão. Todo hub tem uma empresa. Pode haver mais de um hub em um mesmo aeroporto e isto é fato até no Brasil (Adir,2008).

\subsection{6}

\section{CLASSIFICAÇÃO DE AEROPORTOS HUB}

Segundo a FAA, os hubs estão classificados da seguinte forma:

- $\quad$ Tipo De $H u b \mathrm{~N}^{\circ}$ de Passageiros em Conexões

$\sqrt{ } \quad$ Grande: mais do que 7.102.993 passageiros por ano;

$\sqrt{ } \quad$ Médio: de 1.775 .748 a 7.102 .992 passageiros por ano;

$\sqrt{ }$ Pequeno: de 355.150 a 1.775 .747 passageiros por ano;

$\sqrt{ } \quad$ Non-Hub: com menos de 355.149 passageiros por ano. 
O sistema hub and spoke estrutura-se em duas vertentes principais, a rede de ligações aéreas com os procedimentos associados das transportadoras e as operações aeroportuárias, sendo necessário o entrosamento de ambas as partes para viabilizar o sistema hub. No entanto, com a finalidade de facilitar o entendimento do conceito hub and spoke, optou-se por dividir os componentes que serão tratados em dois itens separados. A primeira parte do capítulo irá focalizar a contribuição das empresas aéreas nas operações do sistema e a segunda definirá o denominado aeroporto hub.

O hub and spoke, consiste em um conjunto de vôos ("banco" ou "onda" de vôos) que pousam durante um intervalo de tempo preciso, para oferecer uma transferência posterior a outro banco de vôos de partidas, maximizando o número de conexões possíveis, mantendo o tempo de em solo dentro de limites curtos e bem definidos. Doganis e Dennis (1989) identificaram dois modelos de sistemas de hub and spoke: as redes "ampulheta" e "hinterlândia". Através de um hub ampulheta, representado a esquerda da Fig. 2.3, os vôos são originados de uma região distante, consolidados no hub e diversificados em direção oposta. Este modelo de configuração está mais adequado para operação de vôos intercontinentais ou transoceânicos, bem como para o tráfego doméstico em países de grandes dimensões territoriais, onde existe a presença de fluxos densos de norte para sul ou de leste para oeste e vice-versa. As linhas alimentadoras de longo curso também se adaptam melhor ao hub tipo ampulheta.

No hub "hinterlândia", mostrado a direita da figura, são operados os vôos de curta distância, utilizando os aeroportos denominados de spokes, localizados em sua área de influência, que servirão de alimentadores do hub que, por sua vez, irá oferecer conexões para novas rotas de médio ou longo cursos. Nesse caso, enquadra-se o tráfego regional ou nacional, dependendo do tamanho do país. 
Ampulheta

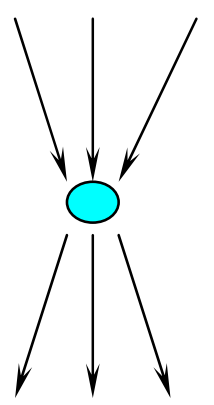

Hinterlândia

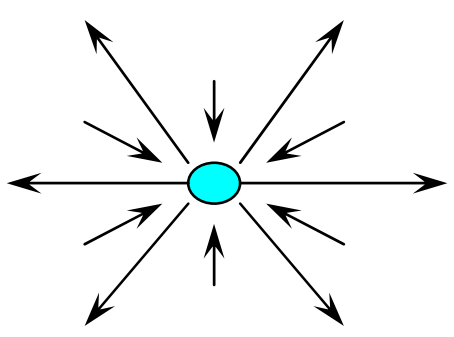

Figura 2.3 - Esquemas de Redes de Hub and Spoke

A operação da rede modelo ampulheta tende a utilizar aeronaves de capacidades similares, na medida em que existe densidade equivalente de tráfego em ambas as direções. Enquanto na hinterlândia, normalmente, são usados equipamentos de portes diferentes: aeronaves menores operando nas ligações entre os aeroportos spokes e o hub e equipamentos de maior porte para transportar o tráfego consolidado partindo do hub para outros destinos distantes ou para outro hub.

Os vôos são afunilados em grupos para o hub de grande porte, onde uma quantidade substancial de passageiros que trocam de aeronaves para completar a sua viagem. A mudança de aeronaves implica uma coordenação de chegadas de um grande número de vôos, em curto espaço de tempo, e posteriores partidas igualmente coordenadas dentro de um intervalo estreito de tempo. Hubs de grande porte podem acomodar mais de sete bancos de vôos por dia, permitindo uma combinação de vôos disponíveis para um determinado destino expandirse consideravelmente.

Neil Bania et al. (1997), elaborando uma classificação das companhias aéreas americanas, descreveu outros tipos de estrutura de rotas, consistindo de quatro sistemas hipotéticos de malha aérea, cada uma servindo a seis aeroportos, denominadas de mono hub, dual hub e dois sistemas difusos, que estão ilustrados na Fig. 2.4 abaixo. Na verdade, as hipóteses são variações das ligações ponto a ponto e hub and spoke.

Na rede mono hub, todos os vôos de uma empresa aérea têm origem ou se destinam a uma única localidade central. Os passageiros com origem no hub $\mathrm{C}$ podem chegar, por ligação direta, a 100\% dos outros aeroportos, enquanto os usuários partindo dos aeroportos A, B, D, E ou $\mathrm{F}$ alcançam diretamente apenas $20 \%$ das outras cidades. 
Uma rede dual hub possui ligações de modo similar, porém existem dois ou mais aeroportos nos quais as operações estão concentradas. Nesse caso, C e D possuem 100\% de linhas diretas para toda a rede e os outros apenas alcançam $40 \%$ da malha, sem escalas.

Segundo os autores, existem diversos tipos possíveis de redes difusas de rotas, variando desde um tipo onde cada aeroporto oferece serviços sem escalas para as unidades aeroportuárias restantes, até um sistema onde o nível de serviços oferecidos vai diminuindo gradativamente de acordo com a possibilidade de conexão do aeroporto. Portanto quanto maior o número de conexões disponíveis, o nível de serviço do aeroporto é mais elevado.

No Sistema Difuso 1, verifica-se que todas as cidades ligam-se entre si, por meio de linhas diretas (100\% de acesso), com um nível de serviço idêntico em qualquer dos mercados, pressupondo a existência de disponibilidade equivalente de conexões em cada aeroporto.

A segunda hipótese de rede difusa comparada com a de mono hub exibe a diferença entre os dois conceitos, linear e hub and spoke, uma vez que na malha hub há uma otimização das ligações, que permite as seis localidades se conectarem por intermédio de um aeroporto central, apesar da oferta menor de serviços. Enquanto o Sistema Difuso 2, com disponibilidade de dois serviços a mais, não atende a todos os aeroportos igualmente. 


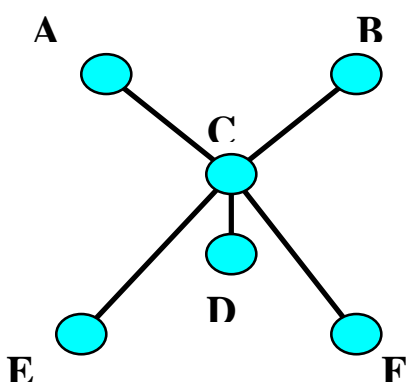

Mono-hub 10 serviços

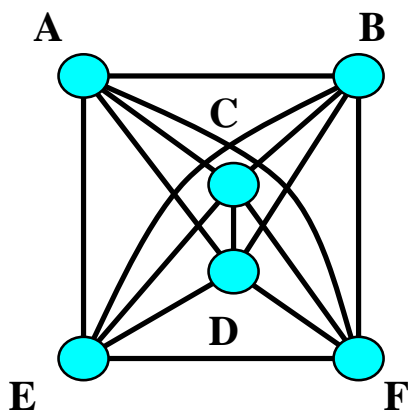

Sistema Difuso 1 30 serviços

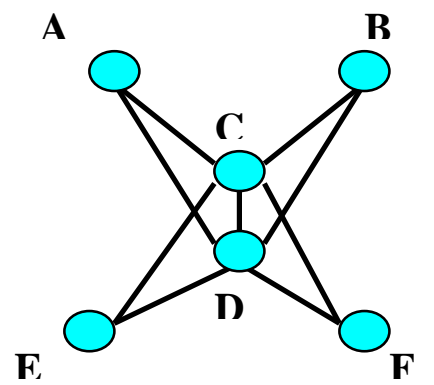

Dual-hub 18 serviços

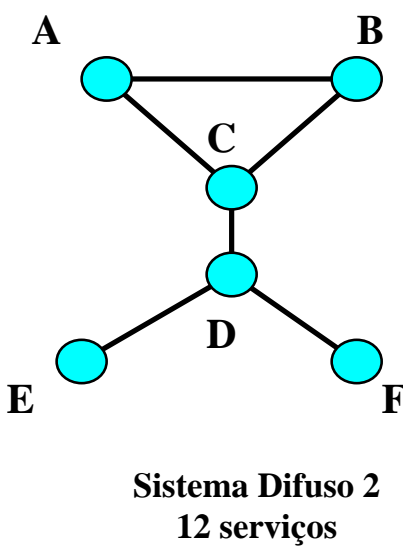

Figura 2.4 - Sistemas Hipotéticos de Rotas

Abstraindo a variável de demanda, o sistema dual hub, operando $60 \%$ dos vôos existentes na rede difusa 1, produz um nível de serviço equivalente, se for levada em conta a possibilidade de maior oferta do número de frequências.

Há disponibilidade na literatura de muitas definições atribuídas ao fenômeno da rede hub, hubbing ou hub and spoke, todas mais ou menos contendo um sentido comum, embora com abordagens ligeiramente diferentes. As definições abaixo indicadas foram selecionadas para esclarecer melhor o conceito:

Hubbing implica em vôos que saem de diferentes aeroportos que são os spokes da rede e chegam ao hub aproximadamente ao mesmo tempo. as aeronaves estão simultaneamente no solo, facilitando desse modo o intercâmbio de passageiros e bagagens durante um período curto de tempo, depois decolam em sucessão rápida de volta em direção dos spokes (Doganis, 1991). 
Uma rede hub and spoke possui a maioria dos vôos chegando ao aeroporto hub, originados dos aeroportos "rim", concentrando as atividades das companhias aéreas em poucas localidades (Cranston, 1996).

Os aeroportos denominados de "rim" são os aeroportos menores que estão localizados a curta distância, na área de influência do aeroporto principal, desempenhando a função de alimentar o hub. Outra nomenclatura utilizada para definir a função do spoke.

As redes hub and spoke tornaram-se uma ferramenta estratégica muito importante para o negócio das ligações aéreas, assim como para o transporte de passageiros e de carga, conforme atestado pelas declarações do Sr. Althen, presidente executivo da Lufthansa Cargo: Uma rede hub é o único meio para uma operação de frete carregar completamente a aeronave e estabelecer uma rede global ao mesmo tempo. para nossos clientes, que são globais, temos que ir para todo o globo e para atendê-los com uma rede global será necessário hubs e parceiros (Noble, 1995).

Hubs são cruciais para o desenvolvimento da carga porque o fretamento não se origina necessariamente dos aeroportos tradicionalmente orientados para passageiros (Gallacher, 1996)

Embora o transporte de carga aérea não seja o objeto central de consideração no presente trabalho, segundo Hamoen (1998), a empresa cargueira pioneira na utilização da rede hub and spoke foi a FedEx, sendo seguidamente adotada por outras empresas cargueiras. Somente mais tarde o sistema hub foi acolhido pelas companhias aéreas no transporte de passageiros.

Após a definição acima da configuração das estruturas de rotas, no item seguinte será focalizado um fator importante, intrínseco da rede hub and spoke, que consiste na utilização do sistema em função das áreas geográficas a serem atendidas.

\subsubsection{Cobertura Geográfica}

Entende-se por cobertura geográfica de uma rede hub a porção territorial onde se localizam as cidades atendidas por uma companhia aérea, por meio de ligações que são conectadas em um determinado aeroporto. 
A partir do conceito do sistema hub and spoke, considera-se a existência de dois tipos de mercado doméstico no transporte aéreo: a rede regional que capta o tráfego local da área de influência de um hub regional, para posteriormente conduzí-lo para outros destinos e a rede nacional com hubs localizados em grandes centros.

$\mathrm{Na}$ teoria, para determinar a cobertura geográfica de uma rede hub que opera o tráfego regional, a primeira etapa consiste no estabelecimento de uma área territorial onde se localizam os pontos que constituem os mercados atendidos. A região pode ser delimitada com base na área de influência econômica polarizada por uma cidade importante como centro de negócios. Pode-se adotar uma divisão geográfica já estabelecida por um órgão governamental como, por exemplo, as regiões ou mesorregiões geográficas brasileiras, desde que haja uma certa coincidência territorial entre a região oficial adotada e a demanda do tráfego aéreo.

Enfim, será necessário estabelecer uma região demarcada e consistente com o mercado.

A segunda etapa constitui o estabelecimento das possíveis ligações entre as cidades abrangidas pela divisão territorial escolhida. Finalmente, calcular a porcentagem de vôos realizados em relação ao total das linhas possíveis, que se conectasse por intermédio de um aeroporto específico. O mesmo processo serve para a rede nacional, com a diferença de tratarse de uma área de superfície mais ampla.

Neil Bania et al (1997) elaboraram uma classificação de empresas aéreas americanas em função do escopo geográfico, escala de operações e tipos de estrutura de rotas. Para determinar o escopo geográfico das companhias, calcularam a percentagem dos vôos, de cada uma, que chegam ou partem dentro de uma mesma ou adjacente divisão do censo americano. Os resultados permitiram apontar as operadoras regionais (Southwest e Alaska Airlines), enquanto que as restantes foram classificadas como nacionais, não por servirem o país inteiro, mas porque atendiam uma porção maior do território americano do que as regionais, ou seja, serviam a mais de uma divisão.

A cobertura geográfica constitui o ponto de partida para a escolha do aeroporto para desempenhar a função de hub na rede. Preferencialmente, a localização desse aeroporto deve ser o mais centralizada possível em relação ao seu mercado, de maneira a encurtar ao máximo 
as distâncias entre os spokes e o hub, ressalvado aqueles que atendam aos requisitos de infraestrutura para apenas operarem como tal.

\subsubsection{Concentração de Vôos}

Para melhor ilustrar o conceito de uma rede hub, a Fig. 2.5 abaixo representa esquematicamente três vôos diretos servindo três pares de cidades (A-B, C-D, E-F), que podem ser combinados para oferecer uma rede tipo hub and spoke, com as ligações operadas através de um hub com a localização central X.

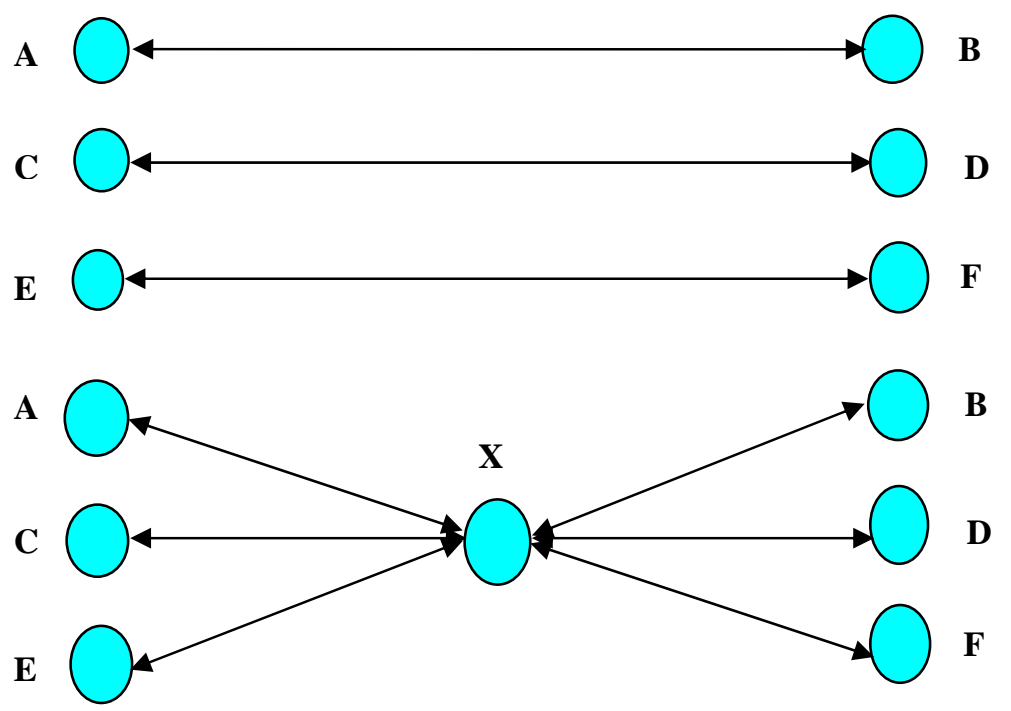

Figura 2.5 - Conceito Esquemático da Rede Hub and Spoke

Se as três ligações entre as cidades forem substituídas por seis serviços diretos de cada um dos seis aeroportos para o hub $\mathrm{X}$, o número de mercados de pares de cidades servidas salta de três para 21. Essa vantagem aumenta em proporção ao quadrado do número de rotas ou spokes operados a partir do hub. Então, se um hub possuir n spokes, o número de linhas diretas é igual a n, ao qual poderão ser adicionadas $n$ (n-1) / 2 de conexões. Um progressivo impacto da introdução de mais ligações por meio de um hub pode ser visto na Tab. 2.2 abaixo. 
Tabela 2.2 - Impacto do Hub no No de Pares de Cidades Servidas

\begin{tabular}{|l|l|l|l|l|l|}
\hline $\begin{array}{c}\text { Aeroportos } \\
\text { Spokes }\end{array}$ & $\begin{array}{c}\text { Mercados } \\
\text { Ligados Via } \\
\text { Hub }\end{array}$ & & $\begin{array}{c}\text { Ligações } \\
\text { Terminando no } \\
\text { Hub }\end{array}$ & & $\begin{array}{c}\text { Pares de } \\
\text { Cidades } \\
\text { Servidas }\end{array}$ \\
\hline $\mathbf{n}$ & $\mathbf{n}(\mathbf{n}-\mathbf{1}) / \mathbf{2}$ & + & $\mathbf{n}$ & $=$ & $\mathbf{n}(\mathbf{n}+\mathbf{1}) / \mathbf{2}$ \\
\hline 2 & 1 & + & 2 & $=$ & 3 \\
\hline 6 & 15 & + & 6 & $=$ & 21 \\
\hline 10 & 45 & + & 10 & $=$ & 1.275 \\
\hline 50 & 1.225 & + & 50 & & \\
\hline
\end{tabular}

Canalizando as ligações que seriam um amplo número de fluxos entre pares de cidades separadas e esparsas para um serviço convergente via hub, a densidade do tráfego em um spoke particular poderia estabelecer operações com um maior número de freqüências. Em outras palavras, o tráfego adicional gerado pelas conexões poderia permitir à empresa aérea operar um maior número de vôos.

Assim, as freqüências de serviços possíveis conectada via hub unindo dois spokes distantes, que possuíssem um tráfego rarefeito entre eles, poderão aumentar significativamente as ligações aéreas entre as duas cidades. Apesar da maior duração dos tempos de vôos, tais localidades teriam maiores opções em termos de freqüências e conseqüentemente de horários de partidas.

Para avaliar a coordenação entre a programação de vôos de chegadas e de partidas das principais companhias aéreas européias em seus aeroportos hubs, o Grupo de Estudos de Transporte, da Universidade de Westminster, no Reino Unido, criou uma medida denominada de taxa de conectividade, que mede a concentração de vôos operada no hub.

A taxa de conectividade provê uma estimativa da extensão pela qual a programação de horários é configurada com o propósito de oferecer conexões em vez de ser apenas o resultado de ligações ao acaso entre os vôos. Inicialmente, calcula-se o número total de conexões oferecidas pela companhia aérea hub, em um intervalo de 90 min em determinado dia. Este valor então é comparado com o número que poderia resultar se os horários de chegadas e partidas fossem aleatórios ao longo de 15 horas do dia, de 07:00h às 22:00h na maioria dos 
aeroportos. Assim, a taxa de conectividade é o número resultante das conexões realizadas dividido pelo número das conexões possíveis naquele aeroporto pela companhia aérea $h u b$.

Com o valor igual a 1, a taxa de conectividade equivale a um padrão de movimento aleatório ou uniforme ao longo do dia, sem criar mais conexões do que seria esperado por casualidade. A taxa de 1,8 implica que $80 \%$ mais ligações, durante uma determinada hora da programação de horários, acima de um período de tempo de 90 minutos, estariam disponíveis do que seria esperado eventualmente. Em outras palavras, uma taxa de 2,0 indica que houve duas vezes mais conexões realizadas do que ocorreria em bases normais do tráfego de transferência.

\subsection{8}

\section{REDE OU MALHA AÉREA}

Rede ou malha aérea consiste no conjunto de linhas do tráfego regular operadas por uma empresa transportadora para atender às necessidades de movimentação de bens e pessoas, de acordo com a demanda do mercado. A rede de ligações constitui-se no principal produto oferecido pelas companhias aéreas aos seus usuários.

Programar vôos é um processo complexo, envolvendo a previsão de decolagens de aeronaves para cidades e em horários (oferta) que os consumidores desejam voar (demanda), com objetivo de convencer os passageiros a trocarem seus recursos econômicos (renda) pelos benefícios oferecidos (serviço) (Dempsey, 1997).

A escolha dos destinos para onde as aeronaves poderiam voar, e a que horas do dia, exige um pensamento em várias dimensões, guardando uma analogia onde as peças movem-se continuamente. As rotas devem analisar o padrão do tráfego de passageiros, tendências econômicas, programas de manutenção, necessidade de abastecimento de combustível, horários de vôos, intervalos de carregamento e descarregamento, regras de ruído aeronáutico, disponibilidade de slots, proibição de operações noturnas (curfew), custos de pessoal, preço de combustível e níveis de tarifas, entre uma dúzia de outros fatores, em cada mercado operado pela empresa.

A partir dessas variáveis, o programador elabora o planejamento dos vôos que serve de base para a companhia estabelecer a necessidade de recursos financeiros, quantificação de pessoal, estratégia de vendas e planos de contingência para condições meteorológicas adversas, falhas 
mecânicas, bem como outros obstáculos que podem aparecer nos serviços aéreos. A combinação desses fatores cresce aritmeticamente em função do número de aeronaves em operação e geometricamente em relação à quantidade de tipos de aviões que compõem uma frota (Dempsey, 1997).

O objetivo maior do planejamento de vôos é servir às cidades por intermédio de um sistema de rotas de modo a atender à demanda dos viajantes e obter um adequado retorno de lucro para a empresa aérea.

Do ponto de vista do consumidor o fator mais importante na escolha do serviço aéreo de uma empresa está ligado à programação de linhas compreendendo a disponibilidade e as frequências dos vôos, o horário de chegadas e partidas e as rotas operadas. Segmentos diferentes do mercado terão exigências diversas em relação à oferta dos serviços. As ligações de curta distância por motivo de negócio, em geral, requerem no mínimo uma decolagem pela manhã e um vôo no final do dia, em cada direção, durante os dias úteis da semana, de modo a permitir a realização de uma viagem a negócios completa no mesmo dia. Enquanto os vôos nos finais de semana são fundamentais para atender o desejo de passageiros que viajam por motivo de lazer. Então as frequências e horários de chegada e partida devem ser estabelecidos de acordo com o tipo de mercado.

Outra variável a ser considerada, na programação de linhas, liga-se à distância do percurso e ao nível de competição. Por exemplo, oferecer um vôo diário em um mercado onde as transportadoras concorrentes já possuam 10 vôos por dia, certamente não será obtido quase nenhum impacto. As linhas de longa distância, com muitas horas de vôo, são naturalmente realizadas durante a noite, quando os passageiros dormem. Assim, uma empresa aérea terá que combinar esses fatores de modo a oferecer um produto que supra as necessidades dos seus passageiros potenciais.

A programação da estrutura da malha de rotas é um processo complexo que envolve não somente às exigências de segmentos do mercado, mas também podem ser alteradas em função das áreas geográficas a serem atendidas e dos preços das tarifas praticados. A combinação desses variáveis em determinado mercado será de importância fundamental para corresponder com sucesso às expectativas dos consumidores. 
Ao contrário do mito popular, as transportadoras não cancelam vôos porque estão com os respectivos índices de aproveitamento muito baixos. A natureza dos serviços aéreos pressupõe uma programação pré-determinada ao longo de cada dia percorrendo o trajeto de cada rota da companhia. O cancelamento de um vôo em um aeroporto significa que aquela aeronave não chegará em algum lugar mais tarde no mesmo dia, sendo portanto necessário cancelar outro vôo.

A importância da malha aérea, juntamente com a tarifa, na composição do produto a ser oferecido por uma operadora é enfatizada pelo fato de que o consumidor pode estabelecer comparações objetivas e precisas entre as alternativas disponíveis no mercado, tanto em relação aos vôos, quanto na escolha da empresa aérea. Assim, é possível confrontar um horário de decolagem com outro, os tempos de duração da viagem, se os vôos são diretos ou com escalas, bem como os valores das tarifas.

No período anterior a desregulação, a elaboração da rede de linhas enfocava principalmente os níveis de demanda de passageiros, o motivo da viagem e a capacidade instalada dos aeroportos. A malha aérea era composta das chamadas linhas tronco, de alta densidade, servindo aos grandes centros econômicos do território, normalmente operadas por vôos diretos sem escalas. As demais ligações atendiam outras regiões secundárias, carreando tráfego para os pontos principais, que eram denominadas de linhas alimentadoras. $\mathrm{Na}$ configuração da rede havia predominância das linhas ponto a ponto, caracterizadas por uma programação de rotas de origem e destino através de diversas localidades com idêntico percurso de retorno (Dempsey, 1997).

\subsection{9}

\section{REDES LINEAR}

Nesse item são mostrados os diversos aspectos que envolvem a estrutura de malhas aéreas, reunindo os conceitos correspondentes encontrados na bibliografia pesquisada e observados nas operações de empresas aéreas. Basicamente, foi possível identificar dois tipos de redes: a linear e a hub and spoke.

A rede linear é caracterizada pelo transporte do tráfego de origem e destino, em rotas diretas sem escalas, bem como as denominadas de ponto-a-ponto, que se constituem de uma seqüência de ligações diretas (múltiplas escalas). Esses tipos de rede constituem-se num 
método tradicional de programação de linhas, na qual a aeronave, após chegar ao destino final, retorna pela mesma rota até o ponto inicial de origem.

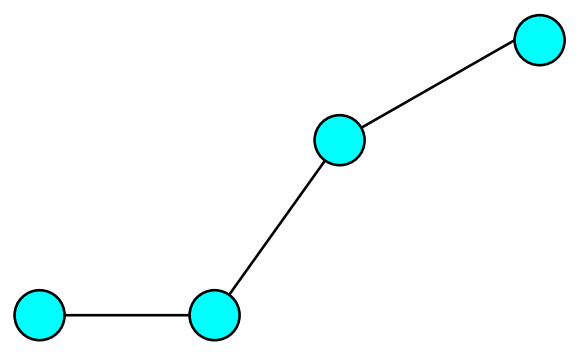

Figura 2.6 - Esquema de Rede Linear

As vantagens obtidas pelas companhias aéreas que se utilizam do conceito hub em suas malhas inúmeras em relação às congêneres que operam predominantemente no sistema ponto a ponto. A empresa aérea dispondo de hub ganha maior poder de barganha em relação à concorrência, pois nele dispõe de facilidades e serviços em um único terminal.

Segundo definição da FAA, conexão é o passageiro que desembarca e embarca, no mesmo aeroporto, em uma aeronave diferente daquela que ele embarcou no primeiro trecho da viagem. Entretanto, esta definição não é precisa, pois o passageiro pode desembarcar e embarcar para o seu destino final na mesma aeronave basta que o número do vôo seja diferente. A definição mais correta seria: o passageiro que desembarca e embarca, no mesmo aeroporto, cujo do destino seja diferente da sua origem e diferentes números de vôos, independendo se a aeronave é a mesma ou não, pois a mesma pode oferecer preços mais baixos e, ainda, suprir os assentos disponíveis para os usuários de programa de milhagem.

Se houver concorrência no hub, os preços para os passageiros locais serão reduzidos.

Caso contrário, o preço será aumentado, garantindo assim uma maior lucratividade. Esse poder de barganha da companhia aérea que irá desencorajar a entrada da concorrência no aeroporto operado pela companhia operadora do sistema hub and spoke. 
Além do alto poder de barganha diante da concorrência, o hub proporciona outras vantagens como: maior número de ligações diretas; facilidade de transferência de vôos; curto tempo de conexão para vôos de pequenas distâncias; maximizar as rotas para a economia local.

\subsection{1}

\section{DESVANTAGENS DO SISTEMA HUB}

Apesar de ser economicamente viável tanto para companhias aéreas quanto passageiros, o sistema hub and spoke apresenta algumas desvantagens para as ambas as partes. No lado da companhia aérea, as desvantagens ocorrem nos seguintes aspectos: Os atrasos em cadeia, congestionamentos da infra-estrutura aeroportuária, custo adicionais com handling e de combustível, grandes hubs, como exemplo, Chicago; Atlanta, Londres; Los Angeles, Frank e tráfego aéreo.

O movimento simultâneo de várias aeronaves gera uma sobrecarga na infra-estrutura do aeroporto, na movimentação de passageiros, carga, bagagem e no serviço às aeronaves. Qualquer atraso em uma das vagas ou ondas poderá acarretar a perda da conexão no sistema hub and spoke e/ou em outros aeroportos spoke.

Em relação aos passageiros, as desvantagens, ocorrem na duração da viagem e no desconforto que ela gera. Ao optar por prazo a mais demorada do que a viagem ponto a ponto porque haverá uma espera no aeroporto hub até uma hora atrasado

Além da demora em chegar ao seu destino final e o risco de perder a conexão, a viagem através do sistema hub and spoke gera o desconforto de ter assentos diferentes em conexão.

Basicamente sujeito a dois casos:

a) Perda de conexão

b) Extravio de bagagens.

No que tange a responsabilidade civil, o sistema hub and spoke está: 
A perda de conexão e/ou extravio de bagagem estão associados ao atraso no vôo com destino ao hub e o curto MCT.

Focus city é o aeroporto que não é considerado um hub, mas possui vários destinos diferentes dos que há no hub. Geralmente, nos aeroportos focus city há apenas um vôo diário ou até mesmo semanal para determinado destino. Exemplos de companhias aéreas que utilizam o sistema focus city: Dulles (IAD) Jet Blue e Hamburgo (HAM) Lufthansa.

$\mathrm{Na}$ matéria realizada pelo jornal on line The Financial Express, no dia 08/12/05, constatou o aumento adicional dos custos dos combustíveis nas contas das companhias aéreas pela demora, em média de 25 minutos, nas autorizações das decolagens ou aterrissagens.

Em relação às condições meteorológicas, o sistema sofrerá um efeito dominó durante todo o dia ou, mesmo após a normalização dos pousos e decolagens. A demora na normalização dos horários do operador do hub é proporcional ao somatório do número de vôos que foram alternados para outros destinos; cancelados; e atrasados pelo fechamento ou restrição de pousos e decolagens, ou seja, quanto mais vôos alternados; cancelados e atrasados, maior será a demora em normalizar todo o sistema. Neste caso, há excludente e a companhia aérea não poderá ser responsabilizada. 
Tabela 2.3 - Principais Hubs pelo Mundo

\begin{tabular}{|c|c|c|}
\hline \multicolumn{3}{|c|}{ ÁSIA } \\
\hline EMPRESA & CIDADE & PAÍS \\
\hline$A N A$ & \multirow{2}{*}{ Tóquio (NRT e HND), KANSAI (KIX), AND ITAMI } & \multirow[t]{2}{*}{ JAPÃO } \\
\hline JAL & & \\
\hline AIR CHINA & BEIJING & \multirow[t]{2}{*}{ CHINA } \\
\hline CATHAY PACIFIC & HONG KONG & \\
\hline ASIANA AIRLINES & INCHEON AND GIMPO & \multirow[t]{2}{*}{ CORÉIA DO SUL } \\
\hline KOREAN AIRLINES & INCHEON AND GIMPO & \\
\hline EVA AIR & TAIPEI & TAIWAN \\
\hline $\begin{array}{l}\text { SINGAPORE } \\
\text { AIRLINES }\end{array}$ & CHANGAI & CINGAPURA \\
\hline THAI & BANGKOK & TAILÁNDIA \\
\hline \multicolumn{3}{|c|}{ OCEANIA } \\
\hline AIR NEW ZEALAND & AUCKLAND,CHRISTCHURCH AND LOS ANGELES & \multirow[t]{2}{*}{ AUSTRÁLIA } \\
\hline QANTAS & Sidney, MELBOURNE,PERTH & \\
\hline
\end{tabular}

\begin{tabular}{|c|c|c|}
\hline \multicolumn{3}{|c|}{ AMÉRICA DO NORTE } \\
\hline EMPRESA & CIDADE & PAÍS \\
\hline$A I R C A N A D A$ & Toronto,Vancouver, Montreal & CANADÁ \\
\hline ALASKA AIRLINES & Seatle, Portland, Los Angeles, Anchorage & \multirow{8}{*}{ 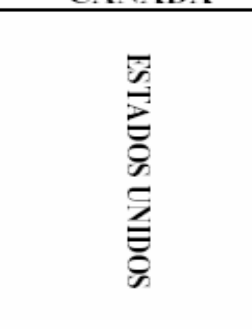 } \\
\hline $\begin{array}{l}\text { AMERICAN } \\
\text { AIRLINES }\end{array}$ & Dallas, Chicago, Miami, ST. Louis, San Juan (Porto Rico) & \\
\hline CONTINENTAL & Newark, Houston, Cleveland, Guam & \\
\hline DELTA & Atlanta, Cincinnati, Salt Lake City, New York (JFK). & \\
\hline NORTHWEST & Minneapolis, Detroit, Memphis, Tokyo, Amsterdam & \\
\hline SOUTHWEST & Cmn, Las Vegas, Phoenix & \\
\hline$\overline{U N I T E D}$ & $\begin{array}{l}\text { Chicago, Denver, Washington (IAD), San Francisco, Los } \\
\text { Angeles, Tóquio }\end{array}$ & \\
\hline US AIRWAYS & Charlotte, Philadelphia, Phoenix. & \\
\hline \multicolumn{3}{|c|}{ AMÉRICA LATINA } \\
\hline EMPRESA & CIDADE & PAÍS \\
\hline$A E R O M E X T C O$ & Cidade do México HERMOSILLO APODACA & \multirow{2}{*}{ MÉXICO } \\
\hline MEXICANA & GUADALAJARA CIDADE DO MÉXICO & \\
\hline$L A N$ & SANTIAGO,LIMA & CHILE \\
\hline VARIG & RIO DE JANEIRO (GIG), SÃO PAULO(GRU) & \multirow{3}{*}{ BRASIL } \\
\hline TAM & SÃO PAULO (GRU E CGH) & \\
\hline$G O L$ & SÃO PAULO $(\mathrm{CGH})$ & \\
\hline \multicolumn{3}{|c|}{ EUROPA } \\
\hline EMPRESA & CIDADE & PAÍS \\
\hline AER LINGUS & DUBLIN & IRLANDA \\
\hline AIR FRANCE-KLM & Paris e Amsterdam & $\begin{array}{l}\text { FRANCA / } \\
\text { HOLANDA }\end{array}$ \\
\hline BRITISH AIRWAYS & Londres (LHR, LGW), Manchester & \multirow{2}{*}{ INGLATERRA } \\
\hline VIRGIN ATLANTIC & Londres (LHR, LGW), & \\
\hline IBERIA & MADRID & ESPANHA \\
\hline LUFTHANSA & FRANKFURT, MUNIQUE & ALEMANHA \\
\hline SAS & COPENHAGEN STOCKHOLM- OSLO & $\begin{array}{l}\text { DINAMARCA, } \\
\text { SUECIA E } \\
\text { NORUEGA }\end{array}$ \\
\hline AEROFLOT & MOSCOU & RÚSSIA \\
\hline$C S A$ & PRAGA & REP.CHECA \\
\hline$\overline{L O T}$ & VARSÓVIA & POLÔNIA \\
\hline$M A L E V$ & BUDAPESTE & HUNGRIA \\
\hline \multicolumn{3}{|c|}{ AFRICA AND MIDDLE EAST } \\
\hline EMPRESA & CIDADE & PAÍS \\
\hline EGYPTAIR & CAIRO & EGITO \\
\hline$S A A$ & JOHANNESBURG CAPE TOWN & ÁFRICA DO SUL \\
\hline EMIRATES & DUBAI & EMIR.ÁRABES \\
\hline \multicolumn{3}{|c|}{ AFRICA AND MIDDLE EAST } \\
\hline QATAR AIRWAYS & DOHA & CATAR \\
\hline$E L A L$ & TEL AVIV & ISRAEL \\
\hline
\end{tabular}




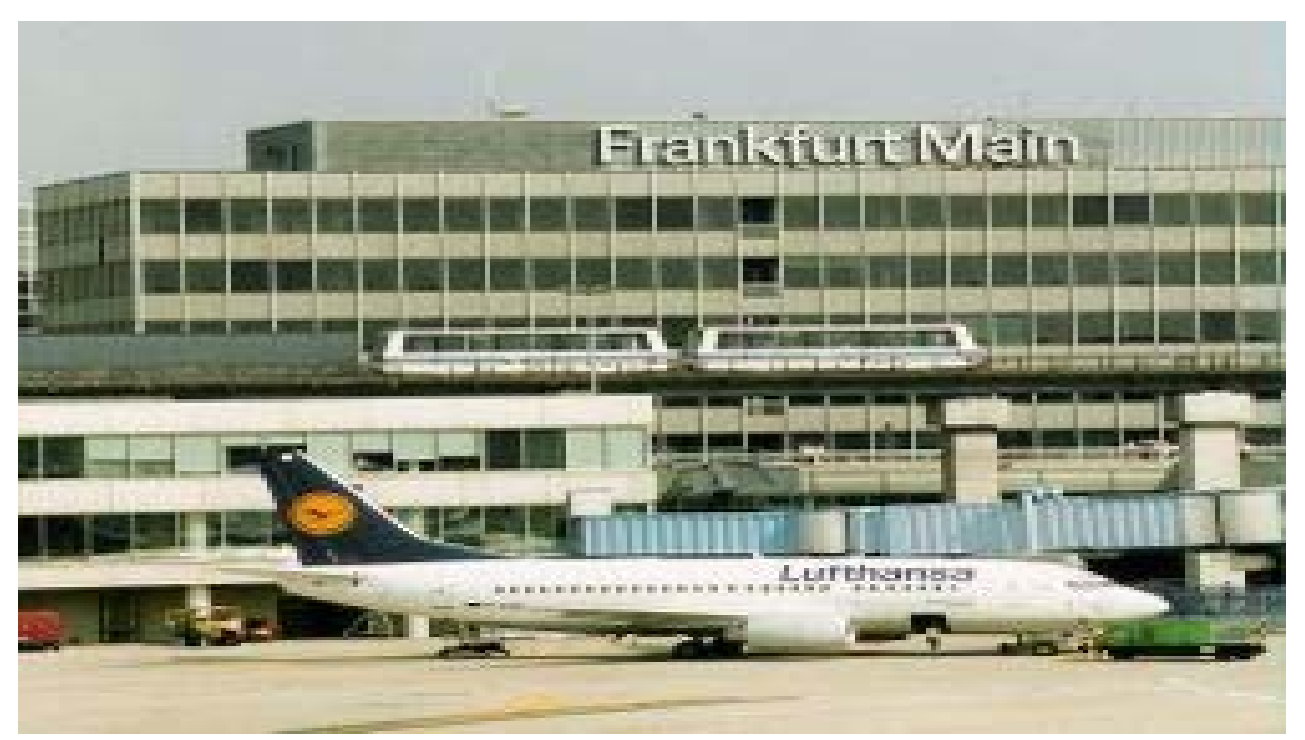

Figura 2.7 - Aeroporto Internacional de Frankfurt, Alemanha

Aeroportos que atuam como hub geralmente são dotados de centro aeroportuário de grande porte e são bem equipados para o atendimento de aeronaves de grande porte, bem como para o grande tráfego de passageiros pelo saguão do aeroporto. Existem áreas destinadas ao checkin, terminais separados para embarque (onde o passageiro espera o seu vôo) e desembarque (esteiras de restituição de bagagem, por exemplo), comerciais (lojas, bancos, casas de câmbio, etc), e estacionamento de carros. Possuem máquinas de raios-X, para a detecção de materiais perigosos na bagagem de passageiros.

Aeroportos internacionais (destinados ao atendimento de vôos procedentes ou com destino a outros países) possuem também uma alfândega, onde passageiros que saem ou entram do país são controlados pelos serviços aduaneiros. Grandes hubs aéreos oferecem ao passageiro uma grande variedade de serviços, como salas VIP, centro comercial de grande porte, playgrounds, lugar de culto religioso, museu, restaurantes, lanchonetes, etc.

Grandes terminais aeroportuários objetivando operar como hub, precisam ser planejados e construídos de forma a poder cobrir o maior número de passageiros possível, na mesma medida em que os espaços destinados ao estacionamento das aeronaves são maximizados. 


\subsubsection{Logística de Transporte de Superfície nos Pátios do Hub}

Quando os terminais de passageiros estão afastados uns dos outros e/ou distantes do terminal principal, linhas de ônibus, trens especiais e esteiras rolantes conectam um terminal ao outro, de modo a facilitar o movimento de passageiros e funcionários entre todos os terminais, principalmente aqueles que terão embarque de passageiros em conexão e irão operar como hub. Na figura 2.9 também apresenta a circulação de vários veículos que deverão estar totalmente controlados.

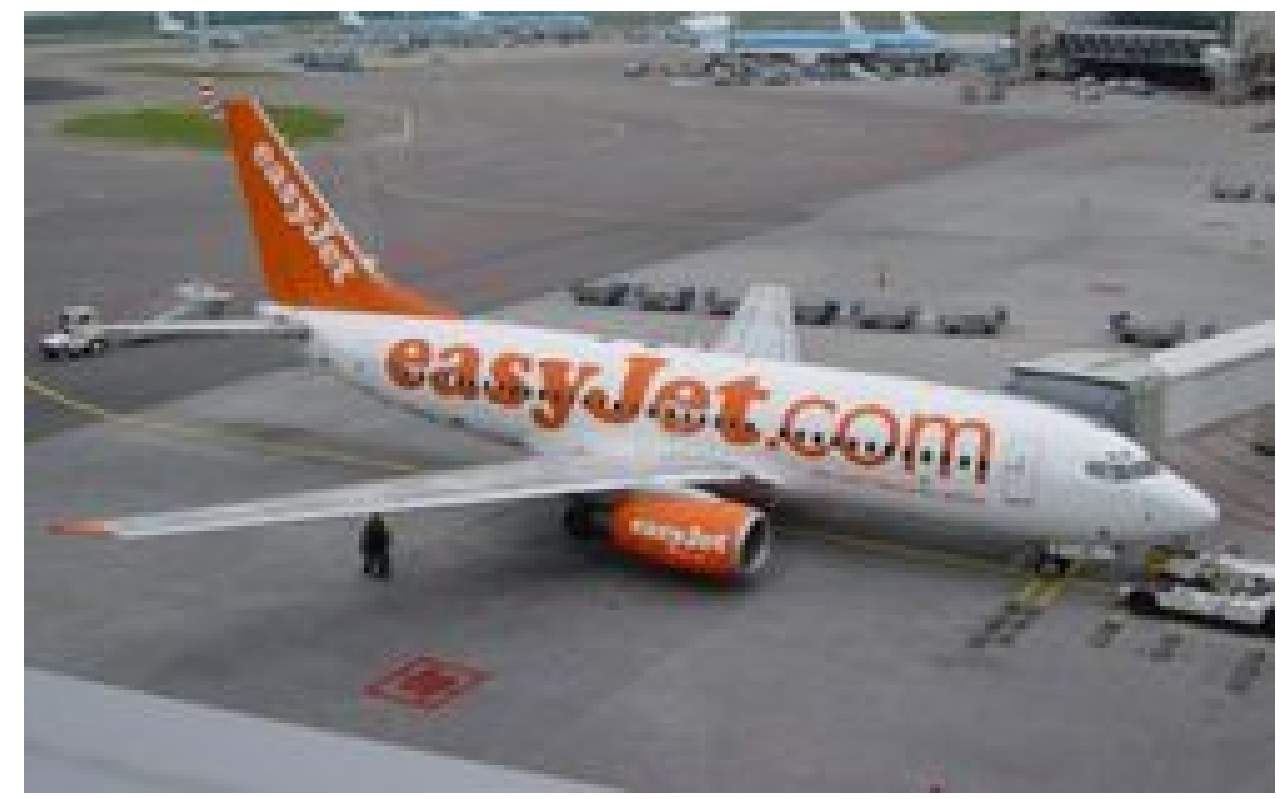

Figura 2.8 - Avião da EasyJet no Aeroporto Internacional de Amsterdã, Holanda

Observe os vários veículos presentes em torno da aeronave. Os aviões não são os únicos meios de transporte presente numa área aeroportuária: uma variedade de veículos diferentes atua dentro do aeroporto, com uma gama variada de serviços, como o transporte de passageiros, transporte de carga, bagagem, comida e limpeza das aeronaves, guia de ré em aeronaves e escadas móveis.

Veículos aeroportuários deslocam-se no aeroporto através de faixas a eles destinadas. Outras faixas existem, dedicadas à orientação das aeronaves, no pátio de estacionamento e nas taxiways. 


\subsubsection{Carga e Correio Aéreo}

Os aeroportos possuem geralmente uma área designada especialmente para o manejamento de carga, com hangares destinados ao estoque da carga a ser transportada e equipamentos necessários para o seu manejamento, bem como pessoal especializado. Em especial as aeronaves geralmente transportam grande quantidade de cargas em seus porões, sendo assim o aeroporto hub apresenta mais esta característica que poderá ser explorada pelas empresas aéreas e seus clientes.

\section{POLUIÇÃO DOS AEROPORTOS}

- Poluição atmosférica, criada pelos motores de veículos e aeronaves. O maior problema neste caso é mesmo a poluição atmosférica gerada pelo tráfego de veículos que vêm e vão do aeroporto.

- Poluição sonora, criada pelo barulho do tráfego de veículos e pelas aeronaves, principalmente em operações de pouso e decolagem. Isto é problemático principalmente em grandes aeroportos internacionais, onde as horas da noite são as mais movimentadas quanto ao número de operações de pouso e decolagem.

Tais problemas podem causar danos à saúde dos habitantes que moram na sua proximidade, como problemas de sono ou respiratórios. A construção de um novo aeroporto não é, geralmente, bem recebida pelos habitantes que moram perto da área escolhida (até tanto pela possibilidade da necessidade de deslocamento de vários desses habitantes para outros lugares da cidade).

\subsection{6}

\section{AEROPORTOS HUB E SUAS ESTATÍSTICAS}

- O maior aeroporto em movimento de passageiros é o Aeroporto Internacional Hartsfield, em Atlanta, nos Estados Unidos da América com movimento de 88,4 milhões de passageiros por ano, seguido por perto pelo Aeroporto Internacional O'Hare, em Chicago, Illinois, também nos Estados Unidos, que movimentou 77 milhões de passageiros em 2004. 
- O maior aeroporto de tráfego internacional do mundo é o Aeroporto Internacional Heathrow, em Londres, Inglaterra, com uma média de 460 mil pousos e decolagens por ano. $80 \%$ do seu movimento anual de 67 milhões de passageiros é através de vôos internacionais.

- O maior aeroporto de tráfego local do mundo é o Aeroporto Internacional de Los Angeles. Cerca de $60 \%$ do seu movimento anual de 60 milhões de passageiros possui como destino ou ponto de partida a região metropolitana de Los Angeles.

- O aeroporto de carga aérea mais movimentado do mundo é o Aeroporto Internacional de Memphis, Tennessee, nos Estados Unidos. Ali, está localizado o centro operacional da FedEx.

- Aeroporto de maior altitude e pista mais longa: Bangda, no Tibete, situado a 4334 metros de altitude, cuja pista principal possui 5.500 metros.

- A maior pista de pouso do mundo está localizada na base aérea de Edwards, California, coordenadas $34^{\circ} 49^{\prime} 27.92^{\prime \prime} \mathrm{N} 117^{\circ} 51^{\prime} 37.11^{\prime \prime W}$. É de terra e tem aproximadamente 12.000 . 
No Brasil, o processo de flexibilização da regulamentação começa no início dos anos 1990. A política de competição controlada, que se caracteriza por uma forte intervenção estatal no controle de rotas e tarifas, vigente desde os anos 1960 é gradativamente abandonada. Ao longo dos anos 1990 assistimos à abertura do mercado e ao abandono do controle tarifário. Como conseqüência observamos um intenso movimento de entrada e saída de companhias aéreas resultando na concentração do setor. No período estudado ocorreu uma grande elevação das atividades do setor concomitante a redução do emprego, dos salários e do tempo de serviço, indicando uma maior instabilidade no mercado de trabalho da aviação comercial brasileira. Observamos ainda uma significativa redução de custos com pessoal por parte das companhias aéreas.

A desregulação do sistema de aviação civil brasileiro, proporcionou condições de flexibilização, que hoje em dia encontram-se semelhantes à americana. O forte aumento do tráfego criou condições para o surgimento do sistema hub na sua forma plena em alguns aeroportos principais.

É o aeroporto que serve a capital do Brasil, Brasília. Seu nome é em homenagem ao expresidente do Brasil, Juscelino Kubitschek. É o terceiro mais movimentado do país, após Congonhas e Cumbica, somente após o desenvolvimento do hub fomentou o tráfego. $\mathrm{O}$ aeroporto possui duas pistas, com o movimento de passageiros em 2007 de 11.119.872.

\subsubsection{1 - Empresas Aéreas que Operam no Aeroporto e Destinos a Partir de Brasília}

$\sqrt{ } \quad$ TAP Portugal (Lisboa e Porto);

$\sqrt{ }$ GOL Transportes Aéreos (Aracajú, Belém, Belo Horizonte, Boa Vista, Campinas, Cuiabá, Curitiba, Fortaleza, Foz do Iguaçu, Goiânia, Imperatriz, 
Macapá, Manaus, Marabá, Natal, Palmas, Porto Alegre, Porto Velho, Recife, Rio Branco, Rio de Janeiro, Rosário (ARG), Salvador, São Luís, São Paulo, Teresina, Vitória);

$\sqrt{ }$ TAM (Aracajú, Belém, Belo Horizonte, Boa Vista, Buenos Aires, Campinas, Campo Grande, Corumbá, Criciúma, Cuiabá, Curitiba, Florianópolis, Fortaleza, Foz do Iguaçu, Goiânia, Imperatriz, Ji-Paraná, João Pessoa, Macapá, Maceió, Manaus, Marabá, Natal, Palmas, Porto Alegre, Porto Velho, Recife, Rio Branco, Rio de Janeiro, Salvador, São José do Rio Preto, São Luís, São Paulo, Teresina, Vitória);

$\sqrt{ }$ Varig (Buenos Aires, Manaus, Porto Alegre, Recife, Rio de Janeiro - Galeão e São Paulo - Congonhas) OceanAir (Belo Horizonte, Campo Grande, Chapecó, Goiânia, Florianópolis, Ilhéus, Maceió, Petrolina, Porto Alegre, Recife, Rio de Janeiro, Salvador, São Luiz, São Paulo (Congonhas), São Paulo (Guarulhos), Teresina, Belo Horizonte (Confins), Belo Horizonte (Pampulha), Montes Claros, Ipatinga);

$\sqrt{ }$ Total Linhas Aéreas (Altamira, Araguaína, Belém, Belo Horizonte (Pampulha), Carajás, Manaus, Parintins, Santarém, Trombetas, Tucuruí, Uberaba, Uberlândia);

$\sqrt{ } \quad$ Abaeté (Barreiras, Salvador, Guanambi, Bom Jesus da Lapa);

$\sqrt{ } \operatorname{SETE}$ (Confresa, Goiânia, Gurupi, Minaçu, São Félix do Araguaia);

$\sqrt{ }$ TRIP (Campo Grande, Cascavel, Curitiba, Goiânia, Londrina, Maringá, Belo Horizonte (Pampulha), Governador Valadares).

\subsection{2}

\section{O Aeroporto Internacional de São Paulo (Guarulhos)}

É o principal e o segundo mais movimentado aeroporto do Brasil, localizado na cidade de Guarulhos, no bairro de Cumbica, distante 25 quilômetros do centro de São Paulo, principal metrópole que o aeroporto serve. Movimento de passageiros em 2007, 18.795.596.

Sendo um hub na América do Sul, Guarulhos é o aeroporto com maior movimento internacional do Brasil e o segundo em tráfego total de passageiros, somente ficando atrás do Aeroporto de Congonhas. No transporte de carga, é o maior da América Latina e ocupa a $37^{\mathrm{a}}$ posição entre os mais movimentados do mundo. 
Com uma área de $14 \mathrm{~km}^{2}$, dos quais $5 \mathrm{~km}^{2}$ é área urbanizada, o complexo aeroportuário conta com um sistema de acesso viário próprio. A Rodovia Helio Smidt se estende por parte do perímetro do aeroporto, tendo ligação com as rodovias Presidente Dutra e Ayrton Senna.

Toda estrutura para passageiros é dividida em dois terminais (TPS1 e TPS2) com 260 balcões de check-in, onde as atividades operacionais funcionam 24 horas por dia. Operam 37 companhias aéreas nacionais e internacionais, voando para 23 países em mais de 100 cidades do Brasil e do mundo.

A Emirates é a mais nova empresa a iniciar atividades no aeroporto, em 1 de outubro de 2007, com freqüências para Dubai. A Qatar Airways do Catar adiou a estréia de sua rota para São Paulo do primeiro semestre de 2007, para o primeiro semestre de 2008.

No Plano Diretor do aeroporto está prevista a construção de mais dois terminais de passageiros (TPS 3, TPS 4) e uma terceira pista adicional às duas já existes, atingindo a capacidade máxima de expansão para processamento de vôos, passageiros e carga.

Em 28 de novembro de 2001 uma lei federal alterou a denominação do aeroporto em homenagem ao ex-governador do estado de São Paulo, André Franco Montoro, falecido em 1999, o qual, como governador prejudicou muito o aeroporto. No entanto, o nome oficial não é habitualmente usado pela população, que resiste e prefere se referir a ele como Aeroporto de Guarulhos ou simplesmente Cumbica.

\subsubsection{Empresas Aéreas que Operam no Aeroporto e Destinos a Partir de Guarulhos}

- Air Minas (Bauru-Arealva, Belo Horizonte-Pampulha, Divinópolis, Varginha)

- Air China (Pequim, Madri)

- Air France (Paris-Charles de Gaulle)

- Aerolíneas Argentinas (Buenos Aires-Ezeiza, Miami)

- Austral Líneas Aéreas (Buenos Aires-Aeroparque)

- Aeroméxico (Cidade do México)

- Aelitalia (Milão-Malpensa) 
- Avianca (Bogotá)

- Oceanair (Aracaju, Brasília, Campina Grande, Caruaru, Cascavel, Cidade do México, Curitiba, Florianópolis, Fortaleza, Ilhéus, Juazeiro do Norte, Luanda, Maceió, Montes Claros, Natal, Paulo Afonso, Petrolina, Porto Alegre, Recife, Rio de Janeiro-Galeão, Salvador, Vitoria da Conquista)

- British Airways (Buenos Aires-Ezeiza, Londres-Heathrow, Rio de Janeiro-Galeão)

- Delta Air Lines (Atlanta, Nova Iorque-JFK)

- Ibéria (Madri)

- Japan Airlines (Nova Iorque-JFK, Tóquio-Narita)

- $\quad K L M($ Amsterdã)

- United Airlines (Chicago-O'Hare, Rio de Janeiro-Galeão, Washington-Dulles)

- GOL (Aracaju, Assunção, Belém, Belo Horizonte-Confins, Belém, Boa Vista, Brasília, Buenos Aires-Ezeiza, Campina Grande, Campo Grande, Chapecó, Cuiabá, Curitiba, Córdoba, Florianópolis, Fortaleza, Foz do Iguaçu, Goiânia, Ilhéus, Imperatriz, João Pessoa, Juazeiro do Norte, Lima, Londrina, Macapá, Maceió, Manaus, Maringá, Montevidéo, Natal, Palmas, Petrolina, Porto Alegre, Porto Seguro, Porto Velho, Rio de Janeiro-Galeão, Recife, Rio Branco, Rosário, Salvador, Santa Cruz de la Sierra, Santarém, Santiago, São Luís, Teresina, Vitória)

- $\quad$ TAM (Aracaju, Belém, Belo Horizonte-Confins, Boa Vista, Brasília, Buenos AiresEzeiza, Campinas, Caracas, Campo Grande, Caxias do Sul, Comandatuba, Corumbá, Cuiabá, Curitiba, Florianópolis, Fortaleza, Foz do Iguaçu, Frankfurt, Goiânia, Imperatriz, João Pessoa, Joinville, Londres-Heathrow, Londrina, Macapá, Madri [Inicia em 21 de dezembro de 2007], Maceió, Manaus, Marabá, Maringá, Miami, Milão-Malpensa, Montevidéu, Natal, Nova Iorque-JFK, Palmas, Paris-Charles de Gaulle, Porto Alegre, Porto Seguro, Porto Velho, Recife, Rio de Janeiro-Galeão, Salvador, Assunção, Buenos Aires-Ezeiza, Ciudad del Este, Cochabamba, Curitiba, Montevidéu, Santa Cruz de la Sierra, Santiago, São Luiz Teresina Vitória )

- America Air (Alfenas, Belo Horizonte Pampulha, Juiz de Fora, Lins, Ourinhos, São José dos Campos)

- Pluna (Buenos Aires Aeroparque, Madri, Montevidéu, Punta del Este)

- Varig (Bogotá, Buenos Aires, Caracas, Cidade do México, Fernando de Noronha, Fortaleza, Frankfurt-Main, Londres-Heathrow, Madri , Manaus, Montevidéu, Paris- 
Charles de Gaulle, Porto Alegre, Recife, Rio de Janeiro-Galeão, Roma, Salvador, Santiago do Chile)

- Emirates (Dubai)

- Qatar Airways (Doha) [Inicia no segundo semestre de 2008]

- Air Canada (Toronto-Pearson)

- American Airlines (Dallas-Fort Worth, Miami, Nova Iorque-JFK, Rio de JaneiroGaleão)

- Copa Airlines (Cidade do Panamá)

- Continental Airlines (Houston-Intercontinental, Newark, Rio de Janeiro-Galeão)

- LAN Airlines (Santiago)

- LAN Argentina (Buenos Aires-Ezeiza)

- LAN Express (Santiago, Rio de Janeiro-Galeão)

- LAN Perú (Lima)

- AeroSur (La Paz, Santa Cruz de la Sierra)

- South African Airways (Joanesburgo)

- Swiss International Air Lines (Santiago, Zurique)

- TAP Portugal (Lisboa, Porto)

- TACA Perú (Lima, Quito)

Uma interligação por trilhos do aeroporto ao centro de São Paulo está em projeto através de uma Parceria Público-Privada proposta pela CPTM. Após a análise dos estudos e a definição das diretrizes dessa PPP, a CPTM realizará as Audiências Públicas e preparará o edital de licitação, com previsão de publicação em 2007. A assinatura do contrato está prevista para ocorrer em 2008 e o início da operação deverá ocorrer em 2010.

Além dos táxis comuns, a Guarucoop, uma cooperativa de taxistas, tem concessão da Infraero para operar com exclusividade as faixas para táxi do aeroporto. Os serviços oferecidos são tabelados, motoristas e recepcionistas bilíngües e a frota conta com mais de 650 veículos, todos com quatro portas e ar-condicionado. 
É o maior aeroporto da cidade do Rio de Janeiro e está localizado na Ilha do Governador, zona norte do município, a aproximadamente $20 \mathrm{~km}$ do Centro. Teve movimento de passageiros em 2007 e 10.352.211.

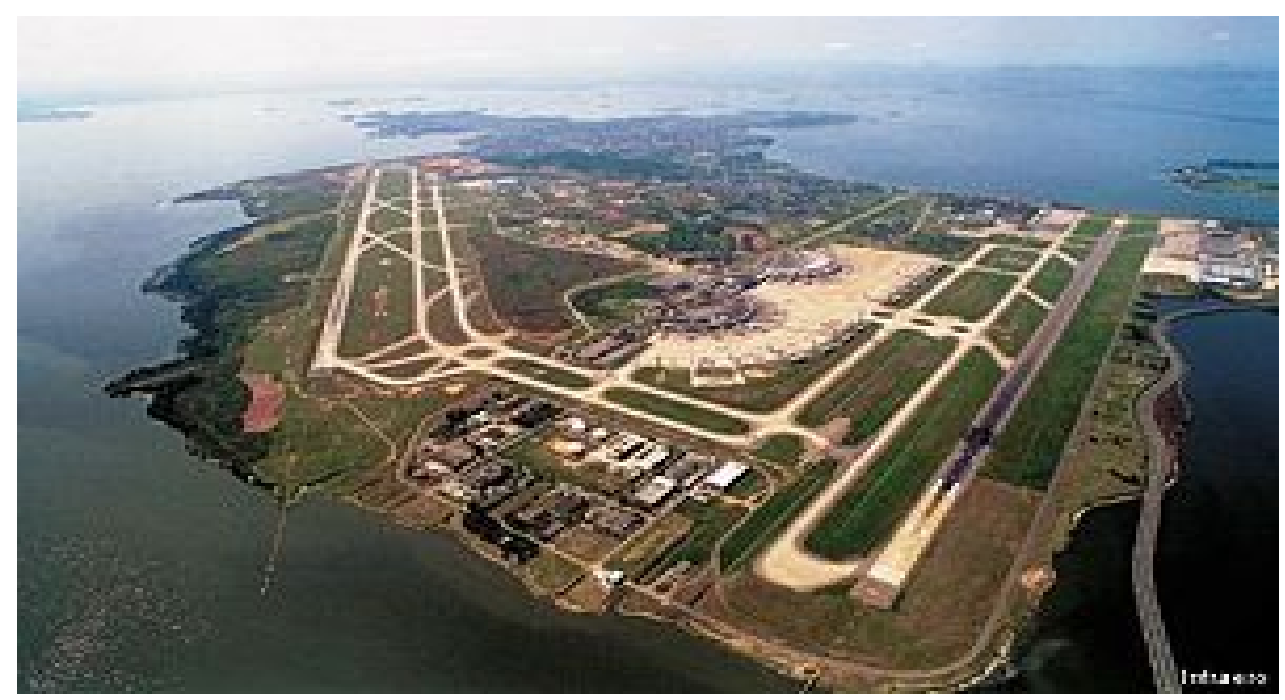

Figura 3.1 - Aeroporto Internacional do Rio de Janeiro

O Plano Diretor do aeroporto prevê a construção de mais dois terminais de passageiros (TPS3 e TPS4) além de uma nova pista, paralela à atual pista 10/28, porém em menor comprimento.

No dia 5 de janeiro de 1999, uma lei federal alterou a denominação do aeroporto, em homenagem ao músico e compositor Antonio Carlos Jobim, falecido em 1994.

\subsubsection{Empresas Aéreas que Operam no Aeroporto e Destinos a Partir do Galeão}

- Aerolíneas Argentinas (Buenos Aires-Ezeiza)

- Air Europa (Madri-Barajas)

- Air France (Paris-Charles de Gaulle)

- Avianca (Bogotá, São Paulo-Guarulhos)

- British Airways (Londres-Heathrow, São Paulo-Guarulhos)

- Continental Airlines (Houston-Intercontinental, São Paulo-Guarulhos)

- GOL (Aracaju, Belo Horizonte-Confins, Belém, Brasília, Buenos Aires-Ezeiza, Campinas, Curitiba, Florianópolis, Fortaleza, Goiânia, Ilhéus, João Pessoa, Manaus,Natal, Porto Iberia (Madri-Barajas) 
- LAN Chile (Santiago, São Paulo-Guarulhos)

- OceanAir (Alta Floresta, Aracaju, Araçatuba, Araguaína, Bauru, Belém, Belo Horizonte-Confins, Brasília, Campinas, Campo Grande, Cascavel, Chapeco, Cuiabá, Curitiba, Fortaleza, Foz do Iguaçu, Goiânia, Ji-Paraná, João Pessoa, Juazeiro do Norte, Maceió, México, Montes Claros, Natal, Palmas, Petrolina, Porto Alegre, Porto Velho, Presidente Prudente, Recife, Salvador, São Luis, São Paulo-Congonhas, São PauloGuarulhos, Teresina, Uberaba, Vitória da Conquista)

- $\quad$ TAAG (Luanda)

- Webjet (Belo Horizonte-Confins, Brasília, Curitiba, Fortaleza, Ilhéus, Natal, Porto Alegre, Porto Seguro, Salvador)

- Pluna (Madri, Montevidéu, Porto Alegre)

- TAM (Belo Horizonte-Confins, Belém, Brasília, Buenos Aires-Ezeiza, Campinas, Curitiba, Florianópolis, Fortaleza, Foz do Iguaçu, Ilhéus, João Pessoa,Manaus, Natal, Paris, Porto Alegre, Recife, Salvador, Lençóis, São Paulo-Congonhas, São PauloGuarulhos, Vitória)

- TAM Mercosur (Assunção, Buenos Aires-Ezeiza)

- TAP Portugal (Lisboa, Porto)

- United Airlines (São Paulo-Guarulhos, Washington-Dulles)

- Varig (Brasília, Buenos Aires-Ezeiza, Cidade do México, Curitiba, Fernando de Noronha, Frankfurt, Manaus, Paris, Porto Alegre, Recife, Roma, São PauloGuarulhos, Vitória) 


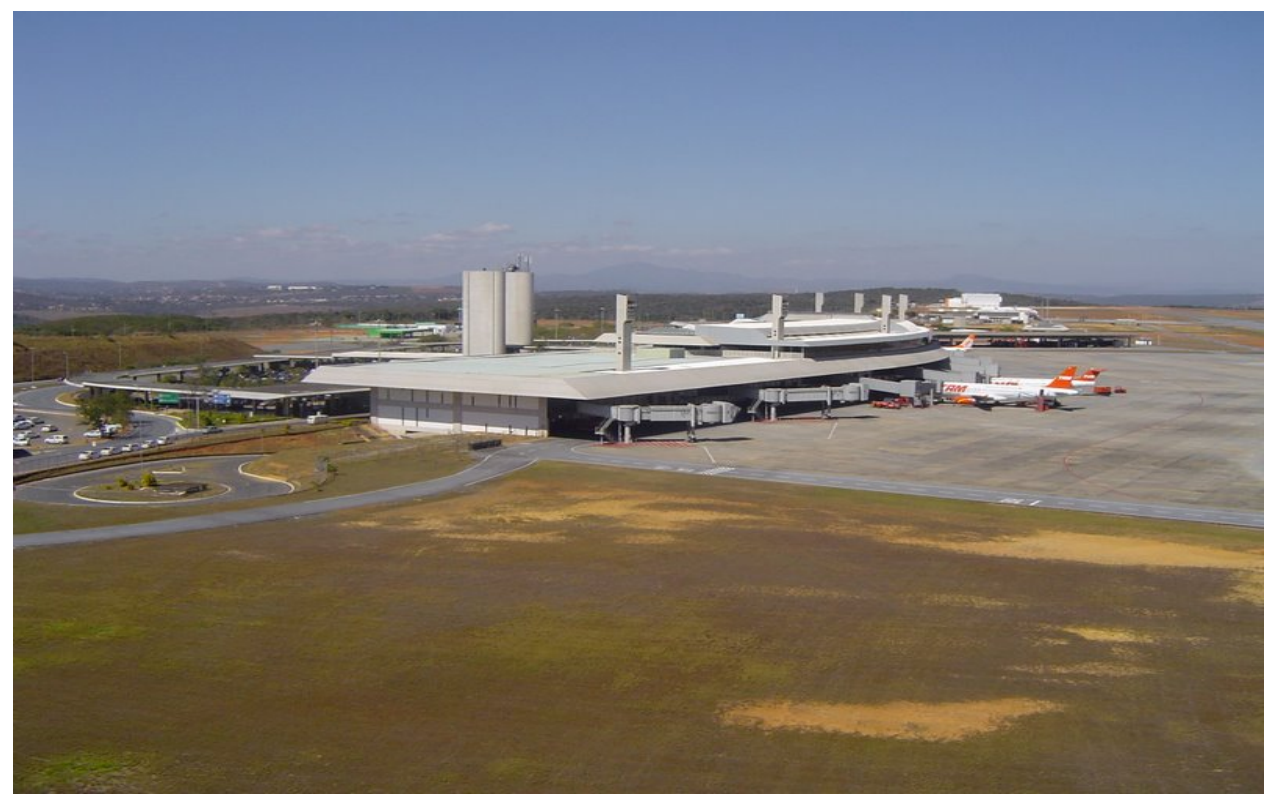

Figura 3.2 - Aeroporto Internacional Tancredo Neves

Encontra-se na Região Metropolitana de Belo Horizonte, no município de Confins. Um dos mais modernos do Brasil, o aeroporto vinha sofrendo grande ociosidade, devido principalmente à distância até o centro de Belo Horizonte, que é de cerca de $42 \mathrm{~km}$, sendo o mais distante aeroporto de sua região central no Brasil. Porém, a Infraero transferiu mais de 120 vôos do Aeroporto da Pampulha para o internacional Tancredo Neves no decorrer de 2005. Movimento de passageiros em 2007, 4.340.129

O trajeto do centro de Belo Horizonte até Confins da obra erá efetuado em até 90 minutos dependendo do horário. Atualmente, este percurso é realizado em aproximadamente 30 minutos.

Amplo, moderno, arejado (como deve ser um aeroporto de um país tropical) e funcional, o Aeroporto Internacional Tancredo Neves é o principal portal de entrada para o Estado de Minas Gerais e foi projetado para 5 milhões de passageiros por ano. No projeto original, quadro módulo de terminais ( 3 além do atual) formaria duas meias-luas completas, com duas pistas perpendiculares que possibilita pouso e decolagem simultâneo, característica fundamental para operações de sistema hub and spoke. Tal configuração aumentaria a capacidade do aeroporto para 20 milhões de passageiros por ano. 
O AITN, apesar de ter mais de 20 anos, sem qualquer reforma ou modificação profunda, ainda é um dos mais modernos do país, e por sua localização estratégica - um imenso platô sem habitações ao redor é um dos mais seguros do mundo.

Apesar da sua localização mais afastada do centro urbano, existem linhas de ônibus executivos, ônibus interurbanos e metropolitano que passam pelo terminal. Com a liberação da Linha Verde, a viagem do Centro ao Aeroporto terá uma média de 30 minutos.

Abaixo o projeto original, o volume atual da construção corresponde a apenas $25 \%$ do projeto, mas ainda não há previsão de sua expansão (somente do estacionamento):

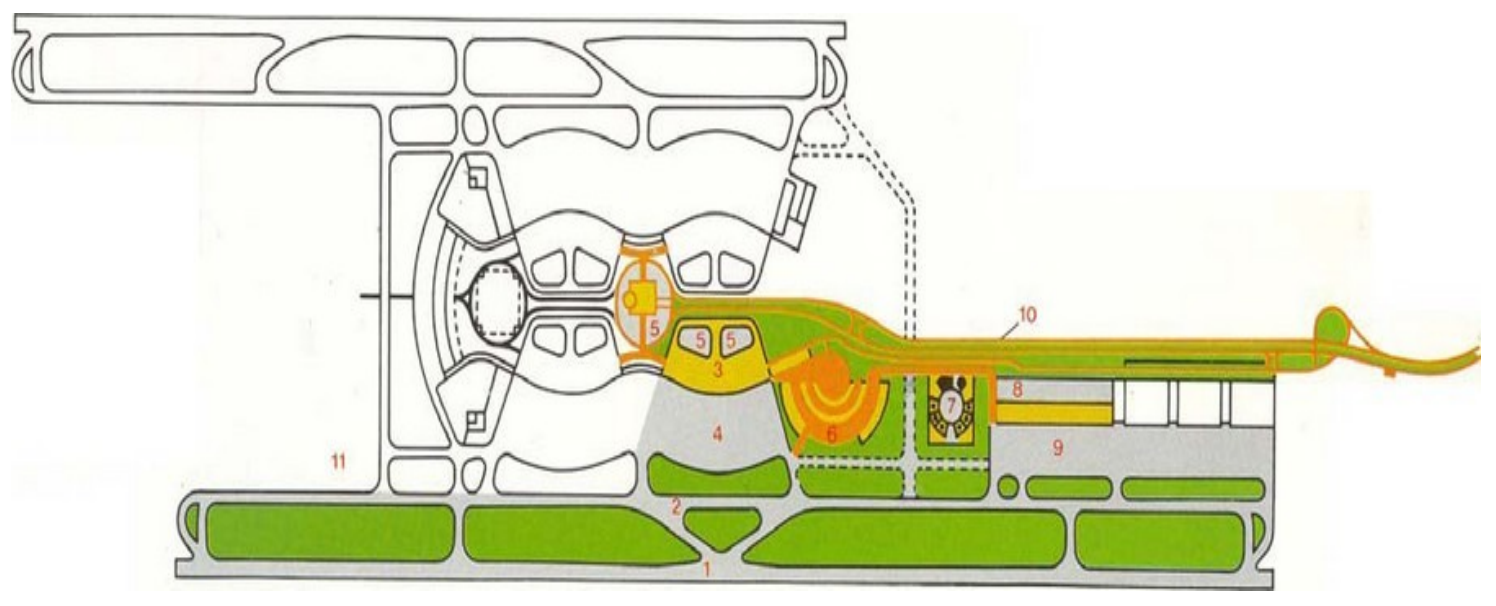

Figura 3.3 - Planta Baixa do Aeroporto Internacional Tancredo Neves

Portanto, já existem planos de expansão do aeroporto. Mesmo estando entre os três principais pólos aéreos do Brasil: São Paulo, Rio de Janeiro e Brasília.

\subsubsection{Empresas Aéreas que Operam no Aeroporto e Destinos a Partir de Confins}

- COPA Airlineas (Panamá). Previsão de início para setembro de 2008.

- GOL (São Paulo, Aracaju, Belém, Boa Vista, Brasília, Campo Grande, Cuiabá, Curitiba, Florianópolis, Fortaleza, Goiânia, João Pessoa, Macapá, Maceió, Manaus, Natal, Palmas, Porto Alegre, Porto Velho, Rio de Janeiro (GIG), Rio de Janeiro (SDU), Recife, Rio Branco, Salvador, São Luís, Teresina, Vitória, Campina Grande, Ilhéus, Joinville, Juazeiro do Norte, Londrina, Porto Seguro, Uberlândia) 
- OceanAir (São Paulo, Brasília, Campo Grande, Cuiabá, Curitiba, Florianópolis, Fortaleza, Goiânia, João Pessoa, Palmas, Porto Alegre, Porto Velho, Recife, Salvador, São Luís, Teresina, Ilhéus, Ipatinga, Montes Claros)

- TAM (São Paulo, Aracaju, Belém, Boa Vista, Brasília, Campo Grande, Cuiabá, Curitiba, Florianópolis, Fortaleza, Goiânia, João Pessoa, Macapá, Maceió, Manaus, Natal, Palmas, Porto Alegre, Porto Velho, Rio de Janeiro (GIG), Rio de Janeiro (SDU), Recife, Rio Branco, Salvador, São Luís, Teresina, Vitória, Campinas, Campina Grande, Ilhéus, Imperatriz, Joinville, Porto Seguro, Uberlândia)

- $\quad$ TAP (Lisboa - Portugal)

- TOTAL, ABSA e LAN (Cargo)

- VARIG (Brasília, Porto Alegre, Rio de Janeiro (GIG), Rio de Janeiro (SDU), São Paulo).

- WEBJET (Salvador, Maceió, Recife, Natal, Ilhéus, Rio de Janeiro (GIG), Porto Seguro).

\subsubsection{O Aeroporto de São Paulo (Congonhas)}

O Aeroporto e Congonhas/São Paulo é o segundo mais movimentado aeroporto do Brasil, teve um movimento de passageiros em 2007 de 15.244.401, está localizado na cidade de cidade de São Paulo, no distrito do Jabaquara, distante $8 \mathrm{~km}$ do marco zero da capital paulista. Com uma área pouco maior $1,5 \mathrm{~km}^{2}$, serve de acesso ao aeroporto a avenida Washington Luís, que tem ligação com as avenidas Vinte Três de Maio e dos Bandeirantes.

Já foi o aeroporto com maior tráfego de passageiros do Brasil, até a ocorrência do acidente com o Vôo TAM 3054 em julho de 2007. Foi inaugurado em 1936, e seu primeiro vôo teve como destino a cidade do Rio de Janeiro em um aeroplano da VASP. Seu nome deve-se à região em que se situa, a antiga Vila Congonhas, de propriedade dos descendentes de Lucas Antônio Monteiro de Barros, visconde de Congonhas do Campo, presidente da província de São Paulo durante período imperial. 


\subsubsection{1}

\section{Empresas Aéreas que Operam no Aeroporto e Destinos a Partir de Congonhas}

- GOL (São Paulo, Presidente Prudente, Ribeirão Preto, São José do Rio Preto, Aracaju, Belo Horizonte (CNF), Belém, Boa Vista, Brasília, Campo Grande, Cuiabá, Curitiba, Florianópolis, Fortaleza, Goiânia, João Pessoa, Macapá, Maceió, Manaus, Natal, Palmas, Porto Alegre, Porto Velho, Rio de Janeiro (GIG), Rio de Janeiro (SDU), Recife, Rio Branco, Salvador, São Luís, Teresina, Vitória, Campina Grande, Caxias do Sul, Chapecó, Foz do Iguaçu, Ilhéus, Imperatriz, Joinville, Juazeiro do Norte, Londrina, Marabá, Maringá, Navegantes, Petrolina, Porto Seguro, Uberlândia)

- OceanAir (São Paulo, Araçatuba, Belo Horizonte (CNF), Brasília, Campo Grande, Cuiabá, Curitiba, Florianópolis, Fortaleza, Goiânia, João Pessoa, Palmas, Porto Alegre, Porto Velho, Recife, Salvador, São Luís, Teresina, Araguaína, Cascavel, Chapecó, Ilhéus, Ipatinga, Ji-Paraná, Montes Claros, Passo Fundo, Petrolina, Uberaba, Vitória da Conquista)

- Pantanal Linhas Aéreas (São Paulo, Araçatuba, Bauru, Marília, Presidente Prudente, Juiz de Fora, Mucuri)

- TAM (São Paulo, Presidente Prudente, Ribeirão Preto, São José do Rio Preto, Aracaju, Belo Horizonte (CNF), Belém, Boa Vista, Brasília, Campo Grande, Cuiabá, Curitiba, Florianópolis, Fortaleza, Goiânia, João Pessoa, Macapá, Maceió, Manaus, Natal, Palmas, Porto Alegre, Porto Velho, Rio de Janeiro (GIG), Rio de Janeiro (SDU), Recife, Rio Branco, Salvador, São Luís, Teresina, Vitória, Campina Grande, Caxias do Sul, Chapecó, Foz do Iguaçu, Ilhéus, Imperatriz, Joinville, Juazeiro do Norte, Londrina, Marabá, Maringá, Navegantes, Petrolina, Porto Seguro, Uberlândia)

- VARIG (Belo Horizonte (CNF), Brasília, Curitiba, Florianópolis, Porto Alegre, Rio de Janeiro (GIG), Rio de Janeiro (SDU), Recife, Salvador, Fernando de Noronha). 
A tabela abaixo representa o movimento total de passageiros e conexão nos anos de 2006 e 2007.

Tabela 3.1 - Movimentos de Passageiros de Conexão

\begin{tabular}{|l|c|c|c|c|c|c|c||}
\hline Aeroportos & $\begin{array}{c}\text { Movimento } \\
\text { Pax 2006 }\end{array}$ & $\begin{array}{c}\text { Conexão } \\
\mathbf{2 0 0 6}\end{array}$ & $\begin{array}{c}\text { Variação } \\
\text { Conexão I I } \\
\text { Pax 2006 (\%) }\end{array}$ & $\begin{array}{c}\text { Movimento } \\
\text { Pax 2007 }\end{array}$ & $\begin{array}{c}\text { Conexão } \\
\mathbf{2 0 0 7}\end{array}$ & $\begin{array}{c}\text { Variação } \\
\text { Conexão/ } \\
\text { Pax 2007 } \\
\mathbf{( \% )}\end{array}$ & $\begin{array}{l}\text { Classificação } \\
\text { Hub and Spoke }\end{array}$ \\
\hline $\begin{array}{l}\text { Congonhas } \\
\text { SBSP }\end{array}$ & 18.459 .191 & 1.904 .962 & 10,32 & 15.244 .401 & 1.075 .845 & 7,06 & $\begin{array}{c}\text { MÉDIO } \\
\text { PEQUENO }\end{array}$ \\
\hline $\begin{array}{l}\text { Brasília } \\
\text { SBBR }\end{array}$ & 9.699 .911 & 1.518 .352 & 15,65 & 10.039 .794 & 1.806 .313 & 17,99 & $\begin{array}{c}\text { PEQUENO } \\
\text { MÉDIO }\end{array}$ \\
\hline $\begin{array}{l}\text { Guarulhos } \\
\text { SBGR }\end{array}$ & 15.759 .181 & 1.092 .475 & 6,93 & 16.963 .186 & 991.576 & 5,85 & PEQUENO \\
\hline $\begin{array}{l}\text { Galeão } \\
\text { SBGL }\end{array}$ & 8.856 .527 & 332.923 & 3,76 & 9.266 .519 & 578.200 & 6,24 & $\begin{array}{c}\text { NON-HUB } \\
\text { PEQUENO }\end{array}$ \\
\hline $\begin{array}{l}\text { Confins } \\
\text { SBCF }\end{array}$ & 4.176 .992 & 120.725 & 2,89 & 4.340 .129 & 163.360 & 3,76 & NON-HUB \\
\hline \hline
\end{tabular}

Analisando a tabela podemos afirmar que os aeroportos pesquisados segundo FAA, estão classificados da seguinte forma:

O aeroporto de Confins ficou com o número de passageiros abaixo de 355.149, portanto, sendo classificado como Non Hub. O aeroporto de Congonhas no ano de 2006 atingiu o número de passageiros de conexão 1.904.962, sendo enquadrado naquele ano como um Médio Hub. Já no ano de 2007 caiu para 1.075.845 passageiros de conexão ficando com Pequeno Hub. Guarulhos atingiu nos anos de 2006 e 2007 as seguintes quantidades de passageiros de conexão de 1.902 .475 e 1.115.017 respectivamente, recebendo uma classificação de Pequeno Hub. Galeão em 2007 atingiu 578.200 passando a Pequeno Hub.

A caracterização de aeroportos hub e non hub, tanto no Brasil quanto no exterior, é definida pelos parâmetros do FAA que classifica um aeroporto hub pelo quantitativo de passageiros em conexão. Baseado no conceito e classificação do FAA para Aeroporto hub, e nas análises realizadas com relação aos aeroportos brasileiros administrados pela Infraero, entende-se que os aeroportos de Brasília, Galeão, Guarulhos, Congonhas e Confins, apresentam potencial para operação no sistema hub and spoke. 


\section{OPERAÇÃO DE AEROPORTO HUB DO PONTO DE VISTA ECONÔMICO}

\section{1}

INTRODUÇÃO

O Governo Federal, visando transformar os aeroportos como promotores da competição e multiplicadores da economia, cria condição favorável à aplicação do conceito hub, isto deverá modernizar o atual sistema, tanto política como organizacional, administrativa e economicamente. Nesse cenário a ser atingido em um breve futuro, o mercado doméstico do transporte aéreo continuaria o processo de desregulamentação, bem como seria possível iniciar a privatização, a "estadualização" ou municipalização das administrações ou da própria infra-estrutura aeroportuária federal (Paes, 1999).

Neste novo ambiente, conseguindo atuar como um verdadeiro pólo de eficiência administrativa, ao oferecer o hub, o aeroporto poderá contribuir com o crescimento do mercado de viagens aéreas, na forma de promotor da competição entre as empresas. Além disso, ele poderá influenciar as economias locais, regionais e nacionais de uma forma muito mais positiva, ampla e dinâmica do que se atuar ineficiente, limitado ou dependente da movimentação de passageiros, aeronaves e da locação de áreas estritamente de uso aeronáutico.

\section{2 \\ AEROPORTOS COMO AGENTES DE COMPETIÇÃO ENTRE EMPRESAS AÉREAS}

Num ambiente futuro, onde haja não apenas a modernização das legislações, mas, principalmente, com a entrada de novas empresas no mercado, os aeroportos, uma vez também com suas administrações modernizadas e descentralizadas, atuariam como elementos a promover ou garantir uma maior competição entre as empresas. Como bens públicos, os aeroportos deverão garantir a possibilidade de acesso às novas entrantes, quer através de espaços nos terminais, quer em relação a uma maior capacidade do sistema de pistas (Lessa, 2002).

Entretanto, apenas espaço físico não basta. Prover tanto as incumbentes como as novas entrantes com acesso rápido, eficiente e no horário que melhor as convier (FAA, 1999). 
Este último caso, entretanto, deverá ser coordenado com a autoridade de proteção ao vôo, uma vez que espaços aéreos congestionados deverão ser observados, mas que, da mesma forma, devem sofrer otimização quanto à sua utilização. Para isso, com uma concepção mais "individualizada", as administrações deverão operar, manter e planejar a sua infra-estrutura realmente voltada à economia local, regional, nacional e ao usuário (passageiros, empresas aéreas).

Como formas complementares de promover a competição, as novas administrações deverão atentar para não criarem parcerias com empresas aéreas que limitem a capacidade do aeroporto, tanto no lado ar como no lado terra. Contratos de aluguéis ou cessões de espaços com cláusulas de exclusividade e de muito longo prazo devem ser evitados, a fim de procurar garantir a não-monopolização ou a não ocorrência de alguma forma de grande dependência do aeroporto com uma empresa aérea ou uma aliança de empresas (McKenna, 1999). O mesmo aplica-se a contratos com prestadores de serviços de rampa, handling, catering, agentes de carga, distribuidoras de combustíveis, locadoras de automóveis, etc.

\section{AEROPORTOS COMO INDUTORES DO CRESCIMENTO ECONÔMICO}

Os aeroportos são os maiores portões de entrada para a indústria do turismo. Mesmo para residentes de países vizinhos, o aeroporto desempenha papel fundamental na recepção desses turistas. Fora isso, a maior parcela do volume de cargas de alto valor agregado e de outras que necessitam de extrema rapidez e segurança no transporte é movimentada via aérea. Desta forma, aqueles mesmos aeroportos por onde chegam e partem milhões de turistas nacionais e estrangeiros também atuam como terminais de entrada, saída e distribuição destas mercadorias. Neste sentido, a presença e o desenvolvimento de uma infra-estrutura aeroportuária têm um significado de destacada importância no que tange à geração de empregos, renda e impostos para a região na qual aquela está inserida (Palhares e Espírito Santo Jr., 1999). Então, apenas de posse do conhecimento da sua área de influência, das características e potencialidades desta é que as novas administrações aeroportuárias brasileiras poderão aproveitar o grande potencial que encerra a infra-estrutura de serviços concessionada. 
Independentemente do tipo de descentralização administrativa a ser deflagrado pelo Governo Federal, poderá haver uma competição entre os próprios aeroportos.

Além da atual forma de competição indireta, através de menores impostos sobre combustíveis num ou outro estado e outros incentivos não-aeronáuticos, as novas administrações, com seus serviços e suas áreas de influência sócio-econômica diferenciadas, deverão incorrer em alguma forma de competições diretas através das presenças de empresas aéreas ou alianças internacionais. Isso pode vir a se tornar realidade entre o Rio de Janeiro e São Paulo, entre os aeroportos das três capitais dos estados do Sul e entre Salvador, Recife e Fortaleza, no Nordeste. Ressalte-se, porém, que uma competição direta apenas será possível caso os aeroportos exemplificados venham a ser administrados por consórcios empresariais distintos (dentro da sua região), ou por seus estados e/ou municípios.

\subsection{DIVERSIDADE COMERCIAL NOS AEROPORTOS}

Há alguns anos que os aeroportos em todo o mundo não são mais tidos apenas como meros provedores de infra-estrutura para as empresas aéreas. Seus terminais e áreas diversas passaram a ser utilizados como locais de investimentos em serviços e comércio, atendendo não apenas àqueles que fazem uso do transporte aéreo, mas, sobretudo, a toda a região de influência do aeroporto (Palhares, 2006).

Mais do que simplesmente comparar dois aeroportos brasileiros com alguns poucos do exterior, o presente trabalho ressalta a necessidade de promover a discussão pública acerca da atual e futura política aeroportuária brasileira. Com isso, visar-se-ia, sobretudo, a melhoria do modelo administrativo atual e o monitoramento das práticas administrativas futuras, por intermédio da proposição do uso de indicadores de desempenho. Para tal, é importante que se tenha uma divulgação ampla e irrestrita dos dados, informações e análises dos aeroportos nacionais, uma vez que são, de fato, bens públicos. Não obstante, a nova Agência reguladora deveria promover a elaboração de estudos e análises quantitativos e qualitativos, tendo sido um breve exemplo aqui apresentado, a fim de que se possa, ao comparar a realidade brasileira com a de outros países, melhor avaliar a qualidade, eficiência e os custos dos serviços sendo prestados à população. 
De posse desses e de outros indicadores de eficiência e produtividade, o Governo Federal, na forma da nova Agência reguladora, bem como a sociedade como um todo, deverão estar em condições de não apenas monitorar as possíveis novas concessionárias, mas como, principalmente, de impor níveis de excelência para que a iniciativa privada e/ou as administrações públicas atinjam, visando o atendimento ao cidadão. É sob esta nova realidade que o novo modelo de administração de aeroportos no Brasil deverá ser regido.

\section{5}

\section{A ECONOMIA AEROPORTUÁRIA E O SISTEMA HUB}

O aeroporto que opera principalmente como hub and spoke, não tendo grande número de demanda de vôos locais, não quer dizer necessariamente que terá uma baixa receita, pois, apesar de ter menor demanda comercial referente às tarifas de embarque e comércio instalado nas áreas públicas do aeroporto, por outro lado, o grande número de aeronaves proporciona uma receita satisfatória para o aeroporto hub por meio de outras fontes, conforme descrito abaixo:

- Tarifas aeronáuticas.

- Tarifas de posusos e decolagens de aeronaves.

- Serviço de reabastecimento de aeronaves.

- Permanência de estadia de aeronaves em solo.

- Serviços de bordo (catering).

- Serviços de apoio de solo (ESATA).

- Áreas comerciais instaladas nas salas de embarque que poderão atender aos passageiros de conexão.

- Disponibilização de porão de aeronaves para transporte de carga aérea.

- Geração de receita interna para o aeroporto por meio da própria comunidade aeroportuaária local.

- Receita de tarifa de embarque de passageiros quando da conexão de vôo doméstico para internacional. 
A atividade fim no gerenciamento da rede de linhas de uma empresa aérea é a maximização do seu resultado por meio da combinação de forma otimizada da oferta de vôos com a demanda dos passageiros. Apesar da utilização de softwares específicos baseados em modelos matemáticos complexos, a programação de vôos no Brasil ainda é realizada de forma empírica em função da visão de seus planejadores, sendo assim, pouco sistemática e limitada quanto à previsão de seus resultados (Lessa, 2006).

O principal produto de uma companhia aérea são os assentos oferecidos em suas aeronaves. Os assentos têm como característica o fato de serem perecíveis; apesar de não perecerem de maneira semelhante aos alimentos, podem ser irrecuperavelmente perdidos se, por exemplo, um vôo decolar com assentos vazios. Os vôos de uma empresa aérea são inter-relacionados, visto que alterações na programação de um vôo específico refletem em outros vôos da rede.

As questões centrais nessa programação são: a concentração no preço e no produto, a consideração da oferta dos competidores, a causalidade entre o aumento da oferta e o aumento da demanda, e que a rede de linhas é o resultado da combinação eficiente entre a oferta e a demanda. É preciso ressaltar que a programação de vôos ou scheduling está integrada com o planejamento corporativo da companhia aérea, de forma a atender as suas estratégias competitivas. Desta forma, metas orçamentárias, de participação no mercado e de aquisição de aeronaves, dentre outras, devem ser levadas em consideração. A programação deve ser tão acurada quanto o possível para que, por exemplo, a frota da empresa não seja mal dimensionada. Ao subdimensioná-la, não haverá aeronaves suficientes para atender à demanda de vôos; ao contrário, o excesso de vôos programados resultará em subutilização da frota e prejuízo financeiro (Freitas, 2006). 

EMPRESA AÉREA

O programador deve criar um equilíbrio entre objetivos conflitantes para que a partir de uma ótica comercial a programação mais produtiva seja alcançada. O equilíbrio deve ser criado enquanto opera-se com restrições financeiras, técnica e operacionais.

Os objetivos, de forma balanceada, são os seguintes:

\section{a) Satisfação do cliente}

São necessárias informações sobre o cliente para acomodar as preferências, as necessidades e os desejos dos passageiros. O plano de programação deve tentar satisfazer os passageiros considerando a hora, o dia da semana, a freqüência com que os vôos operam etc.

\section{b) Produtividade dos recursos humanos}

O programador de vôos deve dimensionar a mão-de-obra de forma a não subutilizá-la.

Considerando-se que um dos principais itens de custo operacional refere-se à remuneração dos aeronautas (comandante, co-piloto e comissários) a alocação ótima desses recursos em consonância com a atividade de escala de tripulantes é de fundamental importância.

\section{c) Alta utilização da frota}

A respeito da utilização da aeronave, uma das questões mais importantes é que uma aeronave só dá lucro quando está voando, pois enquanto está no solo está ociosa (como uma máquina parada em uma indústria). Uma maneira de elucidar isto é que os custos indiretos de operação (leasing, depreciação, seguros) são relativamente fixos. Conseqüentemente, conforme a utilização aumenta, os custos indiretos por total de horas operadas decrescem. Isto se deve a uma razão - se uma rede de linhas é constituída principalmente por long haul routes (rotas de longa escala), haverá alta utilização por aeronave. Isto se deve ao fato de que vôos de curta distância resultam em uma alta proporção de tempo ocioso (tempo em que a aeronave está no solo) comparado ao tempo de 
vôo. Isto significa que a disponibilidade total da aeronave diminui, e a utilização da frota reduz-se

Outro motivo pelo qual long haul routes aumentam a utilização de uma aeronave é que o transporte de longa escala (long haul carriers) podem voar à noite, enquanto vôos de pequenas distâncias são feitos principalmente durante o dia.

\section{d) Altos load factors (taxas de ocupação)}

Um outro objetivo da programação de vôos é atingir um bom equilíbrio entre: a) o nível de tráfego disponível e b) o nível de capacidade oferecida. A companhia deseja alcançar load factors bastante altos, mas que devem ser ao mesmo tempo realísticos. De outro modo, a companhia acabaria empurrando os seus clientes para o competidor. Load factors estabelecidos em um nível demasiadamente alto resultam na situação em que os passageiros acham que não vão conseguir assentos para o vôo que querem e acabam optando por uma alternativa.

\section{e) Alta freqüência}

A experiência industrial sugere que uma empresa aérea pode obter uma fatia significativa do mercado (talvez até, o domínio do mercado) mais em função da alta freqüência de seus vôos do que do nível de capacidade oferecido em determinada rota. Isto parece contraditório com o que foi supracitado em relação ao load factors. Obter o equilíbrio adequado entre os dois fatores é a tarefa do programador de vôos. Também deve ser observado, que em certas circunstâncias, um mínimo de freqüência deve ser garantido aos clientes (em rotas utilizadas por executivos como a Ponte Aérea RJ/SP, por exemplo). Ao tratar de criar e manter o equilíbrio entre altas freqüências e altos load factors, o programador deve lembrar-se das restrições quanto à capacidade da aeronave e à frota disponível.

\section{f) Maximização das conexões}

Um outro objetivo que deve ser alcançado pela programação de vôos é a otimização das conexões de passageiros nas duas pontas de uma dada rota. A elaboração de hubs de conexões tem sido desenvolvida por várias 
transportadoras com este objetivo em mente. Com um relatório de movimento de aeroportos, pode-se observar quais os vôos que chegam e quais os que partem de determinada localidade. A partir de então, considerandose a restrição de tempo mínimo de conexão (MCT) do aeroporto em estudo, o tempo máximo que o passageiro admitiria esperar por uma conexão, além de outras restrições são montadas as possíveis conexões entre os vôos e as necessárias alterações na malha.

\section{g) Sincronização consistente}

Isto se chama clockface timing. Conforme a companhia aérea elabore um catálogo básico de programação de vôos, a consistência ajudará a criar familiaridade e lealdade com o cliente. Isto é válido não apenas para agentes de viagem como para o público em geral. Infelizmente, devido às restrições de programação, pode ser inviável para uma linha aérea manter tal consistência.

\section{3 RESTRIÇÕES À PROGRAMAÇÃO DE VÔOS}

\subsection{1}

Restrições Externas: Problemas de Slot

Os aeroportos vêm experimentando de forma crescente os congestionamentos, ou seja, o volume de tráfego à espera de decolagem e pouso em um determinado aeroporto excede a capacidade da sua pista de decolagem. Os aeroportos de Congonhas e Guarulhos em São Paulo, além do Santos Dumont, no Rio de Janeiro e do aeroporto de Brasília já apresentam restrições quanto aos horários de partida e chegada de aerronaves (slots). Tal sistema opera com base em certos princípios. O mais importante deles é princípio de grandfather rights. Ele especifica que, se uma determinada companhia detém os slots durante uma dada temporada, estes slots continuarão alocados à mesma na temporada seguinte. Isto permite um planejamento a um prazo mais longo, mas representa uma forte restrição a mudanças significativas e repentinas na programação de vôos. 


\subsection{2}

Night Curfews

Muitos aeroportos ficam fechados ou reduzem bastante o tráfego durante a noite. Isto implica em restrições para o programador de vôos, uma vez que ele não deve programar decolagens ou aterrissagens nestes aeroportos durante este horário.

\subsubsection{Regulamentação do Setor}

Em certos casos, o governo concede direitos exclusivos a uma única companhia para operar em determinada rota.

\subsubsection{Acordos de Pools/Joint-Ventures}

Ocasionalmente, as companhias aéreas formam joint ventures, que cobrem vastas áreas.

\subsubsection{Manutenção de Aeronaves}

A manutenção de aviões que operam em um aeroporto é geralmente fornecida pela maior linha aérea em operação no aeroporto ou por companhias especializadas, no caso de aviões de passageiros. Cabe ressaltar que embora muitos aeroportos possuam serviços básicos de manutenção, apenas parte deles oferecem serviços mais especializados e complexos, isso em um aeroporto $h u b$ é preponderante em função da grande quantidade de aeronaves em operação que poderão passar por pequenos ajustes envolvendo de manutenção.

Durante o período em que a aeronave fica estacionada em solo, um check-up é realizado nas aeronaves, em busca de falhas.

\subsubsection{Restrições Internas: Requisitos de Manutenção}

Cada tipo de aeronave em uma frota tem a sua própria programação de manutenção. Devem existir intervalos na programação de vôos (de acordo com o número de horas de vôo) que permitam a manutenção preventiva da aeronave, isto é, devem ser reservados períodos de manutenção nos quais a aeronave encontra-se parada no hangar. 


\subsection{7}

Planos de Contingência

A preocupação em elaborar planos de contingência na ocorrência deste tipo de situação levou as companhias aéreas a investirem em programas de computadores capazes de verificar a confiabilidade e pontualidade de um plano com base na comparação entre programações prescritas e reais do passado que estão armazenadas em bancos de dados.

Por motivos de atraso de vôo algumas companhias mantêm planos de contingência para manter a pontualidade do restante do planejamento. Às vezes, uma ou mais aeronaves são deixadas de reserva em caso de ocorrência de problemas. Vários fatores influenciam o nível de reserva necessário para cobrir problemas com a frota, incluindo a situação financeira da companhia, as condições e idade da sua frota, a competitividade no mercado etc.

\section{4}

REQUISITOS OPERACIONAIS GERAIS

Para que uma linha aérea seja capaz de manter um nível operacional satisfatório é preciso que estes requisitos operacionais sejam cumpridos: turnaround times, folga da tripulação, tempo para limpeza e catering (abastecimento de gêneros alimentícios) da aeronave etc.

\subsubsection{Empresas Aéreas e Seus Principais Hubs pelo Mundo}

Aerolíneas Argentinas: A Aerolíneas Argentinas é a maior companhia aérea da Argentina, tanto em vôos internacionais como domésticos. Além disto, é responsável por cerca de $80 \%$ dos vôos domésticos e $40 \%$ dos internacionais que partem do Aeroporto Ministro Pistarini, localizado na região de Ezeiza - Buenos Aires. Em 1949 as companhias aéreas argentinas se fundiram para a criação da Aerolineas Argentinas. A empresa começou a operar em 7 de dezembro de 1950. Sua frota em 2006 era de 59 aviões voando para 55 destinos, e não havia nenhum acordo com outras cias aéreas. Um detalhe interessante é que a Aerolíneas Argentinas e a LAN Airlines são as únicas empresas latino-americanas que voam para a Oceania.

Aeroméxico: A AeroMéxico, é a maior companhia aérea do México. Durante mais de 10 anos consecutivos foi considerada a companhia aérea mais pontual. Opera mais de 400 vôos diários, ou 750 junto com Aerolitoral (uma coligada) voando para 60 destinos, 39 no México, 
15 na América do Norte, 3 na América do Sul, 2 na Europa e 1 na Asia. Sua base principal é o aeroporto Aeroporto Internacional Benito Juárez da Cidade do México. A Aero México é membro da Sky Team Alliance, e sua frota em 2006 era de 77 aviões.

Air Canadá: A Air Canada é a maior companhia aérea do Canada, e está entre as 20 maiores do mundo em número de passageiros transportados anualmente. A Air Canada emprega mais de 32 mil pessoas, atendendo uma média de 29 milhões de passageiros por ano, em mais de 170 destinos. O principal centro de operações da Air Canada é o Aeroporto Internacional Pearson Toronto, em Ontário, enquanto a sede da empresa está localizada em Montreal, Quebec. É considerada uma das linhas aéreas mais seguras do mundo. A Air Canada é um membro fundador da Star Alliance, e sua frota em 2006 era de 297 aviões.

Air Europa: A Air Europa Líneas Aéreas é uma companhia aérea espanhola fundada em 1986, com sede na cidade de Palma de Mallorca e sua base de operações é o Aeroporto MadridBarajas. Possui Boeings 737-800, Boeings 767 e Airbus A330, que voam para 38 destinos. Em 2006 sua frota era de 37 aviões.

Air France: A Air France (Compagnie Nationale Air France) é uma subsidiária da Air FranceKLM. A Air France foi fundada em 1933, e é a maior companhia aérea da França. Emprega mais de 70.000 pessoas, voando para 186 destinos e têm como base principal o aeroporto de Paris Charles de Gaulle. A Air France foi criada em 1933, através da fusão de várias companhias aéreas, e juntamente com a britânica British Airways, passou a utilizar o Concorde em 1976, tendo sido parcialmente privatizada em 1999. A Air France/KLM é atualmente a terceira maior companhia aérea do mundo. É o resultado da fusão entre as duas empresas Air France e KLM, que continuam a voar nas suas próprias cores, no entanto oferecem serviços conjuntos. Em 2006 sua frota era de 362 aviões, e participa como menbro fundador da Sky Team Alliance.

Alitalia: A Alitalia é a maior companhia aérea da Itália e foi fundada em 1947. Está sediada em Roma, e as suas principais bases de operações são os aeroportos internacionais de Roma (Fiumicino) e de Milão (Malpensa)l. Possuindo mais de 100 destinos em cerca de 50 países. Em 2006 sua frota era de 152 aviões, e participa como membro da Sky Team Alliance. 
American Airlines: A American Airlines é uma companhia aérea americana.e é considerada a maior companhia aérea de passageiros do mundo, tendo a maior frota de aviões do mundo, o maior número de empregados e o maior número de passageiros movimentados por ano. Seus centros principais de operações são os aeroportos de Chicago, Dallas e Miami. A American Airlines voa para mais de 240 destinos, transportando mais de 120 milhões de passageiros por ano. Em 2006 sua frota era de 970 aviões, e participa como membro da OneWorld.

ANA: A ANA All Nippon Airways é uma empresa aérea do Japão, e a oitava maior do mundo em número de passageiros transportados. As suas operações estão concentradas no aeroporto de Narita, em Tóquio. A partir de Tóquio, a ANA atende os destinos domésticos, além de todo o Sudeste Asiático. A ANA voa para mais de 70 destinos, transportando mais de 45 milhões de passageiros por ano. Em 2006 sua frota era de 190 aviões, e participa como membro da Star Alliance.

Avianca: A Avianca é uma companhia aérea da Colômbia, sendo a mais importante do país. Criada em 1919, foi a primeira linha aérea comercial de passageiros fundada na América e a segunda no mundo. É sexta maior companhia na América Latina. Atualmente pertence ao mesmo grupo que controla a brasileira OceanAir. Em 2006 sua frota era de 49 aviões, voando para 39 destinos.

British: A British Airways é a maior companhia aérea do Reino Unido e terceira maior da Europa. É também uma das maiores companhias aéreas do mundo, com mais vôos originários da Europa para a América do que qualquer outra. Membro da Oneworld, a British Airways opera vôos para mais de 550 destinos quando se inclui compartilhamento de vôos com outras companhias aéreas, e está baseada na capital do Reino Unido, Londres, tendo a sua maior presença no aeroporto de Heathrow.

Em 2006 sua frota era de 363 aviões, voando para 210 destinos.

Continental: A Continental Airlines, ou somente Continental, é uma companhia aérea dos Estados Unidos. Baseada em Houston, no Texas, a companhia é a $5^{\circ}$ maior dos Estados Unidos e uma das maiores do mundo, transportando mais de 60 milhões de passageiros por ano. Membro da SkyTeam, a Continental opera vôos para destinos localizados na América, na 
Europa, na Ásia e na Oceania. Em 2006 sua frota era de 348 aviões, voando para 268 destinos.

Copa: A Copa Airlines é uma companhia panamenha, sendo seu hub principal a Cidade do Panamá. A companhia já oferece 14 vôos semanais entre Panamá e São Paulo, com Boeing 737-700, e 5 entre Panamá e Manaus. Em 2006 sua frota era de 28 aviões, voando para 30 destinos.

Delta: A Delta Air Lines é uma das mais importantes companhias aéreas dos Estados Unidos com sede na cidade de Atlanta. A Delta Airlines tem destinos em todo o mundo, incluindo na América do Norte e do Sul, África, na Europa, no Oriente Médio Oriente e Caribe. A companhia voa para 96 países, nos 5 continentes. Os seus maiores hubs são o Aeroporto Internacional de Atlanta e o Aeroporto Internacional John F. Kennedy. É atualmente membro da SkyTeam Alliance. Em 2006 sua frota era de 607 aviões, voando para 281 destinos, transportando mais de 100 milhões de passageiros por ano.

Ibéria: A Iberia - Líneas Aéreas de Espanha, também conhecida apenas como Iberia, é a companhia aérea nacional da Espanha, com sede em Madrid. As suas principais bases são os aeroportos internacionais de Madrid e Barcelona. Transporta mais de 30 milhões de passageiros por ano. Em 2006 sua frota era de 220 aviões, voando para 105 destinos, e participa como membro da OneWorld

JAL: A Japan Airlines é a maior companhia aérea da Ásia. A Japan Airlines Corporation controla duas companhias sob a marca JAL: Japan Airlines International que opera uma vasta linha de rotas internacionais e a Japan Airlines Domestic que liga as maiores cidades do Japão. Sua base operacional fica no Aeroporto Internacional de Tóquio, em Tóquio e no Aeroporto Internacional de Osaka em Osaka. A JAL também é dona de outras oito empresas: Harlequin Air, Hokkaido Air System, JAL Express, JALways, J-Air, Japan Air Commuter, Japan Asia Airways e Japan Transocean Air. Em 2006 sua frota era de 280 aviões, voando para 125 destinos.

KLM: A KLM Royal Dutch Airlines é uma empresa aérea dos Países Baixos (Holanda) com sede na cidade de Amstelveen e foi fundada em 1919. Atualmente é membro da SkyTeam Alliance. A empresa tem uma subsidiária, a KLM Cityhopper, que assegura as ligações de 
curta distância. Em 2006 sua frota era de 190 aviões, voando para 128 destinos, transportando mais de 20 milhões de passageiros por ano.

LAN: A LAN Airlines é uma linha aérea chilena com base em Santiago. A suas subsidiarias comprendem: Lan Airlines (Vôos internacionais com base no Santiago), Lan Express (Vôos domésticos dentro do Chile), Lan Perú (Vôos domésticos e internacionais com base em Lima), Lan Ecuador (Vôos internacionais com base na Equador) e a Lan Argentina (Vôos internacionais com base na Argentina). Em 2006 sua frota era de 48 aviões.

Lufthansa: A Lufthansa (Deutsche Lufthansa AG) é o nome da maior empresa aérea da Alemanha. A sua base principal localiza-se no Aeroporto Internacional de Frankfurt, que também é a principal área de tráfego da empresa. A empresa também possui um segundo hub no Aeroporto Internacional Franz Josef Straus em Munique. A Lufthansa é um dos membros fundadores da Star Alliance, uma das maiores alianças aéreas do mundo. Em 2006 sua frota era de 377 aviões voando para 177 destinos, transportando mais de 50 milhões de passageiros por ano.

Mexicana: A Mexicana foi fundada em 12 de julho de 1921 como Compañia Mexicana de Transportes Aéreos(CMTA) a empresa que hoje é conhecida comercialmente como Mexicana é a quarta empresa mais antiga do mundo e a segunda da América do Sul, e é a maior empresa doméstica do Mexico com 32 cidades servidas além de mais de 20 destinos nos Estados Unidos, Canadá e Américas Central e do Sul.

Qantas: A Qantas é uma empresa aérea australiana, e a terceira mais antiga do mundo, tendo sido fundada em 1920. Opera a partir do Aeroporto Internacional de Kingsford Smith e do Aeroporto de Melbourne. A Qantas e suas subsdiárias transportam mais de 30 milhões de passageiros ao ano. Em 2006 sua frota era de 219 aviões, voando para 143 destinos, sendo associada a OneWorld.

South African: A South African Airways, empresa de bandeira da África do Sul, foi criada a 1 de fevereiro de 1934. A companhia transporta mais de 7 milhões de passageiros por ano numa rede de rotas que serve 34 cidades em 26 países. Em 2006 sua frota era de 58 aviões, sendo membro associado da Star Alliance. 
Spanair: A Spanair é uma companhia aérea espanhola com sede em Palma de Mallorca tendo sido fundada em 1988, sua filosofia é a de prestar a melhor qualidade no serviço de transportes aéreos a todos os seus passageiros. Com mais de 340 vôos diários, 90 deles charter e 250 regulares, e mais de 3000 empregados, a Spanair é umas companhias dinâmicas, que tem buscado constantemente o crescimento, transportando mais de 8 milhões de passageiros por ano. Em 2006 sua frota era de 64 aviões, sendo membro associado da Star Alliance.

Swiss: A Swiss International Air Lines é uma companhia aérea com sede em Base, Suíça. É a principal companhia aérea suíça e o aeroporto base é o Aeroporto Internacional de Zurique. Opera uma frota de aviões tecnicamente avançados nas quais transporta anualmente, aproximadamente 10 milhões de passageiros. Em 2006 sua frota era de 69 aviões, sendo membro associado da Star Alliance.

TACA: A TACA foi fundada em 1931, com base na capital hondurenha, Tegucigalpa, e os vôos limitavam-se ao transporte de carga, principalmente para o governo local, utilizando-se de apenas uma aeronave. Em 1939 a empresa foi reorganizada em El Salvador, com o nome de TACA El Salvador e com sede na cidade de San Salvador. Ao final da década de 80 iniciou-se a compra de participações acionárias nas principais empresas da região: AVIATECA, LACSA e NICA, criando a base para a fundação do Grupo TACA, que hoje em dia reúne as quatro empresas sob uma mesma identidade visual. Com a integração operacional, tem ao todo 38 destinos na Américas do Sul, Central, México e Estados Unidos. Em 2006 sua frota era de 36 aeronaves.

TAM : TAM Linhas Aéreas (www.tam.com.br) lidera o mercado doméstico desde julho de 2003 e fechou o último mês de dezembro 2008, com 48,6\% de market share. A companhia voa para 47 destinos no Brasil. Com os acordos comerciais firmados com companhias regionais, chega a 81 destinos diferentes do território nacional. A participação de mercado da TAM entre as companhias aéreas brasileiras que operam linhas internacionais foi de $70 \% \mathrm{em}$ dezembro. As operações para o exterior abrangem vôos diretos para onze destinos: Nova York e Miami (EUA), Paris (França), Londres (Inglaterra), Milão (Itália), Frankfurt (Alemanha), Madri (Espanha), Buenos Aires (Argentina), Santiago (Chile), Caracas (Venezuela) e Montevidéu (Uruguai). Com a TAM Mercosur, atende ainda Assunção e Ciudad del Este (Paraguai), Córdoba (Argentina), Santa Cruz de la Sierra e Cochabamba (Bolívia), entre outras cidades na América do Sul. Além disso, mantém acordos de codeshare 
que permitem o compartilhamento de assentos em vôos com companhias internacionais, possibilitando ao passageiro viajar para outros 62 destinos nos EUA, América do Sul e Europa. Pioneira no lançamento de um Programa Fidelidade para empresa aérea no Brasil, a TAM possui hoje 4,3 milhões de associados e já distribuiu mais de 5 milhões de bilhetes por meio de resgate de pontos.

TAP: A TAP Portugal (Transportes Aéreos Portugueses) é a principal companhia de linha aérea de Portugal. Foi fundada em 14 de Março de 1945. O seu hub em Lisboa é uma portachave para a entrada e saída da Europa e um cruzamento para continentes como África, América do Norte e América do Sul. A actual rede da TAP inclui 42 destinos em 25 países na Europa e em África, bem como na América do Norte, Central e do Sul, transportando mais de 6 milhões de passageiros por ano. Em 2006 sua frota era de 44 aeronaves, e é membro da Star Aliance.

United: A United Airlines é a segunda maior linha aérea dos Estados Unidos e do mundo, empregando aproximadamente 80 mil trabalhadores. Seu principal centro de operações é o Aeroporto Internacional de Chicago (O'Hare). A United opera para 208 destinos, transportando mais de 70 milhões de passageiros por ano. Em 2006 sua frota era de 455 aeronaves, e é membro fundador da Star (IATA, 1992).

\section{5}

IMPLICAÇÕES NEGATIVAS NO HUB

Adotando o Brasil como exemplo, onde a alta temporada de viagens aéreas começa com as festas de fim de ano e vai até o Carnaval, apresenta-se como principais fatores negativos os atrasos que geraram novas medidas do governo. No ano passado, esse foi um período de sofrimento para quem quis embarcar em qualquer aeroporto brasileiro. A primeira medida prevê que as companhias aéreas deverão pagar multas para os passageiros em caso de atraso. A segunda deverá aumentar os valores das tarifas pagas pelas empresas para deixar as aeronaves paradas entre pouso e decolagem nos aeroportos de Guarulhos e Congonhas, no Estado de São Paulo. "A idéia é que as empresas façam uso racional dos aeroportos”, diz o ministro da Defesa, Nelson Jobim.

São duas medidas disciplinadoras. Mas seus efeitos podem ser mais maus que bons. Dificilmente o drama nos aeroportos será evitado nas próximas semanas - e é provável que as 
companhias reajustem o preço das passagens. Para entrar em vigor, a proposta de ressarcimento do bilhete depende de regulamentação, o que deverá levar mais de 30 dias. A outra medida ainda passará por uma consulta pública. Na melhor das hipóteses, estará valendo em março, depois do Carnaval e da alta estação nos aeroportos.

Segundo especialistas, o que o governo propõe, na prática, é reduzir a demanda pelo caminho do encarecimento das passagens. "Esse sistema deve acabar com a democratização por que passou o setor nos últimos anos", diz o consultor Gianfranco Beting, especialista em aviação. Os próprios executivos do setor anunciaram na semana passada que o aumento nas taxas deverá ser repassado para o consumidor. "As companhias aéreas operam com margens de lucro muito baixas e não vão arcar com esses custos", diz o consultor André Castellini, especialista em aviação da Bain \& Company. Para Jobim, só as companhias ineficientes vão repassar custo para os passageiros. "Nesse caso, o mercado resolve", diz o ministro.

A compensação financeira pelos atrasos tem um mérito, que é criar um mecanismo legal de defesa para o consumidor. Cabe ao passageiro escolher se quer receber a indenização em dinheiro, milhagens ou créditos da companhia. O prazo para a empresa ressarcir o cliente é de 30 dias. Nos Estados Unidos, há um projeto semelhante. Recentemente, o presidente George W. Bush propôs aumentar de US\$ 400 para US\$ 800 a indenização paga aos passageiros cujos vôos sofrem um atraso de mais de duas horas. A diferença é que eles vão além. A companhia que administra os aeroportos de Nova York, os principais causadores dos atrasos, está preparando a expansão das pistas do aeroporto de Stewart International. As medidas anunciadas por Jobim geraram dúvidas em relação ao próprio funcionamento. Não está claro, por exemplo, como o governo pretende detectar os reais responsáveis pelos atrasos dos vôos, já que as companhias só terão de pagar por aqueles atrasos dos quais serão julgadas responsáveis. "Criar um sistema de identificação eficiente e justo demandará esforços gigantescos e, ainda assim, sua eficácia seria duvidosa”, diz Castellini. Para resolver o problema, afirmam especialistas, é necessário investir em infra-estrutura (Neves, 2007). 
Milhas pelo atraso

Quanto as empresas

aéreas deverăo pagar

aos clientes pela

demora dos vôos - em

$\%$ do valor do bilhete

Até 30 minutos

De 31 minutos a 1 hora

De 1 hlmin a 2 horas

De $2 \mathrm{hlmin}$ a 3 horas

De $3 \mathrm{hlmin}$ a 4 horas

De 4 hlmin a 5 horas

Acima de 5 horas

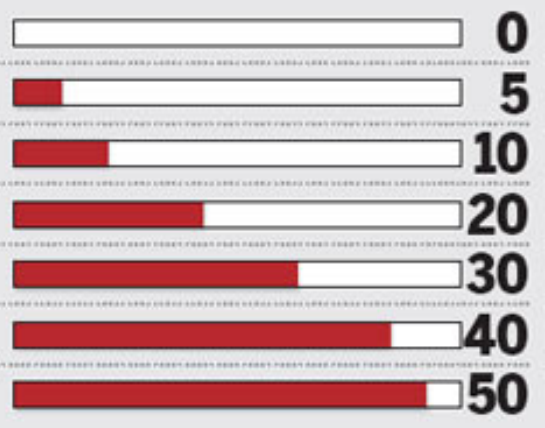

Figura 5.1 - Punições por Atraso das Cias Aéreas

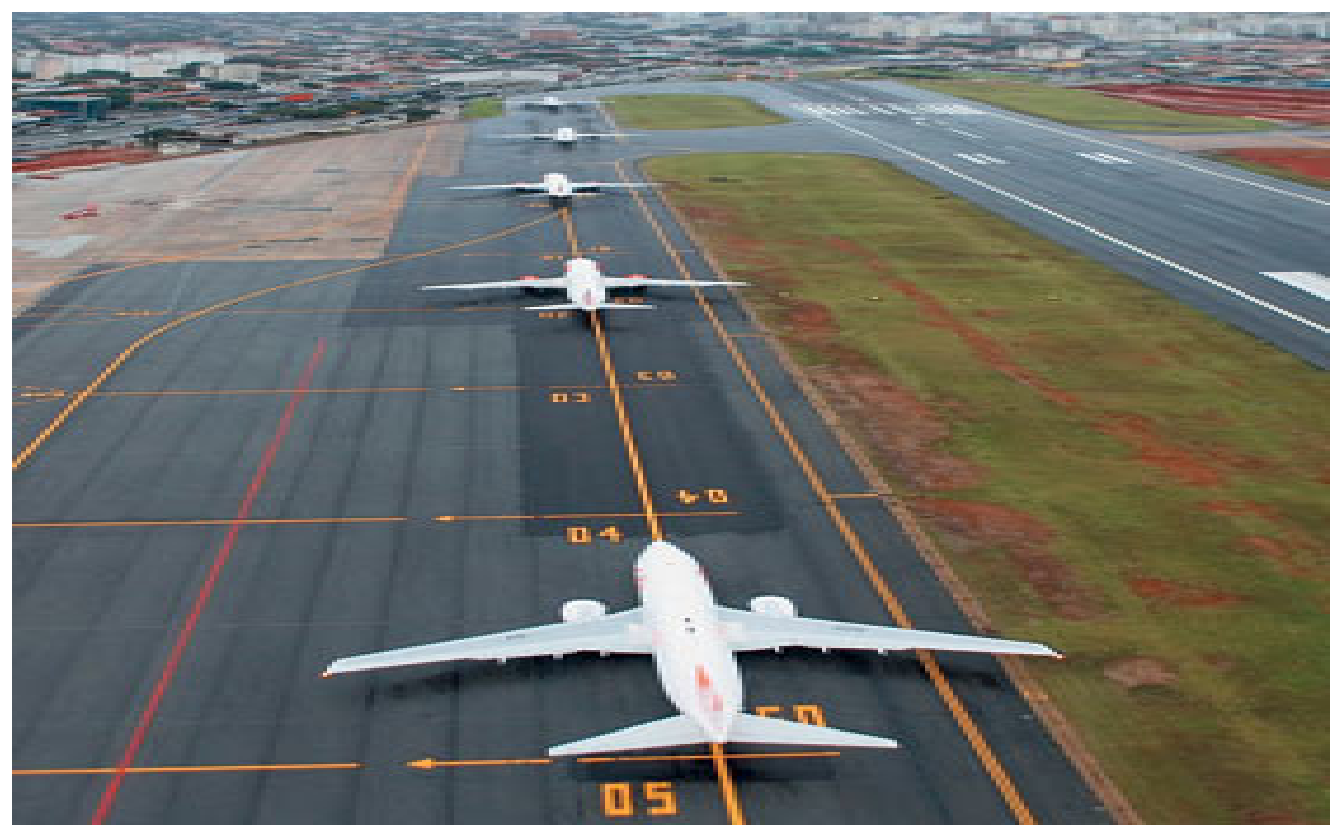

Figura 5.2 - Aeroporto de Congonhas 
6.1

\section{INTRODUÇÃO}

Este capítulo trata da infra-estrutura aeronáutica, aeroportuária e das condições de aumento de suas capacidades, pois, sem este potencial de ampliação, a operação segundo o conceito hub estará prejudicada.

\section{2}

\section{TRÁFEGO AÉREO}

Para operar em um sistema hub é necessário à preparação de infra-estrutura de controle de espaço aéreo, com potencial de aumento da segurança por meio de informações de posição de aeronaves mais exata e de melhores comunicações. A utilização de ligações para transmissão de dados permite igualmente às companhias aéreas e a outros operadores obterem dados operacionais a partir dos aviões em vôo. Estes sistemas facilitarão a adoção das soluções "vôo livre", que permitem determinadas funções de gestão de tráfego aéreo a partir do cockpit. As operações aeroportuárias exigem uma melhor integração e uma gestão das informações que permita aos vários controladores envolvidos nas diferentes fases de vôo trocarem dados e preverem as suas operações e os movimentos de aviões. Estes sistemas de gestão e planificação, assim como os sistemas avançados de orientação e de autorização de tráfego na área de movimento nos aeroportos, melhorarão a capacidade destes, especialmente em situação de mau tempo, reduzindo a pressão sobre os controladores do tráfego aéreo.

A boa utilização das novas tecnologias de eletrônica digital é essencial para aumentar o espaço aéreo disponível e permitir uma gestão eficiente. No passado, as decisões de investimento nos sistemas inteligentes foram muitas vezes tomadas com base em interesses industriais nacionais, tendo como resultado a restrição da compatibilidade técnica ou operacional dos centros e uma interoperabilidade limitada. Esta insuficiente interoperabilidade tem como conseqüência reduzir gravemente a eficácia e implicar custos suplementares, desde a fragmentação da formação profissional dos controladores até grandes dificuldades de coordenação operacional, passando por custos acrescidos de investimento e de manutenção. 
Um aeroporto é uma área com a infra-estrutura e os serviços necessários para o atendimento de pousos e decolagens de aviões. Um pequeno aeroporto é muitas vezes referido por campo de aterrisagem (ou simplesmente campo) ou aeródromo. Também pode ser referido como base aérea, quando o aeroporto está designado a servir primariamente aviões militares.

Para preparar aeroportos para operar no sistema hub and spoke a acessibilidade precisa ser de fácil planejada, as estradas para o transporte de passageiros, trabalhadores e carga do aeroporto a outras cidades. Para esse fim, alguns aeroportos também possuem acesso a ferrovias (carga), metrô e ferries (passageiros). Além disso, aeroportos movimentados possuem equipes de emergência como bombeiros e pronto-socorros, para a eventualidade de um acidente; aeroportos maiores chegam a possuir hospitais completos.

Aeroportos podem ocupar grandes espaços, chegando por vezes a ocupar mais de 120 km; um grande centro aeroportuário pode empregar diretamente mais de 20 mil pessoas, movimentar centenas de aeronaves, manejar centenas de toneladas de carga aérea e várias dezenas de milhares de passageiros num único dia de operação. SATURAÇÃO DA INFRA-ESTRUTURA AEROPORTUÁRIA

O sistema de infra-estrutura aeroportuária brasileira pode entrar em colapso caso não sejam acelerados investimentos e encontradas soluções para terminais que já superaram a capacidade de operação ou estão à beira da saturação, o que já acontece com Congonhas e Brasília e, no cenário nacional até o ano de 2015, tingirá 20 dos 28 principais aeroportos do país.

A capacidade de abrigar passageiros nesses aeroportos será superada pela demanda por transporte aéreo, que cresce a taxas chinesas - próximas de $20 \%$ nos últimos quatro anos. Até 2025, também os pátios de aeronaves estarão comprometidos em 20 aeroportos. O diagnóstico - que não menciona explicitamente um colapso no sistema - faz parte de relatório da ANAC que está em fase de preparação e cuja versão preliminar foi entregue à CPI do Apagão Aéreo da Câmara em outubro de 2007.

Nem mesmo os recursos do PAC serão suficientes para fazer frente ao aumento da demanda. A Infraero aponta a necessidade de investimento total de $\mathrm{R} \$ 5,069$ bilhões, entre 2007 e 2010 , 
nos 28 aeroportos analisados. Para a ANAC, há necessidade de recursos adicionais de R\$ 1,771 bilhão. Adequar os aeroportos à nova realidade da aviação no país, porém, esbarra na falta de orçamento. Em receita própria, a Infraero terá apenas R \$ 3,044 bilhões para investir no quadriênio. Esses recursos serão complementados pelo PAC, que destinará mais R\$ 2 bilhões do Orçamento Geral da União para 20 aeroportos. O problema é que, mesmo assim, o recurso não chega nem perto do total necessário: $\mathrm{R} \$ 6,8$ bilhões, segundo as estimativas da ANAC.

Há um claro e preocupante descompasso entre o crescimento da demanda por transporte aéreo e os investimentos realizados para fazer frente aos desafios de um setor altamente dinâmico", diz a ANAC no estudo, que dará subsídios para a elaboração de um Plano Aeroviário Nacional, em 2008. O PAN vai orientar os investimentos de longo prazo na infra-estrutura aeroportuária.

A situação mais dramática está em São Paulo. Além da absoluta saturação do terminal de passageiros de Congonhas, que já recebe mais de 17 milhões de pessoas para uma capacidade instalada de 12 milhões, o relatório adverte que as condições de segurança operacional no aeroporto encontram-se com os parâmetros recomendados comprometidos em diversos critérios, como faixa de pista e áreas de transição e aproximação.

Com a malha urbana em torno de Congonhas limitando a expansão, a única possibilidade de melhoria é no pátio de aeronaves, que hoje abriga 34 movimentos por hora em 25 posições 12 pontes de embarque e 13 na área remota (por ônibus). Segundo projeções da ANAC, será preciso ampliar a área do pátio de estacionamento em dez posições.

Em Cumbica (Guarulhos), o pátio de aeronaves dará conta da demanda até 2025, mas todo o resto indica que o aeroporto está perto da saturação. As duas pistas atuais permitem 55 movimentos (pousos e decolagens) por hora, o que será suficiente para atender à demanda projetada para 2010 (54 movimentos na hora-pico), mas não para 2015 (66 movimentos na hora-pico).

Os dois terminais de passageiros, habilitados para receber 16,5 milhões de pessoas por ano, estão à beira do limite. A construção de um terceiro terminal (em licitação) aumentará a capacidade para 28,5 milhões de passageiros, o que dará um fôlego temporário, mas a 
demanda ultrapassará de novo a capacidade entre 2010 e 2015 - ano em que se estima a movimentação de 30,7 milhões de passageiros. Ou seja, tudo leva a crer que no médio prazo, Cumbica vai ser um aeroporto tão desconfortável quanto Congonhas atualmente.

Para expandir a infra-estrutura aeroportuária em São Paulo, deve-se considerar que a proximidade e orientação entre as pistas de pouso e decolagem dos atuais aeródromos complicam o gerenciamento do espaço aéreo, afirma a ANAC. A agência lembra que as condições impostas pelo relevo e ocupação de entorno de Guarulhos limitam a futura terceira pista a no máximo 2.100 metros - extensão relativamente curta para um aeroporto de padrão internacional.

Para não levar a infra-estrutura do setor ao caos, o estudo sugere a construção de um terceiro aeroporto em São Paulo - cujos custos iniciais de implantação são estimados em R\$ 500 milhões, desconsiderando o valor de desapropriações e instalações complexas - ou a ampliação de Viracopos (Campinas), mediante reformas, que precisaria de acesso condizente com as necessidades e anseios de seus usuários, capaz de ligar aquele aeroporto à cidade de São Paulo, a fim de viabilizar uma integração rápida e eficiente à capital.

Outras cidades têm situação bastante preocupante. É o caso de Brasília, que se tornou um importante $h u b$ (centro de distribuição de vôos) para o Centro-Oeste e Norte do país. A segunda pista de pouso e decolagem permite o atendimento da demanda até 2010 e, com ajustes para redução do incômodo causado pelo ruído, talvez até além de 2015.

No entanto, o grande problema do aeroporto Juscelino Kubitschek é o terminal de passageiros, com capacidade para 7,4 milhões de pessoas, mas que já atende cerca de 10 milhões, estabelecendo um baixo nível de serviço aos usuários, conforme reconhece a ANAC.

A construção de um segundo satélite (com ponte de embarque e sala de embarque) e o prolongamento do viaduto do terminal devem aumentar a capacidade para 11 milhões de passageiros. A obra está no PAC e é orçada em R \$ 149 milhões, mas dá pouco fôlego: antes de 2010, quando receberá 14,6 milhões de pessoas, o aeroporto já estará novamente saturado.

Embora a agência não faça menções a isso, uma possibilidade é realocar vôos para o Rio de Janeiro, onde os aeroportos do Galeão e Santos Dumont têm relativa folga. 
O estudo indica que os aeroportos de Vitória e de Porto Seguro também já estão com os seus terminais de passageiros saturados. Em 2010, vão juntar-se a eles os aeroportos de Salvador, Curitiba, Fortaleza e Cuiabá.

No relatório, a ANAC critica o desmonte das estruturas de planejamento de longo prazo que viabilizam os investimentos no setor de transporte aéreo e sua infra-estrutura. E conclui, provocando aqueles que não admitem a entrada de empresas na administração dos aeroportos: "As restrições do setor público para realizar investimentos em infra-estrutura podem também ser minimizadas através de uma maior participação do setor privado".

6.4

SITUAÇÃO DOS AEROPORTOS PAULISTAS - PRINCIPAIS HUBS BRASILEIROS

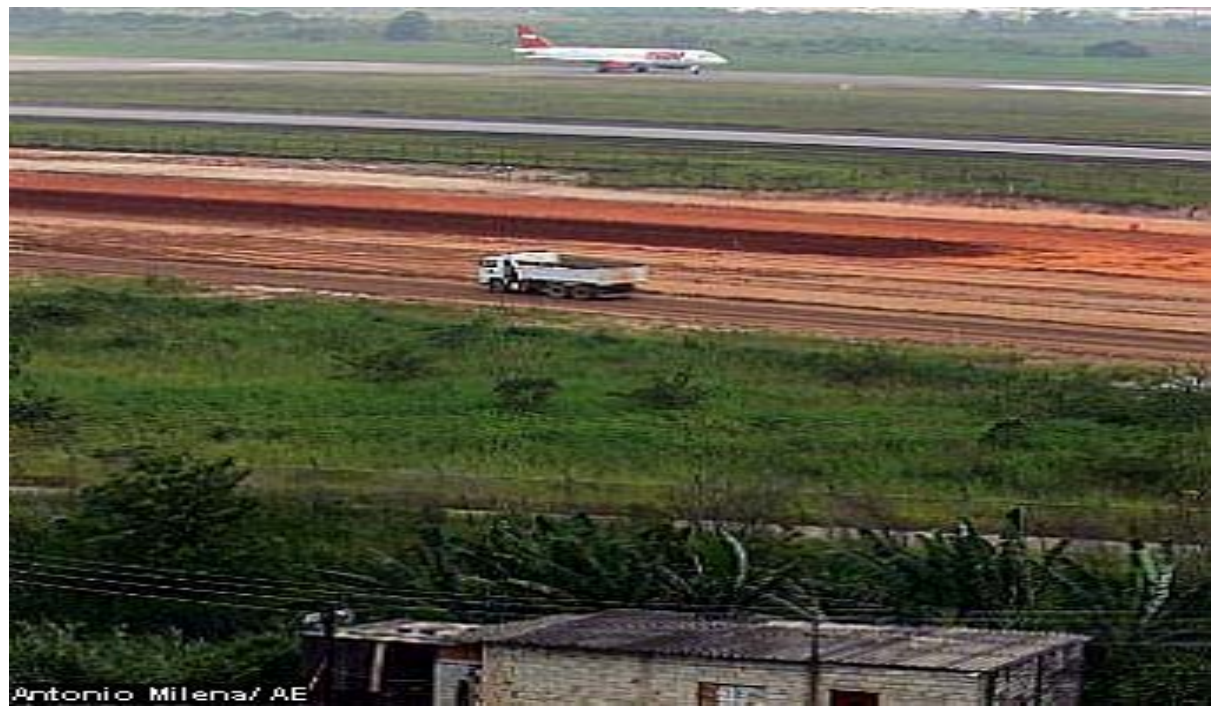

Figura 6.1 - Vista a Partir da Torre de Controle do Aeroporto SBGR

Os aeroportos paulistas mais importantes em termos de modelo hub, estão à beira do colapso, portanto, para absorver demanda até 2015, a capacidade precisa mais que dobrar.

Um estudo inédito do ITA, sobre as realidades e desafios do sistema aeroportuário de São Paulo mostra que, caso não sejam adotadas medidas para ampliar a capacidade operacional, o sistema Guarulhos/Congonhas entrará em colapso. "Existe uma demanda por transporte aéreo em São Paulo que a infra-estrutura instalada não suporta sem a redução do nível de serviço oferecido aos usuários", diz o estudo, assinado pelos professores do ITA Cláudio Jorge Pinto Alves e German Alberto Barragán de Los Rios. 
Tomando por base um levantamento de projeções de crescimento de demanda até 2015, o estudo do ITA mostra que seria preciso ampliar de $220 \%$ a $350 \%$ a capacidade do terminal de passageiros em Congonhas, considerando cenários otimista e pessimista. A capacidade das pistas precisaria aumentar em $50 \%$ a $130 \%$ e o pátio de aeronaves em $410 \%$ a $620 \%$ - o que é impossível diante das limitações físicas do aeroporto. Em Guarulhos, seria preciso ampliar de $40 \%$ a $100 \%$ a capacidade do terminal e do pátio, enquanto as pistas precisariam de um reforço de 20\%. Isso para trabalhar no limite, com 100\% de ocupação ao longo do dia, todos os dias do ano. Logo, em horários de pico, a capacidade já estaria aquém da demanda. "Parte da demanda terá de ser transferida para outro aeroporto ou, simplesmente, terá de optar por outro meio de transporte", diz o estudo do ITA. Considerando que o setor aéreo tem exibido ganhos de eficiência e, nos últimos três anos, cresceu a taxas recordes -3 a 4 vezes superior à expansão do PIB - cenários mais otimistas não podem ser descartados. Para este ano, a previsão é de um crescimento acima de 10\%, ante 12,3\% em 2006 e 19,4\% em 2005.

Os problemas nos aeroportos do estado não afetam apenas paulistas. Como $34 \%$ do movimento de passageiros utiliza Congonhas ou Guarulhos como ponto de partida ou chegada, atrasos ou cancelamentos nos dois aeroportos afetam a malha aérea de todo o país. Apesar de os problemas vividos pelos passageiros do transporte aéreo nos últimos meses terem tornado pública a fragilidade do sistema aeroportuário do país, os investimentos anunciados para os próximos anos estão aquém das previsões de demanda.

O PAC prevê R\$ 3 bilhões para 20 aeroportos até 2010, enquanto a necessidade do setor seria de R 7 bilhões, segundo a própria Infraero. O estado de São Paulo deve receber pouco mais de R\$ 1 bilhão. Entretanto, o PAC não contempla as principais obras apontadas por especialistas para dar conta da demanda nos próximos cinco a dez anos.

São elas: a terceira pista para pousos e decolagens de Guarulhos e a ampliação de Viracopos, Campinas. Esta última só se justificaria com a construção de um trem-bala ligando o aeroporto à capital, projeto ainda em discussão. Há quem defenda a construção, para daqui a dez anos, de um terceiro aeroporto, mais próximo a capital.

O PAC contempla apenas a construção de um terceiro terminal de passageiros em Guarulhos, além de reformas e obras de modernização do sistema de pistas e pátios existentes em Guarulhos e Congonhas. Segundo o superintendente da regional Sudeste da Infraero, Edgar 
Brandão Junior, com essas obras e reformas, a infra-estrutura existente no Estado "estará bem servida" até 2010 .

Para aumentar a capacidade do sistema, o estudo do ITA sugere melhorias operacionais e de infra-estrutura de curto e médio prazo. "A questão da construção ou não de um terceiro aeroporto deve começar a ser estudada já, para que, eventualmente, venha a ser construído dentro de dez anos", diz Pinto Alves. No entanto, argumenta, "se a construção se mostrar inviável, será preciso estimular a transferência de tráfego para aeroportos menores ou regionais".

A adoção de políticas que interfiram na demanda - como transferência de tráfego de um aeroporto para outro e a cobrança de tarifas diferenciadas pelo uso de cada aeroporto - são consideradas pelos estudiosos do ITA como cruciais para redistribuir o tráfego. "A solução não depende apenas de vultosos recursos, mas de uma grande dose de engenhosidade", diz o estudo.

A transferência de tráfego depende de portaria e vem sendo adotada com sucesso pela Infraero e pela ANAC. Foi o que aconteceu no Rio de Janeiro, com a transferência de vôos fora da Ponte Aérea do Santos Dumont para o Aeroporto Internacional Tom Jobim.

A cobrança de tarifas aeroportuárias mais baratas das empresas aéreas para estimular a demanda em aeroportos subutilizados está totalmente descartada pela atual administração da Infraero. "Hoje não se discute política de diferenciação tarifária", declarou a estatal, por meio de sua assessoria.

Guarulhos suporta apenas mais cinco anos de crescimento, portanto, está prevista a principal e mais cara obra da Infraero para São Paulo nos próximos anos - a construção do terceiro terminal de passageiros em Guarulhos - só faz sentido com a construção de um terceiro sistema de pista e pátio, avalia o professor do ITA, Cláudio Jorge Pinto Alves. "Hoje a capacidade das pistas é maior que a dos terminais. Mas o novo terminal, que elevará a capacidade de 18 milhões de passageiros para 30 milhões, ficará ocioso sem uma nova pista." Ele estima que, sem a terceira pista, a vida útil de Guarulhos é de cinco anos. "A partir daí, teremos problemas parecidos com o que temos hoje em Congonhas." 
“Guarulhos precisa de uma terceira pista de qualquer jeito. Caso contrário, terá de começar a operar no sistema de slots (vaga cativa para empresas), o que dificulta a entrada de novas empresas e trava o crescimento do setor", completa o diretor-executivo da Associação Brasileira de Aviação Geral, Adalberto Febeliano.

O brigadeiro Adyr da Silva, engenheiro, presidente da Associação Brasileira de Direito Aeronáutico e Espacial e ex-presidente da Empresa Brasileira de Infra-Estrutura Aeroportuária (Infraero), defende a terceira pista no Aeroporto Internacional Governador André Franco Montoro, em Cumbica, Guarulhos, na Grande São Paulo, como alternativa para resolver o problema aeroportuário até, no mínimo, o ano de 2030. Ele é contrário à construção de um terceiro aeroporto na região metropolitana.

"Não cabe um novo aeroporto em São Paulo antes que se esgotem outros investimentos nos já existentes, com custos muito mais baixos. Com cerca de $\mathrm{R} \$ 700$ milhões, é possível construir a terceira pista em Guarulhos e resolver o problema da crise aeroportuária de forma mais econômica, rápida, equilibrada e competente. Incluindo os novos terminais, conseguiremos viabilizar o transporte de até 56 milhões de passageiros ao ano só em Cumbica, explica Adyr.

De acordo com estudos apresentados pelo brigadeiro no Fórum de Desenvolvimento Sustentável organizado pela AGENDE - órgão não-governamental, que reúne poder público, iniciativa privada e sociedade civil -, as duas pistas já existentes no Aeroporto de Guarulhos podem operar juntas com a terceira. Para Adyr, as decisões que têm sido tomadas para solucionar a crise estão baseadas nas conseqüências e não nas causas. "A crise aérea não surgiu agora, ela já tem de sete a nove anos, com raízes muito profundas. Os paliativos são bons, mas o problema é estrutural e não se resolve tão fácil.

Conforme pesquisa disponível no BDISEG, a circulação registrada em outubro no aeroporto em Cumbica, foi maior que 1,726 milhões, que é um recorde histórico para um único mês. Isso equivale a uma média anual de 20,720 milhões de passageiros - a capacidade máxima que a estrutura atual comporta 21 milhões ao ano.

O governo, porém, “jogou a toalha” em relação à terceira pista de Guarulhos, segundo declarou recentemente o ex. presidente da Infraero, José Carlos Pereira. A terceira pista faz parte do projeto original do aeroporto. Para tirá-la do papel, seria preciso enfrentar questões 
ambientais e sociais. O entorno do aeroporto hoje é uma Área de Proteção Ambiental. E o local onde seria a pista virou uma favela com 5,3 mil barracos. "A cada dia, fica mais caro e mais difícil iniciar as obras", diz Febeliano.

Hoje, ocioso, Viracopos tem planos ambiciosos de expansão. Enquanto descarta, por ora, a remoção de uma favela na área de Guarulhos, adiando indefinidamente a construção de um terceiro sistema de pista e pátio, a infraero já iniciou um processo de desapropriação de terras no entorno do aeroporto de Viracopos, em Campinas.

Segundo o superintendente da regional Sudeste da infraero, Edgar Brandão Junior, o orçamento de 2007 da estatal prevê R\$ 33 milhões para desapropriações em Campinas. "São grandes propriedades, um haras, algumas áreas rurais", explica Brandão. No local, será construído um segundo sistema de terminal e pista, obra que não deve sair do papel antes de 2010. A desapropriação inclui uma área onde, num futuro ainda mais distante, poderá ser construída uma terceira pista. "É uma reserva de área, para dar tranqüilidade no futuro."

O custo total da construção do segundo sistema de terminal e pistas ainda não está definido. $\mathrm{O}$ projeto prevê a incorporação, nas dependências do terminal, de uma linha de trem expresso, que deve ligar Viracopos ao centro de São Paulo. O trem, a ser construído pela iniciativa privada, é tido como fundamental para que Viracopos venha a absorver a demanda excedente de Guarulhos e Congonhas - e justificar a ampliação, já que hoje o aeroporto opera com ociosidade.

No entanto, o trem de Viracopos está bem menos adiantado que o de Guarulhos, previsto para entrar em operação em 2009. O Expresso Aeroporto já despertou interesse de mais de 100 empresas, que têm até abril para entregar propostas.

Segundo o brigadeiro Adyr da Silva, o governo precisa investir entre R $\$ 6$ bilhões e R\$10 bilhões para fazer uma atualização tecnológica dos equipamentos de comunicação, navegabilidade e tráfego aéreo. A estimativa também leva em conta reformas de pistas com mais de meio século de idade, construídas em parceria com os americanos durante a Segunda Guerra Mundial, como nos aeroportos de Natal, Fortaleza, Recife e Belém, Ele recomenda tais investimentos em um período de dois a três anos, "mas tudo depende da velocidade que se quiser dar a essa atualização tecnológica". O brigadeiro Adyr da Silva defende também a 
criação de áreas de segurança, entre 60 e 200 metros, em aeroportos com pistas curtas, como Congonhas. Nessas áreas podem ser implantados "tapetes de contenção", com material de forte atrito, para segurar aviões em pouso que não consigam frear até o fim das pistas.

Segundo a IFALPA, materiais como concreto triturado e areia grossa podem ser usados nos tapetes de contenção - tradução livre para os arrestor beds, adotados em aeroportos como JFK, em Nova York, e London City, em Londres. Adyr da Silva lembra que, em 1998, o Brasil promoveu e sediou uma conferência internacional para planejar a introdução de satélites para uso aeronáutico - o sistema CNS/ATM. Esse sistema deve começar a ser implantado até 2010 e fará o controle de tráfego via satélite, complementando o trabalho dos radares. O efeito sobre a segurança é relevante: acabarão os chamados "pontos cegos" na Amazônia e sobre o Oceano Atlântico. "Infelizmente, estamos a três anos do prazo planejado e quase nada foi feito."

Hoje professor da UnB, o brigadeiro reformado argumenta ainda que é necessário readequar pistas sobrecarregadas por mais de meio século de uso. As pistas das capitais do Norte e Nordeste, foram construída na década de 1940, em plena Segunda Guerra Mundial. Pouquíssimas têm asfalto poroso, que aumenta a aderência dos pneus ao solo, como no Santos Dumont, no Rio.

6.5 PRINCIPAIS INFRA-ESTRUTURAS DE UM AEROPORTO

\subsubsection{Pistas e Pátios de Aeroportos}

Neste item serão abordados dois assuntos de extrema importância para operações em sistema hub and spoke: (a) a sinalização aeroportuária e (b) o pátio de estacionamento para aeronaves incluindo as pontes de embarque. Um dos aspectos mais importantes em um aeroporto é a sua sinalização, tanto em termos de comunicação visual, como em termos de orientação. As pistas, utilizadas por pilotos e tripulações das mais diversas origens, têm uma sinalização padronizada. O balizamento noturno e as marcas ou sinalização diurnas são essenciais para o uso eficiente e seguro do aeroporto. Conforme preconizava a FAA (AC 150/5340), as marcas regulamentares (marcação mínima) dependem da classificação da pista: 
- Pista com Operações Visuais

- Pista com Operação Instrumento

- Pista com Operação Instrumento de Precisão

Curiosamente verifica-se que quanto mais instrumentada é a pista, maiores são os requisitos para sua inalização. Isto se deve ao fato de, para esses casos, instrumentada de precisão, ser permitida, operação sob condições de fraca visibilidade.

É bom frisar que uma pista é instrumentada com precisão, quando os equipamentos fornecem à aeronave informação de posicionamento espacial (ILS ou radar). Uma pista instrumentada simples é dotada de VOR ou NDB. Já o pátio de estacionamento para aeronaves depende das atividades previstas de serem executadas durante a parada da aeronave. Serviços de reabastecimento de combustível, embarque e desembarque de passageiros, bagagens e carga, serviços de manutenção da aeronave são algumas das atividades comuns desenvolvidas nessa área. Cada aeronave, no pátio, deve ocupar uma posição de estacionamento, um boxe (gate position ou stand), normalmente, bem identificado através de: sinalização de parada ("T" de parada), sinalização do rolamento (linha amarela contínua da trajetória do trem de bequilha da aeronave) e, algumas vezes, de equipamentos de auxílio à parada (visuais, eletrônicos ou de contacto). As pontes de embarque constituem-se no meio mais moderno de transferência de passageiros entre o terminal e a aeronave. Podem ser fixas ou móveis: cada tipo apresenta vantagens e desvantagens para a operação aeroportuária. A Infraero têm denominado de fingers as pontes de embarque em alguns dos seus aeroportos.

Conforme a seguir apresentaremos uma lista das principais infra-estruturas que necessariamente compõe um aeroporto. Entretanto, para operacionalizar esta estrutura com atividades de um sistema hub é diferente, considerando o grande fluxo de pessoas, aeronaves, veículos e equipamentos que circulam em busca do melhor atendimento, rapidez, segurança e com tempo mínimo de conexão. Objetivo principal da conexão no hub. Portanto, é necessário um ótimo funcionamento.

- Pistas de pouso e decolagem

- Controle de tráfego aéreo

- Grandes aeroportos de uso Civil (passageiros e/ou carga)

o Terminais de Passageiros 
o Trânsito e Transportes (rodoviários, ferroviários)

o Manutenção dos aviões

- Terminal de Carga e correio aéreo

o Empresas Aéreas

o Serviços de Combustíveis

o Serviços Auxiliares Controle Espaço Aéreo

- Aviação geral

- Manutenção

- Segurança - (Security e Safety)

- Poluição - controle de meio ambiente

- Aeroportos militares (Bases aéreas)

- Aeroportos marítimos

- Serviços de Comissária

- Serviços de Restaurantes

- Concessionários

- Instituições governamentais

\subsubsection{Pistas de Pouso e Decolagem}

Como foi dito anteriormente, um aeroporto que tem suas operações baseadas no sistema hub, deve ser preparado para permitir o pouso e decolagens de aeronaves simultaneamente. Para tal, uma parte indispensável num aeroporto são as pistas de pouso e decolagem, que precisam ser suficientemente compridas e largas para permitirem operações de pouso e decolagem das maiores aeronaves usando o aeroporto. Além disso, as pistas precisam ser planas, sem ou com as mínimas inclinações possíveis, dotadas de todos os sistemas de auxílio à navegação. 


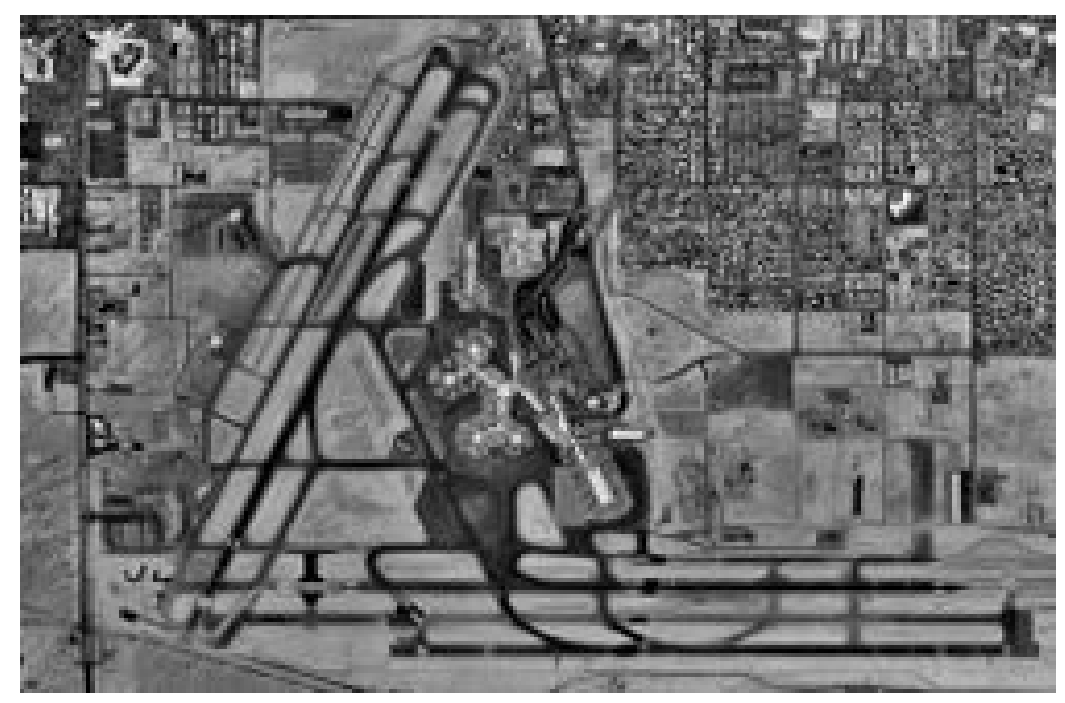

Figura 6.2 - Vista de Satélite do Aeroporto

Em aeroportos movimentados, as pistas são feitas geralmente de asfalto ou concreto. Porém, campos de aterrisagem de pequeno porte em pequenas cidades e áreas isoladas, muitas vezes possuem suas pistas feitas com terra, grama ou turfa.

Para o auxílio da movimentação de aeronaves em terra (após um pouso ou antes de uma decolagem, por exemplo), existem as taxiways, pistas de auxílio que agilizam o tráfego de aeronaves no solo.

As cabeceiras das pistas dos aeroportos precisam ser livres de quaisquer obstáculos que possam atrapalhar ou pôr em risco a operação de uma dada aeronave. A reta de aproximação final de aeronaves, por isto, precisa ser livre de obstáculos.

\subsubsection{Auxílios Visuais Diurnos (Padrão Anexo XIV da ICAO)}

As pistas pavimentadas com operação visual devem ser dotadas, no mínimo, de:

\section{a) Marcas de Eixo de Pista}

São faixas pintadas (de $30 \mathrm{~m}$ de comprimento) intervaladamente (a cada $20 \mathrm{~m}$ ) pintadas sobre o eixo da pista. A largura mínima das mesmas varia: $30 \mathrm{~cm}$ nas pistas de operação visual e $45 \mathrm{~cm}$ e $90 \mathrm{~cm}$ para as pistas instrumentadas. Ajustes nos comprimentos ou espaçamentos entre as faixas (função do comprimento da pista) devem ser realizados no ponto médio da pista. 


\section{b) Marcas de Numeração de Cabeceira}

Pistas são identificadas por números em suas cabeceiras. Em cada cabeceira, na posição de largada para a corrida de decolagem, é marcada a direção da pista em relação ao Norte Magnético em dezenas de graus no sentido horário. Em função da variação da declinação magnética, direções como 135 graus podem receber a numeração 13 ou 14 (correspondente aos 130 ou 140 graus). Assim sendo em uma mesma pista (cabeceiras em oposição) teremos uma numeração sempre com diferenças de 180 graus, isto é, de 18. Pista 01-19, 0220, 03-21 e assim sucessivamente.

O desenho dos algarismos é padronizado com $9 \mathrm{~m}$ de altura, não ultrapassando a $4 \mathrm{~m}$ de largura. Além do número, a designação de cabeceira pode receber uma letra (L, C ou R) em casos de pistas paralelas: L para esquerda, C para a pista central e R para a pista da direita.

\section{c) Marcas de Espera}

O cruzamento de fluxos (interceptação de pistas) deve ser marcado por uma linha contínua (ou duas) do lado da entrada na pista de maior precedência e uma barra (ou duas) tracejada (paralela a linha contínua) do lado da saída da pista de maior precedência. Isso representa a liberdade de sair da pista principal, permitindo, o mais rápido possível, sua liberação para novos usos. Assim como o traço contínuo representa um sinal de parada, obrigatório para quem adentra a pista principal, a ser vencido pela aeronave quando for autorizada. A distância que essas linhas devem estar, sinalizando o ponto em que a aeronave deve parar, depende do emprego ou não de equipamentos de auxílio a rádio-navegação que exigem áreas livres para não prejudicar seu funcionamento. Para as pistas instrumentadas, além das três anteriores, no mínimo, devem ser pintadas também as:

\section{d) Marcas de Cabeceira}

São faixas de $30 \mathrm{~m}$ por $1,8 \mathrm{~m}$ simetricamente dispostas em relação ao eixo. $\mathrm{O}$ espaçamento é de 1,8 m entre as faixas e de 3,6 m entre as faixas centrais. Pistas maiores ou menores de $45 \mathrm{~m}$ podem ter alterados proporcionalmente as larguras e as separações entre as faixas. Essas são colocadas a $6 \mathrm{~m}$ do limite da 
cabeceira da pista. $\mathrm{O}$ número de faixas é variável: 4 , nas pistas de $18 \mathrm{~m}, 8$ nas de $30 \mathrm{~m}, 12$ nas de $45 \mathrm{~m}$ e 16 faixas nas pistas com largura de $60 \mathrm{~m}$.

\section{e) Marcas de Distância Fixa}

Compõem-se de dois pares de faixas, um par para cada cabeceira, sendo cada faixa com 4 a $10 \mathrm{~m}$ de largura e 30 a $60 \mathrm{~m}$ de comprimento, separadas de 6 a 22,5 m simetricamente postadas em relação ao eixo da pista. Cada par é pintado a $150 \mathrm{~m}$ (pistas de comprimento inferior a $800 \mathrm{~m}$ ), $250 \mathrm{~m}$ (pistas entre 800 e $1200 \mathrm{~m}$ ), $300 \mathrm{~m}$ (pistas entre 1200 e $2400 \mathrm{~m}$ ) e $400 \mathrm{~m}$ (pistas superiores a $2400 \mathrm{~m}$ ). Servem para o piloto como uma referência de que distância se está em relação às cabeceiras da mesma. Para as de precisão incluem-se ainda:

\section{f) Marcas de Zona de Toque}

Para facilitar a localização do piloto na pista, pintam-se uma série de faixas paralelas por toda a extensão da pista considerada para se proceder ao toque da aeronave com o solo. São faixas de $22,5 \mathrm{~m}$ por $1,8 \mathrm{~m}$ de largura. São dois conjuntos paralelos de três faixas (entre essas a separação é de 1,5 m) separados de 21,6 m e marcados a $150 \mathrm{~m}$ da cabeceira. A cada $150 \mathrm{~m}$ de distância a mais, pintam-se novos conjuntos com as seis faixas, depois com quatro, outro com quatro, e mais um com dois e finalmente, a $900 \mathrm{~m} \mathrm{da}$ cabeceira, um último com duas faixas. A distância mantida entre as faixas mais próximas do centro da pista ficam a 21,6 m, em todos os conjuntos. A pista normalmente apresenta essa sinalização para ambas as cabeceiras.

\section{g) Marcas de Bordo de Pista}

Para distinguir a pista do terreno a sua volta se pinta uma faixa contínua no bordo da pista com espessura de $90 \mathrm{~cm}$. Todas as marcas em pista de pouso devem ser em branco. Para melhor discriminação de fundo, as marcas podem ser molduradas em negro. As marcas em pista de táxi e pátios são pintadas em amarelo. As especificações de material e procedimentos de pintura estão contidas na AC 150/5370 (Standards for Specifying Construction on Airports). 


\subsection{4}

\section{Auxílios Visuais Noturnos}

O Anexo XIV da ICAO descreve diversos sistemas de balizamento noturno. O objetivo é de propiciar aos pilotos efetuarem a aproximação, o pouso, a circulação e a decolagem, à noite ou em condições meteorológicas desfavoráveis, sob nível adequado de visibilidade. Para a pista de pouso:

- Luzes de obstáculos

- Sistema de Luzes de Aproximação

- Luzes Laterais de Pista (branca ou ambar)

- Luzes de Cabeceira de Pista (verdes)

- Luzes de Fim de Pista (vermelhas o REIL)

- Luzes de Eixo de Pista (branca ou ambar)

- Luzes de Zona de Toque

- Para a pista de táxi:

- Luzes Laterais de Pista (azuis)

- Luzes de Eixo de Pista (verdes)

- Luzes de Saída de Pista

- Luzes de Parada (vermelho)

O VASIS e suas derivações, como o PAPI, constituem-se em auxílios com uso de luzes para operação (diurna ou noturna), que permitem ao piloto se localizar em relação a uma trajetória indicada de descida (se acima, se abaixo ou sobre a trajetória de aproximação especificada pelo equipamento). A instalação dos equipamentos ou luzes depende da categoria do aeroporto, tendo-se coerência com a implantação do balizamento diurno. As luzes (tipo de eixo de pista ou de zona de toque) cuja instalação represente altos custos, com corte e incrustação em superfícies já pavimentadas, tem seu emprego recomendado apenas em aeroportos de movimento intenso e em cujas pistas se operem em IFR Cat 2 ou 3.

\subsubsection{Pátio de Estacionamento de Aeronaves}

O projeto do pátio de estacionamento de aeronaves depende: 
Da configuração do terminal de passageiros e das separações para segurança e proteção dos passageiros e funcionários contra: os jatos de exaustão da aeronave (jet blast), o calor e o ruído produzido pela aeronave etc. Da posição de parada em relação à edificação do terminal (paralela, inclinada e frontal, com ou sem auxílio de tratoragem). Das características físicas e operacionais da aeronave (pontos de abastecimento, posição de porta etc.). Do tipo de prestação dos serviços de apoio no solo (fixo ou móvel). Nas operações envolvendo aeroporto hub, a concentração de aeronaves e veículos circulando nos pátios sofre um aumento significativo, em função disso, deverão ser observados, principalmente quando do embarque e desembarque de passageiors de conexão em posições recuadas e remotas.

\subsubsection{Pontes de Embarque}

Também conhecidas como "passarelas" foram inicialmente introduzidas nos aeroportos norteamericanos no início da década de sessenta para atendimento às aeronaves de grande capacidade (DC-8 e Boeing 707). Na Europa surgiram inicialmente em Orly (França) em 1968. No Brasil, os então novos aeroportos de Manaus (1975) e do Rio de Janeiro (1977) foram os pioneiros no uso das mesmas. Trata-se de um equipamento de auxílio ao procedimento de embarque e desembarque dos passageiros, protegendo-os do ambiente (trânsito) e das intempéries climáticas. Serve como um túnel de proteção ligando o interior da aeronave com o interior da edificação.

Antes de sua implantação os passageiros necessariamente saiam ao ar livre no deslocamento entre o terminal e o interior da aeronave, a pé ou com uso de veículos motorizados. Existem dois tipos principais de passarelas:

a) Fixas ou com Pedestal que, a princípio, a aeronave vem até o seu contacto;

b) Móveis que, a princípio, o equipamento se desloca até a proximidade da aeronave estacionada.

Outros tipos observados são: Semi-fixas Telescópicas, Móvel Radial e Fixa sobre Asas.

Passarelas Fixas: constituem-se de anti-câmara ou quadro, galerias, pedestal ou pórtico elevadiço e cabine ou cabeça de acoplagem. As galerias principais podem ter de 10 a $30 \mathrm{~m}$ e as secundárias de 6 a 10 m. A inclinação máxima é de 15\%. Largura mínima no interior de 
1,40 m. A cabine de acoplagem pode variar a altura do piso em até 3,40 m. A velocidade vertical da cabeça é de $0,75 \mathrm{~m} / \mathrm{s}$.

Constituem-se de: rotunda, galeria telescópica, trens de rolamento e cabine ou cabeça de acoplagem. A velocidade da parte telescópica é de 0,1 a $0,2 \mathrm{~m} / \mathrm{s}$. O piso da passarela deve ser anti-derrapante e permitir que os incapacitados (cadeiras de rodas) trafeguem entre as junções das galerias. A inclinação recomendada é de $10 \%$ (tolerada até $12 \%$ ). Todos os tipos de passarelas devem possuir um sistema automático de nivelamento entre o piso da aeronave e o piso da passarela de tal forma que durante o carregamento ou descarregamento da aeronave, o abaixamento ou levantamento da mesma, mantenha a continuidade do fluxo sem desnivelamentos.

Além de vários associados à segurança operacional (alarme de incêndio, vazamento de fluidos etc.) podem ser associados vários serviços de rampa: cabeamento de energia elétrica $400 \mathrm{~Hz}$, tubulações de ar comprimido e de ar climatizado, fornecimento de água potável e abastecimento de combustível. Esses dois últimos mais raros de se observarem.

As ligações com o terminal desde uma passarela podem ser feitas: diretamente ou através de uma pré-passarela (galeria). Nesse segundo caso normalmente as vias de serviço circulam sob a estrutura da galeria. Modernamente é recomendada a separação entre os fluxos de embarque e desembarque, possibilitando-se assim o desemboque de corredores diversos a uma mesma passarela.

Existem diferentes tipos de equipamentos que servem de auxílio ao piloto para o estacionamento nos terminais: sistemas visuais (ópticos), sistemas eletrônicos (luminosos ou magnéticos) e sistemas de contacto (de barras robotizadas).

O STBA, organismo frances, considera distâncias menores de $30 \mathrm{~m}$ como negligenciáveis, caminhadas até 100 m aceitáveis. Daí aos 300 m o nível de conforto do percurso é mediano e, além disso, é ruim. Portanto percursos a pé além dos $100 \mathrm{~m}$ deveriam ser processados através de veículos (vans ou ônibus). 
Por conceito do TPS, entende-se como a disposição física de facilidades do terminal em função do tipo de operação do aeroporto. Os conceitos existentes são classificados em relação a diversos fatores.

O TPS é a parte do complexo aeroportuário que o passageiro tem maior contato direto. A maioria das percepções em termos de conforto, eficiência, segurança dos passageiros com relação ao hub depende do terminal de passageiros. Por isso o edifício do TPS ganhou uma grande importância, tanto em termos de custos, quanto em termos de pesquisas visando facilitar o processo de interface entre os transportes terrestres e o transporte aéreo. Nos primórdios da aviação, até o advento das aeronaves wide-body a maior preocupação residia sobre o sistema de pistas e pátios, devido às constantes mudanças tecnológicas no campo aeronáutico.

O TPS pode afetar o desenvolvimento nos atendimentos dos passageiros de conexão e logicamente o hub, em função das facilidades necessárias, com órgãos públicos.

O terminal de passageiros consiste portanto numa edificação onde se efetua uma série de processos associados à transferência de passageiros intermodais. Abriga prestadores de serviços de diferentes interesses que propiciam as condições de conforto e segurança desejadas pelos usuários do transporte aéreo, incluindo a capacidade operacional no atendimento de grande quantidade de passageiros, em especial, os passageiros em conexão no hub, considerando o mínimo tempo de conexão, que deve ocorrer de 15 a 25 minutos de acordo com o FAA.

Os TPS são divididos em centralizados e não centralizados. Terminais centralizados são aqueles em que o processamento de passageiros e de bagagens é realizado em um único edifício, enquanto os terminais não centralizados são aqueles em que os processamentos de passageiros e de bagagens são efetuados em vários edifícios ou em diversos módulos de um mesmo edifício. É interessante ressaltar (Horonjeff, 1994) que os terminais centralizados apresentam ganhos em economia de escala, isto é, um mesmo componente pode ser utilizado por vários vôos. 
Neste caso são considerados os formatos em planta do terminal, tendo cada características peculiares de operação. Entre os principais conceitos, destacam-se:

\subsubsection{Linear}

O terminal linear é aquele constituído de áreas comuns tanto de processamento de passageiros quanto de espera, tendo saídas diretas para o pátio de aeronaves. Para operações de embarque e desembarque de passageiros de conexão, no caso de hub, depedendo da distância das aeronaves até a sala de pré-embarque, pode haver atraso para o deslocamento do passageiro de conexão. O terminal linear apresenta pequenas distâncias a serem percorridas pelos passageiros, desde o meio fio até o portão de embarque a ser utilizado. Este conceito é o utilizado na maioria dos aeroportos brasileiros devido ao baixo movimento nesses aeroportos e a limitação financeira existente para sua construção. O layout de um terminal linear deve considerar a possível expansão do mesmo para outros conceitos. Nos casos de maior movimento os terminais lineares tornam-se descentralizados, isto é, passam a contar com diversos módulos de embarque - desembarque distinto. Exemplos: Dallas Fort Worth International, Rio de Janeiro/ Galeão e São Paulo/ Congonhas.

\section{Pier ou Finger}

O edifício terminal em pier é um conceito centralizado muito utilizado em aeroportos que precisam dispor de uma fronteira aeronave - edificação mais extensa. Neste conceito a interface entre o terminal e as aeronaves se dá em corredores originados em um prédio central. As aeronaves são posicionadas ao longo do eixo do píer paralelamente ou nose-in, sendo a segunda posição a mais freqüente. Nos corredores podem-se encontrar facilidades (lanchonetes, livrarias, lojas, etc.), salas de pré-embarque e, nas suas raízes, atividades de filtragem como a vistoria anti-seqüestro e a vistoria de passaportes (em vôos internacionais), portanto, estas facilidades são fundamentais para passageiros de conexão no hub. Em aeroportos de grande porte são utilizados tapetes rolantes para minimizar a distância percorrida pelos passageiros. Exemplos: São Paulo/ Guarulhos, New York La Guardia, Paris/ Orly e Frankfurt. 


\section{Satélite}

O terminal em satélite surgiu de uma evolução do conceito píer. No caso do satélite, as aeronaves são estacionadas ao redor de uma edificação isolada do edifício principal do aeroporto. Este edifício é tal que dentro dele possa haver componentes de espera e/ou de processamento. Em suma, as aeronaves transferem seus passageiros de ou para um edifício que não o principal. Os diversos tipos de transporte dos passageiros entre o satélite e o edifício principal criam as variações deste conceito. Estas ligações podem ser utilizadas para embarque de passageiros de conexão visto as aeronaves são estacionadas mais próximas uma das outras, portanto, ideal para operações de $h u b$.

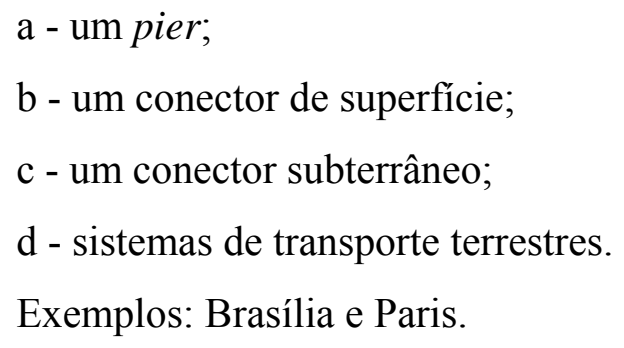

\section{Transporter}

O conceito de transporter baseia-se no estacionamento das aeronaves em posições distantes ao edifício terminal e o acesso dos passageiros às aeronaves se dá através de ônibus ou salas de embarque móveis (mobile lounges). Este conceito afasta os inconvenientes da operação das aeronaves próxima ao edifício principal (poluição sonora), porém traz a desvantagem de um transporte intermediário onerando assim a operacionalidade do processo. Dispensa a sala de pré-embraque na edificação, o próprio ônibus cumpre essa tarefa. Exemplos: Washington/ Dulles e Montreal/ Mirabel.

\section{Híbrido}

O conceito híbrido é a composição de dois ou mais conceitos ponderando para isso as vantagens e as desvantagens de cada um em função das mudanças do perfil operacional do aeroporto. Exemplos: Paris (linear e transporter), Atlanta (pier e transporter). 


\subsubsection{Conceito, Vantagens e Desvantagens em Relação ao Hub}

Tabela 6.1 - Vantagens e Desvantagens dos Conceitos de TPS

\begin{tabular}{|l|c|c|}
\hline \multicolumn{1}{|c|}{ Conceito } & Vantagens & Desvantagens \\
\hline Linear & $\begin{array}{l}\text { acesso direto do meio fio } \\
\text { ao portões de embarque }\end{array}$ & $\begin{array}{l}\text { não permite a utilização comum } \\
\text { de recursos pode gerar altos }\end{array}$ \\
\hline
\end{tabular}

\begin{tabular}{|c|c|c|}
\hline & $\begin{array}{l}\text { - flexibilidade para } \\
\text { expansões }\end{array}$ & $\begin{array}{l}\text { custos operacionais se expandido } \\
\text { para edifícios diferentes }\end{array}$ \\
\hline $\begin{array}{l}\text { Pier ou } \\
\text { "Finger" }\end{array}$ & 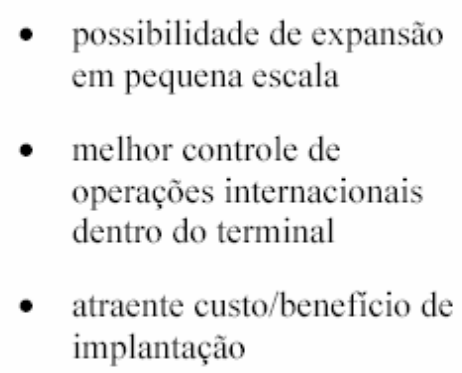 & $\begin{array}{l}\text { maiores distâncias percorridas } \\
\text { falta de relação direta entre o } \\
\text { meio fio e os portões de embarque }\end{array}$ \\
\hline Satélite & $\begin{array}{l}\text { - facilidade de manobra das } \\
\text { aeronaves em torno do } \\
\text { satélite } \\
\text { - possibilidade de } \\
\text { concentração de operações } \\
\text { internacionais } \\
\text { - facilita operação de } \\
\text { conexões }\end{array}$ & $\begin{array}{l}\text { alto custo de implantação falta de } \\
\text { flexibilidade para expansões } \\
\text { distância percorridas elevadas }\end{array}$ \\
\hline "Transporter" & 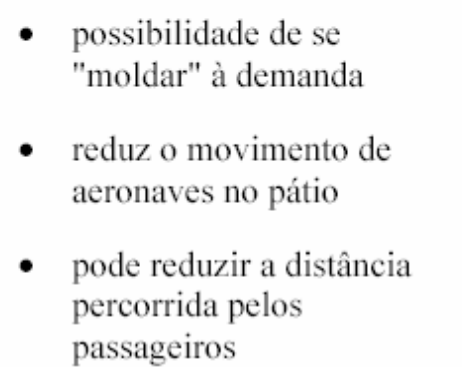 & $\begin{array}{l}\text { os "transporters" elevam o tempo } \\
\text { dos processos de embarque e } \\
\text { desembarque de passageiros pode } \\
\text { gerar congestionamento de } \\
\text { veículos no pátio }\end{array}$ \\
\hline
\end{tabular}




\subsection{8}

Nível de Serviço e o $\mathrm{Hub}$

A capacidade de qualquer instalação ou serviço está sempre associada a um nível de serviço. Por exemplo: espaço disponível por pessoa, tempo médio de atendimento etc. Nível de serviço percebido é uma quantificação do nível de serviço prestado através da percepção do cliente, no caso aeroportuário, do passageiro e das equipes que trabalham no aeroporto. Este serviço recebe uma maior exigência quando se trata de hub, em função do tempo e capacidade operacinal disponível em relação à demanda.

Para componentes de processamento, o nível de serviço pode ser avaliado principalmente através do tempo de atendimento e espera e do espaço disponível para cada passageiro.

No caso de componentes de espera o nível de serviço pode ser medido através do espaço disponível para cada passageiro ou visitante, da disponibilidade de assentos, do conforto do ambiente, da facilidade de acesso às demais áreas de interesse e da disponibilidade de concessões comerciais entre outros. Dentre estes fatores o mais simples de se mensurar, logo o mais utilizado, é o espaço disponível para cada passageiro ou visitante.

Já para os componentes de circulação o nível de serviço pode ser contabilizado através da distância percorrida, da informação visual disponível, do espaço disponível, das possíveis mudanças de nível (circulação vertical), etc.

Como o espaço disponível é o fator mais utilizado na prática, apresentaremos uma tabela de referência, para aeroportos brasileiros, onde se encontram listados os índices de dimensionamento segundo três níveis de serviço diferentes: A - Muito bom, B - Bom e C Regular; para três tipos de aeroportos: o internacional, o doméstico e o regional. Dados e percepções obtidos em seis aeroportos serviram de referência para a validação dos índices propostos (Medeiros 2004), (vide tabelas a seguir). As tabelas em questão apresentam o dimensionamento ideal de algumas facilidades para atendimento no modelo hub and spoke. 
Tabela 6.2 - Saguão de Embarque (a)

\begin{tabular}{|c|c|c|c|}
\hline \multicolumn{4}{|c|}{ SAGŨ̃O DE EMBARQUE } \\
\hline \multirow{3}{*}{$\begin{array}{l}\text { Nível de } \\
\text { serviço }\end{array}$} & \multicolumn{3}{|c|}{ Índices de dimensionamento (m²/usuário) } \\
\hline & \multicolumn{3}{|c|}{ Tipo de aeroporto } \\
\hline & Internacional & Doméstico & Regional \\
\hline A - Alto & 2,50 & 2,20 & 1,80 \\
\hline B - Bom & 2,00 & 1,80 & 1,50 \\
\hline C-Regular & 1,60 & 1,40 & 1,20 \\
\hline
\end{tabular}

Tabela 6.3 - Saguão de Embarque (b)

\begin{tabular}{|l|c|c|}
\hline \multicolumn{2}{|c|}{ SAGUÃO DE EMBARQUE } \\
\hline \multirow{2}{*}{$\begin{array}{c}\text { Nível de } \\
\text { serviço }\end{array}$} & Quantidade de assentos (\% do no de usuários) \\
\cline { 2 - 4 } & Se tiver sala de pré-embarque & Se não tiver sala de pré-embarque \\
\hline A - Alto & 25 & 70 \\
\hline B - Bom & 15 & 60 \\
\hline C - Regular & 10 & 50 \\
\hline
\end{tabular}

Tabela 6.4 - Sala de Pré-Embarque (a)

\begin{tabular}{|c|c|c|c|}
\hline \multicolumn{4}{|c|}{ SALA DE PRÉ-EMBARQUE } \\
\hline \multirow{3}{*}{$\begin{array}{l}\text { Nível de } \\
\text { serviço }\end{array}$} & \multicolumn{3}{|c|}{ Largura do corredor de acesso ao portão de embarque (m) } \\
\hline & \multicolumn{3}{|c|}{ Tipo de aeroporto } \\
\hline & Internacional & Doméstico & Regional \\
\hline A - Alto & 3,00 & 2,50 & 2,00 \\
\hline $\mathrm{B}-\mathrm{Bom}$ & 2,50 & 2,00 & 1,50 \\
\hline $\mathrm{C}-$ Regular & 2,00 & 1,50 & 1,00 \\
\hline
\end{tabular}


Tabela 6.5 - Sala de Pré-Embarque (b)

\begin{tabular}{|c|c|}
\hline Nível de servico & $\begin{array}{l}\text { Quantidade de assentos } \\
\text { (\% do } \mathrm{n}^{\circ} \text { de passageiros) }\end{array}$ \\
\hline$A-$ Alto & 80 \\
\hline $\mathrm{B}-\mathrm{Bom}$ & 70 \\
\hline C-Regular & 60 \\
\hline
\end{tabular}

Tabela 6.6 - Triagem e Despacho de Bagagens

ÁREA PARA TRIAGEM E DESPACHO DE BAGAGENS

Índices de dimensionamento $\left(\mathrm{m}^{2} / \mathrm{vôo}\right)$

Tipo de aeroporto

\begin{tabular}{|c|c|c|}
\hline Internacional & Doméstico & Regional \\
\hline 40,00 & 40,00 & 20,00 \\
\hline
\end{tabular}

Tabela 6.7 - Vistoria de Segurança

\begin{tabular}{|c|c|c|}
\hline \multicolumn{3}{|c|}{ AREA DE VISTORIA DE SEGURANGA } \\
\hline \multicolumn{3}{|c|}{ Tipo de aeroporto } \\
\hline Internacional & Doméstico & Regional \\
\hline $20,00 \mathrm{~m}^{2} / \mathrm{módul}$ & $16,00 \mathrm{~m}^{2} / \mathrm{módu}^{\prime}$ & $13,50 \mathrm{~m}^{2} / \mathrm{módulo}$ \\
\hline \multicolumn{2}{|c|}{ Tempo de atendimento por pax (seg) } & Processamento $(p a x / h)$ \\
\hline \multicolumn{2}{|c|}{20} & 180 \\
\hline
\end{tabular}


Tabela 6.8 - Vistoria de Passaporte

\begin{tabular}{|l|c|}
\hline \multicolumn{1}{|c|}{ ÁREA DE VISTORIA DE PASSAPORTES } \\
\hline \multicolumn{2}{|r|}{ Aeroporto Internacional } \\
\hline Nível de serviço & Índice de dimensionamento $\left(\mathbf{m}^{2} /\right.$ pax $)$ \\
\hline A - Alto & 1,20 \\
\hline B - Bom & 1,00 \\
\hline C - Regular & 0,80 \\
\hline
\end{tabular}

Tabela 6.9 - Balcões de Vistoria de Passaporte

\begin{tabular}{|c|c|c|c|}
\hline \multicolumn{4}{|c|}{ ÁREA DE VISTORIA DE PASSAPORTES } \\
\hline \multicolumn{4}{|c|}{ Aeroporto Internacional } \\
\hline \multicolumn{4}{|c|}{ Balcões para atendimento de passageiros } \\
\hline $\begin{array}{l}N^{\circ} \text { de agentes } \\
\text { (un.) }\end{array}$ & $\begin{array}{l}\text { Área } \\
\left(\mathbf{m}^{2}\right)\end{array}$ & $\begin{array}{c}\text { Tempo médio de atendimento } \\
\text { (seg) }\end{array}$ & $\begin{array}{c}\text { Processamento } \\
(\operatorname{pax} / \mathbf{h})\end{array}$ \\
\hline 2 & $8,00-14,70$ & 30 & 240 \\
\hline 4 & $15,00-27,30$ & 30 & 480 \\
\hline
\end{tabular}

Tabela 6.10 - Saguão de Desembarque (a)

\begin{tabular}{|l|c|c|c|}
\hline \multicolumn{2}{|c|}{ SAGUÃ DE DESEMBARQUE } \\
\cline { 2 - 4 } $\begin{array}{c}\text { Nivel de } \\
\text { serviço }\end{array}$ & \multicolumn{2}{|c|}{ Tipo de aeroporto } \\
\cline { 2 - 4 } & Internacional & Doméstico & Regional \\
\hline A - Alto & 2,00 & 1,80 & 1,50 \\
\hline B - Bom & 1,80 & 1,60 & 1,20 \\
\hline C - Regular & 1,50 & 1,20 & 1,00 \\
\hline
\end{tabular}


Tabela 6.11 - Saguão de Desembarque (b)

\begin{tabular}{|c|c|}
\hline$S A G U \widetilde{A} O$ & DESEMIBAIRQUE \\
\hline Nivel de serviço & $\begin{array}{l}\text { Quantidade de assentos } \\
\left(\% \text { do } n^{\circ} \text { de usuários }\right)\end{array}$ \\
\hline$A-$ Alto & 15 \\
\hline$B-$ Bom & 10 \\
\hline C-Regular & 5 \\
\hline
\end{tabular}

Tabela 6.12 - Restituição de Bagagens (a)

\begin{tabular}{|l|c|c|c|}
\hline \multicolumn{1}{|c|}{ ÁREA DE RESTITUICAO DE BAGAGENS } \\
\hline \multirow{2}{*}{$\begin{array}{c}\text { Nivel de } \\
\text { serviço }\end{array}$} & \multicolumn{2}{|c|}{ Tindices de dimensionamento $\left(\mathrm{m}^{2} / \mathrm{pax}\right)$} \\
\cline { 2 - 4 } & Internacional & Doméstico & Regional \\
\cline { 2 - 4 } & 2,00 & 1,60 & 1,30 \\
\hline A - Alto & 1,60 & 1,40 & 1,10 \\
\hline B - Bom & 1,30 & 1,10 & 0,80 \\
\hline C - Regular & & & \\
\hline
\end{tabular}

Tabela 6.13 - Restituição de Bagagens (b)

\begin{tabular}{|l|c|c|}
\hline \multicolumn{2}{|c|}{ ÁREA DE RESTITUIÇÃO DE BAGAGENS } \\
\hline Tipo de vôo & Quantidade de bagagens/pax & \% de carrinhos/pax \\
\hline Internacional & 1,2 & 80 \\
\hline Doméstico & 0,9 & 70 \\
\hline Regional & 0,5 & 60 \\
\hline
\end{tabular}


Tabela 6.14 - Alfândega

\begin{tabular}{|l|c|}
\hline \multicolumn{2}{|c|}{ AREA DE ALFANDEGA } \\
\hline \multicolumn{2}{|c|}{ Aeroporto Internacional } \\
\hline Nível de serviço & Indices de dimensionamento $\left(\mathbf{m}^{2} / \mathrm{pax}\right)$ \\
\hline A- Alto & 1,50 \\
\hline B-Bom & 1,20 \\
\hline C - Regular & 0,90 \\
\hline
\end{tabular}

Tabela 6.15 - Balcão de Alfândega

\begin{tabular}{|c|c|c|c|}
\hline \multicolumn{4}{|c|}{ ÁREA DE ALFÂNDEGA } \\
\hline \multicolumn{4}{|c|}{ Aeroporto Internacional } \\
\hline \multicolumn{4}{|c|}{ Balcões para atendimento de passageiros } \\
\hline $\begin{array}{l}N^{\circ} \text { de agentes } \\
\text { (un.) }\end{array}$ & $\begin{array}{l}\text { Área } \\
\left(\mathbf{m}^{2}\right)\end{array}$ & $\begin{array}{l}\text { Tempo médio de atendimento } \\
\qquad(\mathrm{min})\end{array}$ & $\begin{array}{c}\text { Processamento } \\
(\operatorname{pax} / \mathbf{h})\end{array}$ \\
\hline 2 & $17,48-29,16$ & 2 & 60 \\
\hline
\end{tabular}

Tabela 6.16 - Sanitários Masculinos

\begin{tabular}{|l|c|c|c|c|}
\hline \multicolumn{5}{|c|}{ SANITÁrios MASCULINOS } \\
\hline & \multicolumn{2}{|c|}{ Índices de dimensionamento $\left(\mathbf{m}^{2}\right)$} \\
\hline Nivel de serviço & Lavatório & B. sanitária & Mictório & Circulação \\
\hline A - Alto & 1,40 & 2,00 & 1,10 & 2,38 \\
\hline B - Bom & 1,20 & 1,80 & 0,90 & 2,11 \\
\hline C - Regular & 1,00 & 1,50 & 0,70 & 1,55 \\
\hline
\end{tabular}

Tabela 6.17 - Sanitários Femininos 


\begin{tabular}{|l|c|c|c|}
\hline \multicolumn{3}{|c|}{ SANITÁrios FEMININOS } \\
\hline \multicolumn{2}{|c|}{ Índices de dimensionamento $\left(\mathbf{m}^{2}\right)$} \\
\hline Nivel de serviço & Lavatório & B. sanitária & Circulação \\
\hline A - Alto & 1,40 & 2,00 & 1,85 \\
\hline B - Bom & 1,20 & 1,80 & 1,68 \\
\hline C - Regular & 1,00 & 1,50 & 1,20 \\
\hline
\end{tabular}

Para a estimativa inicial de planejamento, recomendam-se os seguintes índices para área de concessões de terminal de passageiros em aeroportos:

- Aeroportos internacionais - Para aeroportos com elevados volumes de tráfego, propõem se de 40 a $60 \%$ da área total dos componentes operacionais;

- Aeroportos domésticos - Para aeroportos com médios volumes de tráfego, indicamse de 20 a $40 \%$ da área total dos componentes operacionais;

- Aeroportos regionais - Para aeroportos com pequenos volumes de tráfego, recomendam se de 15 a $25 \%$ da área total dos componentes operacionais.

\subsubsection{Modelos Analíticos de Teoria de Filas e o $\mathrm{Hub}$}

Os métodos de teoria de filas quantificam os tempos de chegada de passageiros aos pontos de processamento, bem como o número de passageiros na fila formada e o tempo de espera até o mesmo ser atendido segundo uma taxa de serviço definida. Com a teoria de filas pode-se estimar atrasos e tempos de processamento que então, tratados por índices que resultam em áreas físicas dos componentes em questão. Os modelos de teoria de fillas se dividem em determinísticos e estocásticos. Eles são fundamentais para dimensionar ou analisar a infraestrutura sobrecarregada pela concetração provocada pelo hub.

Modelos de teoria de filas são típicos para uso no check in e na área de restituição de bagagens.

Exemplo de modelo determinístico de teoria de filas: 
De uma pesquisa tem-se que a distribuição de chegada de passageiros ao balcão de check-in de um determinado tipo de vôo é dada pela curva de chegada, que mostra a chegada de passageiros acumulada em função da antecedência a HPP.

Também através de medidas experimentais se determina que o atendimento de um balcão de check-in é dado pela curva de serviço, no caso suposta constante e com taxa de serviço de $\mathrm{n}$ pax/min (inclinação da curva). Neste exemplo deve-se ressaltar que a hora de abertura do check-in coincide com o tempo t. Neste tempo $t$ calcula-se o tamanho da fila existente e o tempo que um passageiro aguardará para ser atendido. Fica claro também que aumentando o número de balcões ativos aumentará também a inclinação da curva de serviço (a curva será rotacionada no sentido anti-horário).

Modelos estocásticos de teoria de filas são aqueles onde as curvas de chegada e de serviço são distribuições probabilísticas inserindo assim no modelo uma incerteza mais condizente com o mundo real através de erros estocásticos e desvios padrões.

\subsubsection{Empíricos}

Modelos empíricos são aqueles que se baseiam em dados experimentais. São os mais utilizados pelos profissionais de planejamento e de operações de TPS por serem de fácil manipulação e não requisitarem grandes quantidades de dados de entrada.

Entre os modelos empíricos mais difundidos estão os baseados no conceito de "Hora Pico". Este conceito fundamenta-se no fato de que o TPS não será projetado para o maior movimento instantâneo previsto e sim para um valor representativo de intensa movimentação que ocorre com alguma freqüência. Dependendo da fonte o conceito de "Hora Pico" é entendido de uma forma. Dentre as fontes mais relevantes estão:

- $\quad$ DAC/ANAC - hora mais ocupada do dia médio do mês pico;

- $\quad$ FAA - hora mais ocupada do dia mais ocupado da semana típica;

- Horonjeff - trigésima hora mais movimentada do ano (baseado no planejamento de rodovias).

Existem diversas correlações entre o movimento da "Hora Pico" e o movimento anual. 
A modelagem deve levar em conta a concentração de passageiros de conexão quando o aeroporto apresentar operação do tipo hub, considerando que a Hora Pico será muito ampliada com a operação em vagas que, ao concentrar em curto intervalo de tempo maior quantidade de vôos, faz crescer a quantidade de passageiros movimentando-se no aeroporto.

Na tabela a seguir é evidenciada essa correlação segundo a FAA para a TPHP:

A seguir é apresentada a tabela de passageiros Anuais TPHP como percentagem do fluxo anual.

Tabela 6.18 - Porcentagem do Fluxo de Passageiros

\begin{tabular}{|c|c|}
\hline Passageiros Anuais & $\begin{array}{c}\text { TPHP como percentagem do fluxo } \\
\text { anual }\end{array}$ \\
\hline Acima de 30 milhões & 0,035 \\
\hline De 20.000.000 a 29.999.999 & 0,040 \\
\hline De 10.000.000 a 19.999.999 & 0,045 \\
\hline De 1.000.000 a 9.999.999 & 0,050 \\
\hline De 500.000 a 999.999 & 0,080 \\
\hline De 100.000 a 499.999 & 0,130 \\
\hline Abaixo de 100.000 & 0,200 \\
\hline
\end{tabular}

Um exemplo de modelo empírico de Hora Pico:

Tem-se para, área de pré-embarque ou área de fila do check-in, índices de 1,0, 1,8 e 1,0 m2, respectivamente, por passageiro na hora-pico, segundo o nível de serviço preconizado pela FAA (Ashford, 1992). Pela demanda do período obtêm-se as estimativas de áreas desejadas.

Outros modelos, como o MMS avaliam o instante de maior solicitação dos componentes através de propagações e sobreposições dos fluxos relativos aos diversos vôos. Procura captar a maior movimentação que realmente ocorre por componente, sempre inferior a carga da 
hora-pico. Encontrado o número de passageiros/usuários no momento crítico, utilizam-se índices tabelados para se obter as áreas necessárias. Existem trabalhos que usam como referência os 15 minutos críticos.

Exemplo de modelo empírico de MMS - taxa de atendimento: 5 passageiros a cada 5 minutos por balcão, e conseqüentemente, gera sobrecarga ou maior demanda no hub.

Tabela 6.19 - Taxa de Atendimento Modelo Empírico 


\begin{tabular}{|c|c|c|c|c|c|}
\hline Horário & $\begin{array}{l}\text { Checkin } \\
\text { chegada }\end{array}$ & $\begin{array}{c}\text { Numero de } \\
\text { balcões } \\
\text { ativos }\end{array}$ & $\begin{array}{l}\text { Checkin } \\
\text { processo }\end{array}$ & $\begin{array}{c}\text { Checkin } \\
\text { fila }\end{array}$ & $\begin{array}{c}\text { Checkin } \\
\text { saída }\end{array}$ \\
\hline $07: 30$ & 0 & 0 & 0 & 0 & 0 \\
\hline $07: 35$ & 0 & 0 & 0 & 0 & 0 \\
\hline $07: 40$ & 0 & 0 & 0 & 0 & 0 \\
\hline $07: 45$ & 0 & 0 & 0 & 0 & 0 \\
\hline $07: 50$ & 6 & 1 & 5 & 1 & 5 \\
\hline $07: 55$ & 0 & 1 & 5 & 0 & 1 \\
\hline 08:00 & 6 & 1 & 5 & 1 & 5 \\
\hline $08: 05$ & 0 & 1 & 5 & 0 & 1 \\
\hline $08: 10$ & 36 & 2 & 10 & 26 & 10 \\
\hline $08: 15$ & 0 & 2 & 10 & 16 & 10 \\
\hline $08: 20$ & 12 & 2 & 10 & 18 & 10 \\
\hline $08: 25$ & 0 & 2 & 10 & 8 & 10 \\
\hline \multirow[t]{5}{*}{$08: 30$} & 0 & 2 & 10 & 0 & 8 \\
\hline & 60 & 2 & 70 & 26 & 60 \\
\hline & & & Área: & 81,5 & \\
\hline & & balcões & comprimento & 5 & \\
\hline & & & largura: & 16,3 & \\
\hline
\end{tabular}

Hart (1985) traz diversos índices empíricos de dimensionamento das áreas de componentes de terminais de passageiros.

\subsubsection{Simulação}


Modelos de Simulação são aqueles que, utilizando representações matemáticas e lógicas do mundo real, convertem parâmetros e dados de entrada em saídas que caracterizam o sistema em questão. Em síntese buscam retratar o comportamento real do sistema, prevendo-se conseqüências e resultados.

A Simulação possui dois enfoques básicos: discreta, onde o sistema pode ser descrito por mudanças de estado que ocorrem em tempo discreto; ou contínua, onde o comportamento do sistema é descrito por variáveis de estado cujo comportamento dinâmico simulam o mundo real. No caso de TPS, são mais utilizados os modelos de simulação discretos, pois elaborar um conjunto de equações que descrevam o sistema do TPS é tarefa complexa ou quase impossível.

Normalmente os modelos de simulação se utilizam de recursos computacionais para agilizar o trabalho do planejador/operador, e dentro do ambiente computacional existem programas de simulação gerais e programas específicos para TPS.

\subsubsection{Outros}

Existem modelos que são utilizados na detecção e na análise de inter-relação entre componentes de um TPS, através da construção de uma rede de interligações entre os mesmos. Estes modelos são denominados modelos de malha, e entre eles destacam-se os modelos tipo CPM (modelo do percurso crítico). 


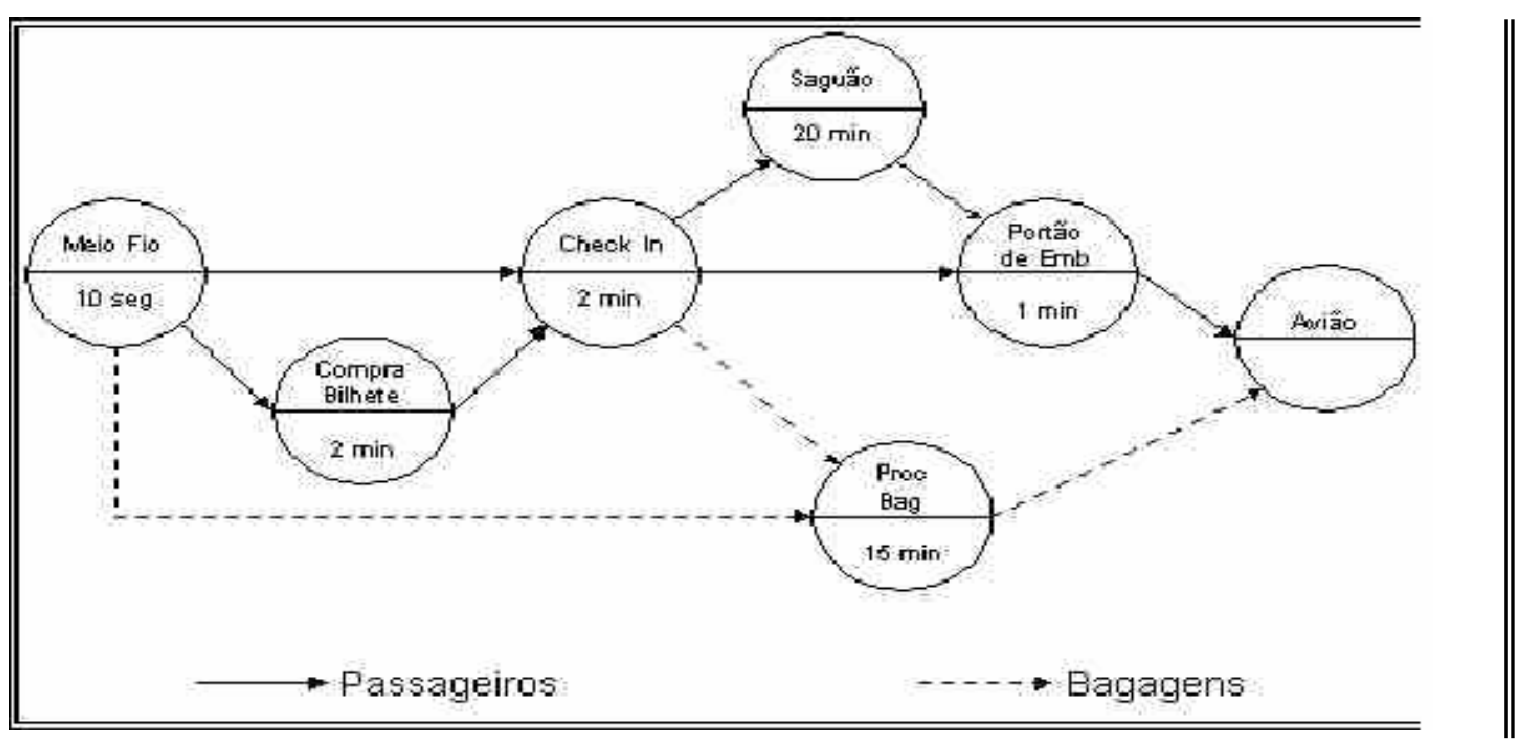

Figura 6.3 - Modelo de Percurso Crítico dos Componentes de Um TPS

6.6 MANUTENÇÃO DO COMPLEXO AEROPORTUÁRIO E O HUB

Os aeroportos são administrados pelo município onde estes operam (ou atendem), ou por empresas especialmente criadas para esse fim, podendo ser públicas ou privadas. Devido ao grande impacto econômico de um grande centro aeroportuário numa cidade, região e/ou país, os aeroportos são geralmente administrados por empresas públicas, ou fortemente influenciados por órgãos públicos quando administrados por empresas privadas.

Quando a capacidade de passageiros, carga ou movimento de aeronaves do aeroporto está perto de sua capacidade total, algumas mudanças podem ser necessárias, como a expansão de terminais de passageiros e/ou carga, novas taxiways, pistas de pouso e decolagem e estacionamentos. Quando isto não é possível, considera-se a construção de um novo aeroporto na região.

A manutenção econômica de um aeroporto dá-se através das taxas cobradas para o pouso e estacionamento de uma dada aeronave; os preços variam de aeroporto para aeroporto e de aeronave para aeronave. A cobrança de impostos ao comércio e tarifas de embarque de passageiros, bem como a renda gerada pelo estacionamento de carros, também contribui de maneira significativa para a manutenção econômica de um aeroporto que, no final das contas, pode tornar-se muito lucrativa; o Aeroporto Internacional de São Paulo-Guarulhos, em 
Guarulhos, é responsável por aproximadamente 30\% da receita total da Infraero (que controla 67 aeroportos brasileiros).

6.7 SEGURANÇA AEROPORTUÁRIA E AS EXIGÊNCIAS DO HUB

6.7.1

\section{Controle da Segurança da Aviação Civil no Brasil}

\section{a - Security}

Objetivando prevenir e dissuadir a prática de atos de interferência ilícita contra a Aviação Civil, com vistas a sua erradicação, o Brasil, ao atualizar sua legislação de segurança da Aviação Civil, incorporou à mesma as novas Normas e Práticas Recomendadas pela OACI, garantindo que as medidas de segurança a serem implementadas sejam compatíveis e proporcionais aos níveis de ameaça identificados em seu território.

Conforme a legislação brasileira, cabe à administração aeroportuária:

- $\quad$ Estabelecer e manter o PSA, detalhando as medidas de segurança no aeroporto;

- Nomear, no aeroporto, um responsável pela segurança da Aviação Civil, encarregado de coordenar a implementação dos procedimentos estabelecidos no respectivo PSA;

- Assegurar o estabelecimento e o funcionamento da CSA, no caso de aeroportos com operação de aeronaves com mais de sessenta assentos;

- Garantir a inclusão das necessidades e dos requisitos de segurança da Aviação Civil em projetos e construção de novas instalações aeroportuárias, bem como na reforma ou ampliação das existentes, submetendo-as à prévia aprovação da ANAC;

- Acompanhar a elaboração dos procedimentos de segurança previstos nos PSEA e supervisionar a sua implementação no respectivo aeroporto;

- $\quad$ Explicitar no seu PSA as responsabilidades referentes à segurança da Aviação Civil das suas contratadas, empresas de serviços auxiliares de transporte aéreo;

- $\quad$ Fiscalizar e supervisionar a implementação das medidas de segurança estabelecidas no PSA, para os seus concessionários e empresas de serviços auxiliares de transporte aéreo contratado pela administração aeroportuária; 
- Realizar as avaliações, auditorias internas e testes com o objetivo de verificar a eficácia das medidas estabelecidas no PSA, sob a supervisão da ANAC;

- Coordenar a participação dos órgãos públicos que, por disposição legal, devam funcionar no aeroporto com o intuito de atuar nas atividades de segurança aeroportuária, consubstanciando-as no PSA;

- Informar aos órgãos e operadores aéreos que tiverem acesso ao PSA, ou parte dele, a legislação relativa aos documentos sobre salvaguarda de assuntos sigilosos e as respectivas penalidades;

- Implementar os controles gerais de acesso nos aeroportos, envolvendo passageiros, tripulantes, empregados da administração aeroportuária, outras pessoas, veículos, bagagens, carga, correio e outras mercadorias;

- $\quad$ Fornecer e manter os equipamentos para a realização de inspeções de segurança da Aviação Civil;

- $\quad$ Prover os recursos humanos, treinados na atividade de proteção da Aviação Civil para a realização de inspeções de segurança nos passageiros e suas bagagens, bem como nas demais pessoas que necessitem entrar nas ARS, exceto nos casos em que isto seja realizado por efetivo da PF;

- Impedir o acesso às ARS de passageiros que não satisfaçam aos requisitos de segurança da Aviação Civil, comunicando à empresa aérea, em formulário apropriado, para que seja negado o seu embarque, por não satisfazer as condições gerais de transporte; e

- Implantar e manter o COE, que se constitui no setor de segurança aeroportuária que, em situações de emergência, permite o gerenciamento de crises, incluindo aquelas decorrentes de atos de interferência ilícita contra a Aviação Civil.

- Anualmente realizar exercícios simulados com os integrantes que participam das ações preventivas e corretivas por força da legislação, visando aferição dos procedimentos estabelecidos nos programas e planos de segurança da aviação civil. 


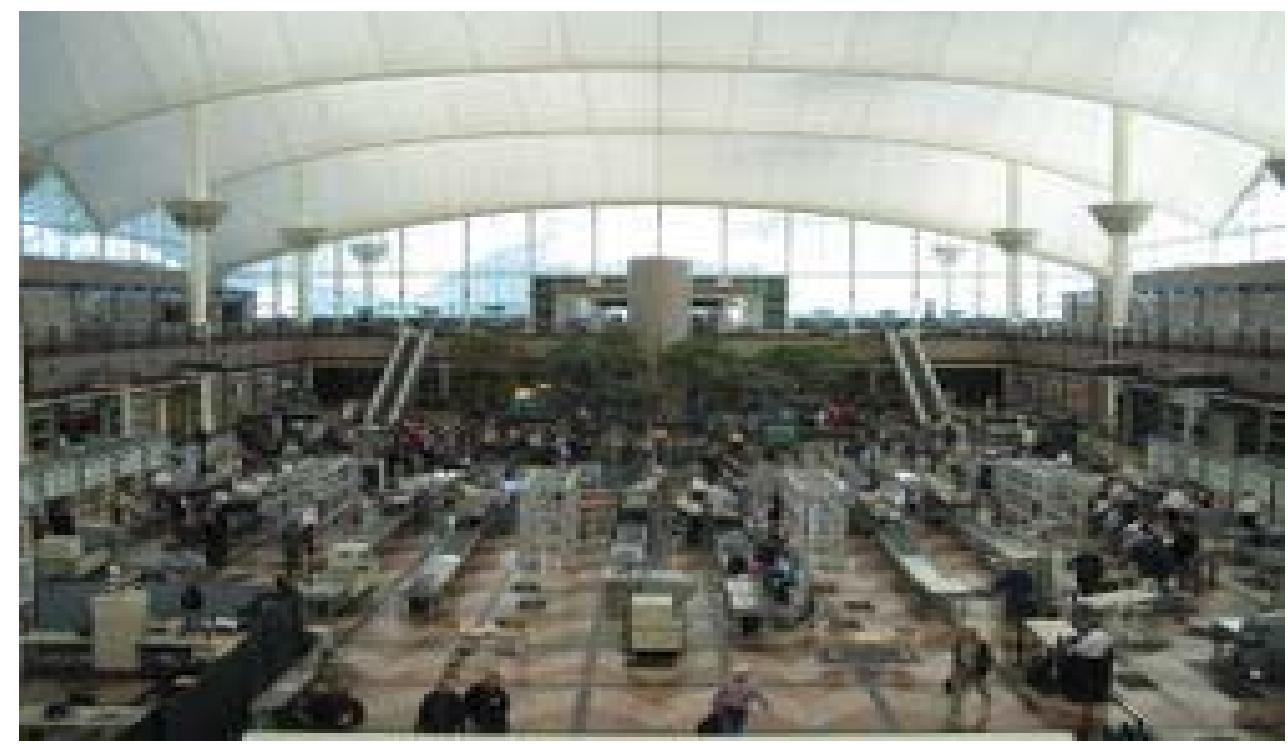

Figura 6.4 - Área de Revista de Bagagem (Denver-EUA)

Do ponto de vista de aeroporto hub, é importante salientar alguns requisitos especiais:

o Inspecionar todos os passageiros de conexão com uso de equipamentos que deverão estar disponibilizados e as equipes preparadas.

o A administração aeroportuária deverá garantir a esterilização do fluxo de passageiros em áreas restritas de segurança, em especial o fluxo dos corredores.

o As instituições públicas com atuação no processo de internacionalização e nacionalização deverão estar disponíveis com o número suficiente de servidores para atender à demanda de passageiros, em especial no atendimento de passageiros em conexão internacional.

A segurança em grandes aeroportos de passageiros é um assunto muito sério, se levarmos em conta questões como a segurança de vôo ou o terrorismo, principalmente em aeroportos que tem suas operações baseadas no sistema hub, considerando aeronaves de bandeira internacional procedentes de paises que vivem em situações sob ameaças.

Terminais de passageiros movimentados fazem uso de máquinas de raios- $\mathrm{x}$, para a verificação de materiais perigosos, detectores de metais para a detecção de armas e animais treinados a detectar traços de explosivos em um dado passageiro, bagagem ou carga. Os seguranças do aeroporto também podem ordenar uma revista completa numa pessoa e/ou na bagagem desta. 
Além de objetos considerados armas (armas de fogo, facas, tesouras, etc), também são proibidos objetos que ponham em risco a integridade do vôo, como isqueiros, materiais inflamáveis ou explosivos, etc. Problemas como a falta de verbas pode fazer com que tais medidas de segurança não sejam utilizadas como deveriam, aumentando muito o risco de atentados ou seqüestros.

\section{B - Safety}

Outras questões envolvendo segurança nos aeroportos incluem a área de aproximação de pouso de aeronaves, nem sempre livre de obstáculos (como, por exemplo, o antigo aeroporto de Hong Kong, com montanhas de grande altitude durante a aproximação), ou a relação entre o número de operações de pousos e decolagens num dado aeroporto e o tamanho da sua pista. No Brasil os Aeroportos de Santos Dumont, no Rio de Janeiro, cuja pista possui 1,3 mil metros de comprimento e Congonhas - São Paulo, podem ser consideradas insegura para a operação dos Boeing 737, A319 e -A320 que aí costumam operar.

6.8

\section{ACESSIBILIDADE AEROPORTUÁRIA}

A eficiência do transporte aéreo está intimamente ligada à acessibilidade a seus terminais aeroportuários. Espera-se que os modais de superfície ofereçam um nível de serviço adequado e compatível com o oferecido pelo modo aéreo no acesso aos aeroportos, principalmente no que tange à rapidez, promovendo a viagem porta-a-porta dos usuários e/ou seus bens e cargas. Este conceito deu lugar ao "tempo e qualidade de acesso", adequando-se à realidade e exigência do usuário do transporte aéreo. Com relação ao hub, ele é pouco afetado pelo quesito acessibilidade, visto que a provável sobrecarga tem origem em passageiros de conexão, porém, o aeroporto deverá ser dotado de serviço adequado de transporte de superfície em função da demanda.

\subsubsection{Conceito de Acessibilidade}

Segundo Pavarino (1996), a acessibilidade é a qualidade do acessível, a tentativa de equalização entre a capacidade viária e demanda que nela circula, também aspectos relativos à possibilidade de estacionamento ou ainda a segurança do deslocamento. 
Conforme Linhares (1989), acessibilidade é considerada o resultado das facilidades proporcionadas pela infra-estrutura física do sistema de transportes - Teoria do transporte avaliação feita com parâmetros homogêneos para diferentes pessoas, em diferentes lugares e momentos demonstra a fragilidade deste sistema de avaliação.

Apesar do hub não exigir grande infra-estrutura de acessibilidade, o aeroporto deverá ser dotado de acessibilidade compatível com a demanda para atendimento a passageiros com destino final ao hub, além de transporte dos profissionais da comunidade aeroportuária bem como de suprimentos necessários ao funcionamento do aeroporto.

As auto-estradas são vias de comunicação destinadas apenas a tráfego motorizado, dotada de duas vias (pelo menos) em cada sentido, separadas por elementos físicos, com cruzamentos desnivelados e acesso restrito a nós de ligação, não possui cruzamentos (e sim rampas de acesso), e serve primariamente para atender ao tráfego entre áreas urbanas ou dentro de uma metrópole. Assim, as auto-estradas não devem ser confundidas com vias expressas nem com sistemas nacionais de estradas. Freqüentemente, a diferença entre vias expressa e autoestradas é que as primeiras permitem a circulação de pedestres e ciclistas ao longo da via pública.

Numa auto-estrada os limites de velocidade são geralmente maiores que os de outras estradas e, normalmente, possuem portagem e são concessionadas a uma empresa que as explora comercialmente e conserva. Muitas auto-estradas não são construídas de raiz, podendo ser construídas a partir da reconversão de sistemas de estradas ou rodovias nacionais. Hub, os Seguintes Sistemas Segundo o CBA

A constituição de sistema hub sobrecarrega a infra-estrurua aeroportuária ao concentrar chegadas e saídas em intervalo muito curto, gerando no Brasil, várias dezenas de movimentos por hora em função do atendimento ao hub. 
- Sistema aeroportuário: constituído pelo conjunto de aeródromos brasileiros, com as pistas de pouso e pistas de táxi, pátio de estacionamento, terminal de carga e passageiros e demais facilidades; aeródromo é toda área destinada a pouso, decolagem e movimentação de aeronave e são classificados em civis e militares, sendo os civis classificados em públicos e privados;

- Sistema de controle de tráfego aéreo: visa a regularidade, segurança e eficiência do fluxo de tráfego no espaço aéreo;

- Sistema de segurança, de vôo: tem por objetivo promover a segurança de vôo, devendo a autoridade aeronáutica estabelecer os padrões mínimos de segurança a serem observados;

- Sistema de Registro Aeronáutico Brasileiro (RAB): trata-se de registro público, único e centralizado, destinando-se a ter em relação à aeronave as funções de emitir certificados de matrícula, aeronavegabilidade e nacionalidade de aeronaves sujeitas à legislação brasileira, bem como, as inscrições de contratos, propriedade e ônus reais sobre aeronaves;

- Sistema de facilitação, segurança e coordenação do transporte aéreo: tem por objetivo estudar as normas e recomendações pertinentes da OACI e propor aos órgãos interessados as medidas adequadas a implementá-las no País, avaliando os resultados e sugerindo as alterações necessárias ao aperfeiçoamento dos serviços aéreos;

- Sistema de serviços auxiliares: assim considerados as agências de carga aérea, os serviços de rampa ou de pista nos aeroportos e os relativos à hotelaria e restaurantes nos aeroportos.

\subsection{2}

\section{Controle de Tráfego Aéreo - TWR}

Em aeroportos, as torres de controle organizam o movimento de aeronaves no solo e no espaço aéreo quando estas se aproximam do aeroporto e autorizam operações de pouso e decolagem. Torres de controle situam-se em uma localização do aeroporto que permita ampla visão do aeroporto como um todo, bem como ampla visão das aeronaves que se aproximam do aeroporto numa operação de pouso. Numa emergência, ordenam que equipes de emergência do aeroporto estejam prontas para a situação. Porém, é necessário observar que vários aeródromos de pequena dimensão e campos de aterrisagem, bem como alguns aeroportos de médio porte, não possuem torre de controle ou controle de tráfego aéreo. 


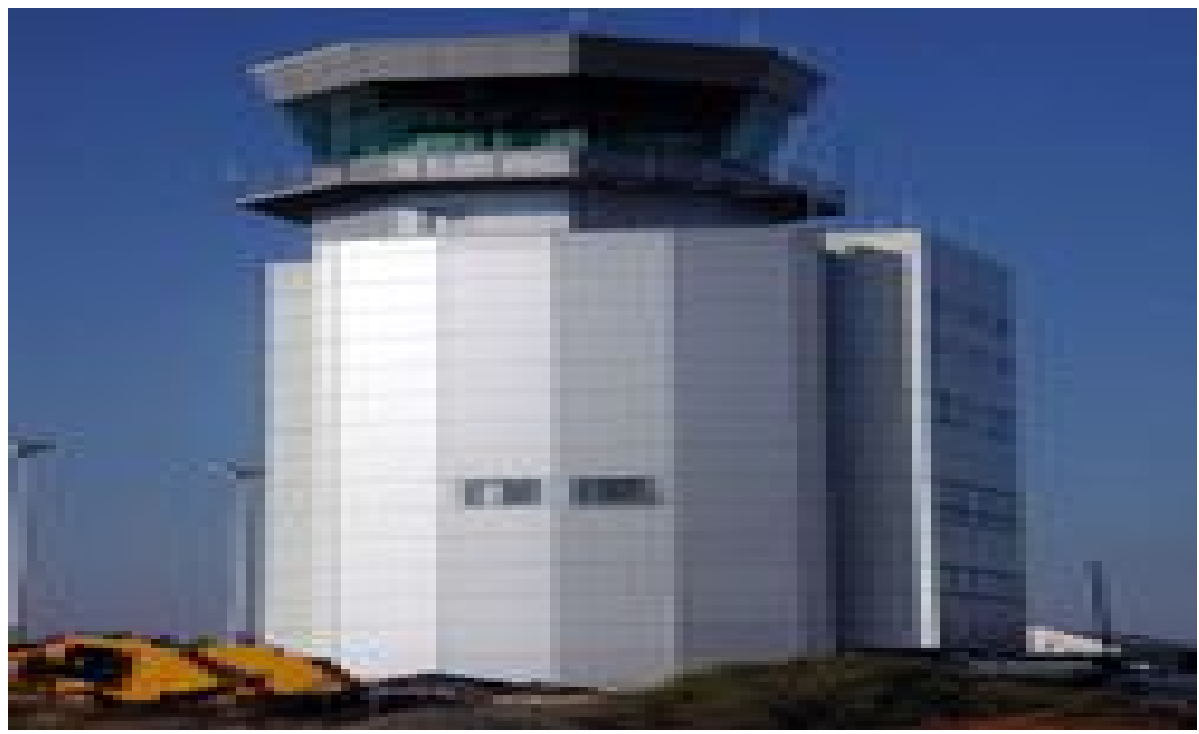

Figura 6.5 - Torre de Controle do Aeroporto de Bristol, Inglaterra

\subsubsection{Navegação Aérea - CNS/ATM - Benefícios ao Hub}

Novo sistema de gerenciamento de tráfego aéreo a ser adotado internacionalmente, o CNS/ATM (Comunicações, Navegação, Vigilância/Gestão de Tráfego Aéreo) utiliza recursos de gestão de vôo apoiados em satélites de comunicações, incorporando a tecnologia de dados GPS (Satélites de Posicionamento Global) para navegação. Esse sistema utiliza dados transmitidos pelas aeronaves por meio de datalinks, recebe, processa, compõe com dados recebidos de outras fontes e disponibiliza para visualização a situação para o controlador de tráfego aéreo. Esses dados, unificados, permitem a troca de informações precisas entre aeronaves e controladores em terra, reforçando a segurança do tráfego aéreo e aumentando a agilidade e eficácia das comunicações em vôo. Segundo planejamento da OACI, de forma gradual ao longo dos próximos anos, o novo sistema - que também começa a ser adotado pelos centros de controle aéreo latino-americano - estará implantado mundialmente de forma integrada.

Devido à alta concentração de vôos provocada pela sobrecarga de aeronaves no espaço aéreo com destino ao hub, o referido sistema é fundamental para garantir a eficiência no gerenciamento e segurança das aeronaves em vôo.

A Atech já está presente na implantação do modelo, participando ativamente dos eventos de concepção e definição de requisitos operacionais, e desenvolvendo os novos sistemas de 
gerenciamento de tráfego para as aeronaves que circulam no espaço aéreo brasileiro e alguns países vizinhos.

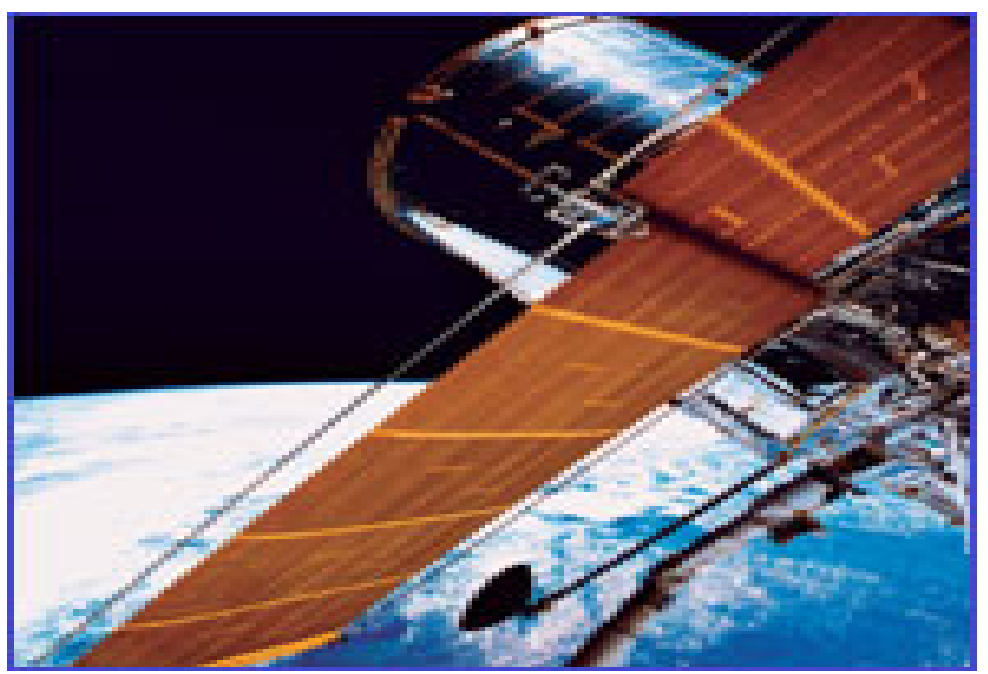

Figura 6.6 - CNS/ATM

A organização do Espaço Aéreo Brasileiro está sendo preparada e modernizada durante estes anos para que em 2010, esteja preparado para adotar o Sistema de Aeronavegação do CNS/ATM.

Estão previstas várias modificações em termos de aproveitamento maior do Espaço Aéreo disponível, seja nas Terminais mais complexas com um fluxo de Aeronaves em crescimento cada vez mais acentuado ou mesmo nas Rotas Aéreas Internacionais que cruzam o Espaço Aéreo Brasileiro e se dirigem para outros Continentes. Exemplos recentes de modificações nas Aerovias já estão sendo utilizados pelas tripulações da Varig e da Tam nos vôos que partem do Brasil em direção ao Continente Europeu e também na direção do Pacífico Norte, cuja separação mínima entre as Aeronaves voando no FL 290 até o FL 410, agora é de 1000 Pés.

Estas novas Regras de Vôo são denominadas como RVSM e estão inseridas nas Regras do Sistema CNS/ATM, assim como, as novas Regras de Separação Lateral adotadas no Pacífico Norte denominadas RNP, onde as aeronaves homologadas estão voando com separação de dez milhas laterais a partir do eixo da Aerovia e durante a maior parte do tempo de vôo na trajetória escolhida. 
Na parte relativa as comunicações, a grande modernização do Sistema será a plena adoção de Sistemas de Transmissão de Dados por Satélites, passando a existir uma interação simultânea entre as Aeronaves, Bases de Operações, Órgãos de Controle de Tráfego Aéreo e Administração de Terminais Aeroportuários, onde todos estarão trocando informações em tempo real e sem as interferências causadas pelas limitações do Sistema utilizado atualmente.

De concreto, já existem hoje em dia instalados em aviões das grandes Companhias Aéreas, o ACARS, que é um Sistema de Transmissão de Dados Digitais e em terra já estão sendo instaladas nas estações DATACOM para operar em conjunto, formando o Sistema de Transmissão e Recepção de Dados Digitais. Já em plena utilização e mais desenvolvidos estão os Sistemas de Navegação Aérea que darão suporte necessário ao CNS/ATM.

Para voar em Rotas Diretas e efetuar aproximações mais precisas já se utiliza o GNSS atuando em conjunto com Estações Terrestres para a correção das informações fornecidas pelos GPS.

Portanto, adotando novas tecnologias o CNS/ATM, está sendo implantado aos poucos e a sua utilização trará benefícios como: aumento do nível de segurança dos vôos, economia de tempo e combustível, menor congestionamento nas terminais e nas aerovias, além de padronizar os procedimentos operacionais em todo o mundo, o que é a proposta da OACI, que no Brasil é representada pelo DECEA (Filho, 2007). 
Este trabalho de pesquisa apresentou a viabilidade para adoção do sistema hub and spoke, no qual, foram analisados os parâmetros necessários à criação e operação do mesmo.

A desregulamentação dos serviços aéreos no Brasil promovido recentemente pela ANAC, possibilitou às empresas aéreas a flexibilização em relação à participação no mercado, à quantidade e qualidade de serviços oferecidos e aos preços das tarifas aéreas. As mudanças vivenciadas pelo mercado brasileiro guardam certas semelhanças com fatos ocorridos, nas décadas de 80 e 90 nos Estados Unidos. Portanto, no Brasil, basicamente existem apenas 3 (três) aeroportos que operam como hub, sendo os Aeroportos de Brasília, Guarulhos e Congonhas.

Foi realizada uma pesquisa bibliográfica sobre a infra-estrutura necessária para adequação de um aeroporto ao sistema hub and spoke, tomando como base vários aeroportos espalhados pelo mundo, além de considerar também o sistema aeroportuário e a estrutura da aviação civil brasileira.

A pesquisa deu ênfase à avaliação e estudo sobre a preparação de infra-estrutura necessária a operação no sistema hub, como sistema de controle de espaço aéreo, transporte e acessibilidade ao aeroporto, recursos para atendimento às emergências aeronáuticas e outras emergências, infra-estrutura aeroportuária (terminal de passageiros, pátios e pistas, auxílios visuais, pontes de embarque, terminal de carga aérea, etc).

Uma avaliação do ponto de vista econômico foi realizada, visto que o sistema hub and spoke é visto como sendo um indutor do crescimento econômico para região de operação do mesmo, ou seja, poderá gerar um impacto considerável nos quesitos população, demografia e economia regional. O sistema caracteriza-se também por ser um agente de competição entre as empresas aéreas, e entre os aeroportos.

Após análise detalhada do sistema em estudo, observa-se que este sistema é viável tanto para as companhias aéreas quanto para os passageiros. Do lado das companhias aéreas, elas ganharão poder de barganha em relação à concorrência, principalmente em relação às companhias low-fare/low-cost, que nos casos de crises poderão concentrar maior número de 
suas operações no hub a fim de obter uma maior lucratividade. Visando os passageiros, eles terão maiores opções de vôos para os seus respectivos destinos.

Para que se tenha sucesso no sistema $h u b$, um critério de parâmetros rigorosos deverão ser adotados, considerando a imprescindibilidade da existência de padrões adequados para a seguinte infra-estrutura:

$\rightarrow$ Infra-estrutura - Anexo 14 (pátios e pistas para pouso e decolagem simultânea, dimensões TPS, acessibilidade, conectividade, acesso adequado ao aeroporto, facilidades operacionais, sistema de controle de aeronaves no espaço aéreo, facilidade de manutenção, segurança aeroportuária (safety e security - Anexo 17), transporte por ônibus e metrô, instituições, facilidades de acordo com Anexo 9.

O trabalho mostrou de forma enfática os mais variados aeroportos que operam no sistema hub and spoke pelo mundo, porém, os mais movimentados, são exatamente aqueles dotados de toda infra-estrutura necessária ao sistema hub, conforme mencionado acima. Conclui-se portanto, que, para o êxito e crescimento do aeroporto hub, é necessário infra-estrutura adequada, e por outro lado, o sistema trás crescimento de desenvolvimento econômico para a infra-estrutura existente, ou seja, é recíproco.

A caracterização de aeroportos hub e non hub, tanto no Brasil quanto no exterior, é definida pelos parâmetros do FAA que classifica um aeroporto hub pelo quantitativo de passageiros em conexão. Baseado no conceito e classificação do FAA para Aeroporto hub, e nas análises realizadas com relação aos aeroportos brasileiros administrados pela Infraero, entende-se que os aeroportos de Brasília, Galeão, Guarulhos, Congonhas e Confins, apresentam potencial para operação no sistema hub and spoke.

Outros fatores importantes que devem ser considerados para infra-estrutura de um aeroporto hub, são os impactos do ponto de vista econômico e ambiental, que deverão ser atendidos e considerados no sistema de gestão dos aeroportos, além da preocupação com crescimento desordenado do entorno, visando a manutenção e conformidade prevista no plano diretor do aeroporto e região. 
A programação de vôos é de fundamental importância para o sucesso competitivo de uma companhia aérea e principalmente para operar no sistema hub. Desta forma, no cenário brasileiro recomenda-se a promoção de uma metodologia formal para a atividade, buscando o alinhamento com as líderes mundiais no setor de aviação comercial. A simples aplicação de ferramentas de Logística e Engenharia de Produção na tentativa de solucionar as complexidades de criação de uma rede de linhas ideal não é suficiente, portanto, a utilização de métodos científicos em conjunto com o conhecimento empírico e o auxílio de softwares de análise integrada da malha de vôos são as tendências inevitáveis para aquelas empresas que desejarem sobreviver e prosperar neste mercado cada vez mais competitivo, considerando a perspectiva de ter suas operações baseadas no sistema hub and spoke.

No trabalho de pesquisa, ficou evidenciado também que para operar em um sistema hub, é necessário um bom sistema de gerenciamento de espaço aéreo, compatível com os aeroportos e aeronaves, tanto nacional quanto internacional.

Portanto, os principais critérios para preparação de aeroportos para operar como hub and spoke são:

- $\quad$ Localização geográfica do aeroporto.

- Infra-estrutura aeroportuária:

- Capacidade operacional dos pátios e pistas de pouso e decolagem de aeronaves;

- Capacidade de processamento de embarque e desembarque de passageiros (pontes de embarque, posições remota, recuada e aviação geral):

- $\quad$ Pistas de pouso e decolagem que tenha condições para operações simultâneas;

- $\quad$ Estrutura com capacidade de armazenagem e combustível e reabastecimento de aeronaves;

- $\quad$ Sistema de restituição de bagagem compatível com o Hub;

- $\quad$ Serviço de transporte de superfície de passageiros;

- $\quad$ Serviços de Security e Safety compatível com o Hub;

- O Órgãos públicos necessários aos aeroportos internacionais;

- $\quad$ Equipe de manutenção para atendimento imediato. 
- Infra-estrutura aeronáutica:

- $\quad$ Controle de tráfego aéreo e segurança de vôo;

- $\quad$ Equipamentos de auxílio à navegação atualizados tecnologicamente;

- $\quad$ Sistema de Aeronavegação CNS-ATM.

- $\quad$ Empresas Aéreas:

- $\quad$ Otimização da rede de linhas aéreas;

- $\quad$ Disponibilização de aeronaves para atendimento da demanda gerada pelo Hub;

- $\quad$ Disponibilidade da frota para alto índice de utilização;

- $\quad$ Base de manutenção de aeronaves adequada para o Hub.

De uma forma geral, os resultados dos estudos realizados, contemplando o cenário nacional e internacional dos mais variados aeroportos, mostram a viabilidade do ponto de vista técnico e econômico da operação de aeroportos no sistema hub and spoke. Porém, para garantir essa viabilidade, deve-se comprovar o potencial do aeroporto e avaliar de forma minuciosa o atendimento aos critérios mencionados acima, necessário à infra-estrutura para operação no sistema hub and spoke. 
Almeida, P. H., 2006, Aeroportos e Desenvolvimento Local - O Caso de Salvador, Faculdade de Ciências Econômicas da UFBA, home page www.sei.ba.gov.br/publicacoes/publicacoes_sei/bahia_analise/sep/pdf/sep_70/aeroportos/pdf, acessado em 20/12/07.

Alves, C.J.P. - Uma metodologia para dimensionamento e avaliação de terminais de passageiros em aeroportos brasileiros. Tese de Mestrado, Universidade de São Paulo, 1981.

ALVES, C.J.P. \& MENDES, F. (1993). Uma técnica automatizada para orientação de pistas de pouso. Revista de Transporte e Tecnologia, Ano V, n.10, pp 27-34, 1993.

Coelho, R. e Nascimento, R., 2001, Aviação Civil e Regulação Econômica: Considerações Sobre a Agência Nacional de Aviação Civil - ANAC, Archétypon, v. 9, nº 25, Rio de Janeiro: UCAM.

DA SILVA, Adyr. Aeroportos e Desenvolvimento. Rio de Janeiro: INCAER/VILLA RICA, 1991.

De Neufville, R. - Airport Systems Planning. MIT Press, 1976.

Deutsche Lufthansa AG. Environmental Report Balance 1998/1999, Frankfurt, 1999.

Fares, A. T., 2007, Novo Panorama de Responsabilidade Civil no Transporte Aéreo, Revista Brasileira de Direito Aeronáutico e Espacial.

Grossi, V., 2000, Aviação Civil e Transição do Atual Modelo, Revista Brasileira de Direito Aeroespacial.

HARPER, George R. La Convención de Chicago de 1944 y la Política de Cielos Abiertos. In AVIAGLOBAL: artigo, 18 fev. 2004. Disponível em: htpp://www.aviaglobal.com. Acesso em 13 jan. 2007.

Horonjeff, R. \& McKelvey, F. X. - Planning and design of airports. McGraw-Hill, N.Y., 1994.

IATA. - Capacity evaluation study - airport terminal facilities. Canada, IATA, 1975. p.1-27.

ICAO, Advisory Circular és da circular $\mathrm{n}^{\circ}$ 269-AT/110, International Civil Aviation Organization

ICAO (1987). Airport planning manual. Part 1 - Master Planning, Second Edition.

INSTITUTO DE AVIAÇÃO CIVIL. Estudo básico para a internacionalização de Aeroportos de apoio à aviação sub-regional no Mercosul. Rio de Janeiro: maio, 1999.

International Air Transport Association. Airline Marketing - Self Teach Course, Montreal Geneva, 1992. 
Lelles, Léa (2001). Mercado do Transporte Aéreo Brasileiro: o Papel do Sistema Hub and spoke. Monografia de Especialização, Publicação E-TA01A/00, Centro de Formação de Recursos Humanos em Transportes, Universidade de Brasília, Brasília, 96 p.

Lessa, A., 2002, Atrativos para Empresas Aéreas se Organizarem em Hub and Spoke, Pós Graduação em Logística Empresarial, Fundação Getúlio Vargas - RJ.

Mançores, P. J., 2004, Análise da Influência do 11 de Setembro e da Taxa de Câmbio Sobre o Transporte Aéreo Internacional de Passageiros no Brasil, home page http://www.fae.edu/publicacoes/pdf/art_cie/art_06.pdf, acessado em 10/01/2008.

Medeiros, A. G. M. - Um método para dimensionamento de terminais de passageiros em aeroportos brasileiros. Tese de Mestrado, Instituto Tecnológico de Aeronáutica, 2004.

MOUSA, R. M. (2001). Integrated model for optimizing orientation of two-runway configuration.Jounal of Transportation Engineering. Vol 127, n.4 (ISSN 0733-947X) ICAO (1999). Aerodromes. Annex 14.

Mumayiz, S.A. - Overview of airport terminal simulation models. Transportation Research Record 1273-TRB, pp 11-20, 1990.

Neves, M. L., Artigo Revista Época - 07/12/2007 - 19:01 | Edição nº 499 (Cap. 6).

Oliveira, A. V. M., 2007, A Experiência Brasileira na Desregulamentação do Transporte Aéreo: Um Balanço e Propositura de Diretrizes para Novas Políticas, Núcleo de Estudos em Competição e Regulação de Transporte Aéreo - NECTAR.

Paes, André Leitão. Guerra no Ar; Em busca do Lucro Máximo -Projeto de Fim de Curso Eng. Produção UFRJ, Rio de Janeiro, 1999.

Palhares, G. L. \& Espírito Santo Jr., R. A., 2001, A Importância do Transporte Aéreo e seu Potencial para o Turismo Doméstico Brasileiro, Lições do Turismo 1, pág. 9-25, Rio de Janeiro, Editora UniverCidade.

Pasin, J. A. B. \& Lacerda, S. M., 2003, A Estruturação do Setor Aéreo e as Alternativas para Aviação Comercial no Brasil, Revista do BNDES, v. 10, nº 19, pág. 217-240.

Pereira, Ajalmar de Araujo. Planejamento de Linhas Aéreas - IAC, São José dos Campos, 1993.

PORTO, Manuel C. Lopes. Lições de Teoria da Integração e Políticas Comunitárias. Coimbra, Almedina, 1997.

POTENZE, Pablo Luciano. Historia Del transporte Aerocomercial. Buenos Aires: ALADA/UADE, 1997.

Quintas, H. \& Martins, A., 2002, Direito dos Transportes: Legislação Nacional, Internacional e Comunitária - Jurisprudência Nacional e Comunitária. 
RIBEIRO, Luciano R. Melo. Traçando os Caminhos dos Céus: O Departamento de Aviação Civil - DAC 1931 - 2001. Action Editora: Rio de Janeiro, 2002.

RODRIGUES, Gualdino. As fontes internacionais do Direito Aéreo: a situação da legislação sobre a aviação civil em Portugal. Lisboa: Dislivro, 2003.

Roland Berger \& Partner - International Management Consultants. Network Management Tools, Frankfurt, 1998.

SILVA, Flademir Candido da Silva. 2004. transporte aéreo no Mercosul: da Origem da Normativa Internacional ao Rumo de uma Política Comum Regional. Dissertação (Mestrado em Direito Negocial) - Universidade Estadual de Londrina, Paraná.

SILVEIRA, Expedito Albano da. A Globalização e os Acordos Bilaterais. SBDA: revista n80, Rio de Janeiro, 2000. Disponível em: <htpp://www.sbda.org.br>. Acesso em 19 jan. 2007.

SOUZA, C. A. F. (2003). Controle do perigo aviário nos aeroportos pela gestão dos fatores de atração de aves. Dissertação de mestrado. UnB, Brasília.

SOUZA, C. A. F. (2001). Procedimentos de Gestão Ambiental em Aeroportos. Publicação ETA02A/2001, UnB, Brasília.

Special Report 215 - Measuring Airport Landside Capacity. TRB, National Research Council, Washington,D.C., 1987,51-140.

Strongman, A.J. - Guidelines and priorities for the design of small domestic airports. ICAO Bulletin, Montreal, jan 1980.

Takacs, L. - Introduction to the Theory of Queues. Oxford University Press, NY, 1962.

htpp://pt.wikipedia.org/wiki/aeroporto_internacional_de_5\%c3\%A3o_paulo-guarulhos, acessado em 26/02/08. 